\title{
CRACOW CLEAN FOSSIL FUELS AND ENERGY EFFICIENCY PROGRAM
}

\section{FINAL REPORT}

\author{
T. Butcher, Editor
}

June 2001

Prepared by:

Biuro Rozwoju Krakowa S.A.

and

Brookhaven National Laboratory

Prepared for:

Office of Fossil Energy

U.S. Department of Energy

Washington, DC 20585 
BNL- 52632

FORMAL REPORT

\title{
Cracow Clean Fossil Fuels and Energy Efficiency Program
}

\author{
Final Report
}

Prepared by

Biuro Rozwoju Krakowa S.A.

and

Brookhaven National Laboratory

June 2001

Prepared for:

OFFICE OF FOSSIL ENERGY

U.S. DEPARTMENT OF ENERGY

WASHINGTON, D.C. 20585

\author{
ENERGY RESOURCES DIVISION \\ ENERGY SCIENCES \& TECHNOLOGY DEPARTMENT \\ BROOKHAVEN NATIONAL LABORATORY \\ BROOKHAVEN SCIENCE ASSOCIATES \\ UPTON, LONG ISLAND, NEW YORK 11973 \\ UNDER CONTRACT NO. DE-AC02-98CH10886 \\ UNITED STATES DEPARTMENT OF ENERGY
}




\section{DISCLAIMER}

This report was prepared as an account of work sponsored by an agency of the United States Government. Neither the United States Government nor any agency thereof, nor any employees, nor any of their contractors, subcontractors or their employees, makes any warranty, express or implied, or assumes any legal liability or responsibility for the accuracy, completeness, or any third party's use or the results of such use of any information, apparatus, product, or process disclosed, or represents that its use would not infringe privately owned rights. Reference herein to any specific commercial product, process, or service by trade name, trademark, manufacturer, or otherwise, does not necessarily constitute or imply its endorsement, recommendation, or favoring by the United States Government or any agency thereof or its contractors or subcontractors. The views and opinions of authors expressed herein do not necessarily state or reflect those of the United States Government or any agency thereof.

Available electronically at-

http://www.doe.gov/bridge

Available to U.S. Department of Energy and its contractors in paper from-

U.S. Department of Energy

Office of Scientific and Technical Information

P.O. Box 62

Oak Ridge, TN 37831

(423) 576-8401

Available to the public from-

U.S. Department of Commerce

National Technical Information Service

5285 Port Royal Road

Springfield, VA 22131

(703) 487-4650

8 Printed on recycled paper 


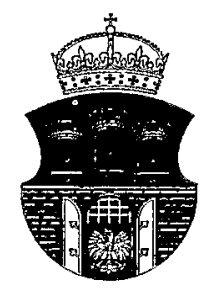

\title{
PREZYDENT MIASTA KRAKOWA \\ exndrej Ofotas
}

\author{
Mr Loren L. Schulze \\ United States Agency \\ for International Development \\ Bureau for Europe and the New Independent States
}

In the 1980 s, Kraków was a place of highest concentrations of air pollutants emitted, to a large extent, from local sources such as coal-fired home stoves and boiler houses.

The undertaking of activities aimed to eliminate these low emission sources was made possible by the 1989 decision of the United States Congress which allocated a US\$ 20 million aid package towards this purpose. In the preparation and implementation of the Cracow Clean Fossil Fuels and Energy Efficiency Program the leading role was assumed by US institutions: US Agency for International Development provided funds while US Department of Energy was managing the entire program. The main contractor was Brookhaven National Laboratory which, in close cooperation with Polish experts, conducted numerous projects and studies.

The program of reduction of low emissions was implemented in Krakow during the period 1991-2000. The objective of the program was to plan a strategy for reducing low emissions and to implement capital projects contributing to a maximum improvement of air quality, utilizing the available funds in the most cost-effective way. Owing to the great commitment and high professionalism of its participants, the program was an undeniable success. Under the program, more than 300 environmental projects were completed by US and Polish companies, providing the best measure of its achievements. Throughout the duration of the program, 75 per cent of local boiler houses and 20 per cent of home stoves were eliminated. We have noted with satisfaction how air quality has improved over the last decade: the average annual concentrations of pollutants have decreased by 50-60 per cent, approaching the permissible limit values.

On behalf of the authorities and residents of the city I would like to express cordial thanks to all persons and institutions participating in the implementation of the program. By their longterm effort and full commitment they have all contributed to the environmental improvement in this city. We hope that the experience gained and contacts established in the course of the program will enable a continuation of co-operation between the city of Krakow and US institutions and companies.

Cracow, January 2001

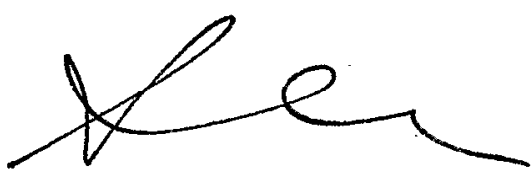




\section{TABLE OF CONTENTS}

Page

List of Abbreviations and Terms............................................... v

ACKNOWLEDGEMENTS.......................................................... viii

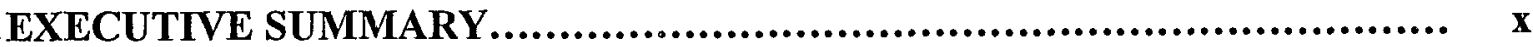

1. Introduction............................................................ 1-1

1.1 Cracow - A Highly Polluted City................................. 1-1

1.2 Program Organization............................................... 1-2

1.3 Scope of Work......................................................... 1-2

1.4 Schedule................................................................. 1-4

1.5 Budget................................................................ 1-6

2. Phase I Studies.......................................................

2.1 Objective and Scope of Phase I.................................. 2-1

2.2 Home Stoves............................................................ 2-1

2.3 The Solid Fuel-Fired Boilers..................................... 2-3

2.3.1. Database on Boiler Houses................................. 2-3

2.3.2 Fixed Grate Boilers............................................ 2-4

2.3.3 Stoker-fired Boiler.......................................... 2-6

2.4 Energy Conservation Demonstration Project....................... 2-8

3. Phase II Projects..........................................................

3.1 Control Techtronics International, Inc. .......................... 3-1

3.2 Honeywell, Inc...................................................... $3-3$

3.3 Shooshanian........................................................ 3-7

3.4 LSR Technologies................................................. $3-8$

3.5 Tecogen............................................................. 3-14

3.6 EFH Coal Company.................................................. $3-15$

3.7 TCS, Inc. .......................................................... $3-15$

3.8 Acurex Environmental Corporation................................ 3-15

4. Implementation Plan for Reduction of Low Emission Sources in Cracow... 4-1

4.1 Analytical Tools.................................................. $4-1$

4.1.1 Boiler House and Buildings Data Bases....................... 4-1

4.1.2 Geographical Information System as a Planning Tool....... 4-2

4.1.3 Spreadsheet Model to Compare Technical Options........... 4-3 


\section{TABLE OF CONTENTS}

Page

4.2 Implementation Plan................................................ 4-4

4.3 Recommendations for the City Authorities.......................... 4-8

5. Implementation of Phase IV .............................................. $5-1$

5.1 Conversion of Solid Fuel-Fired Boiler Houses......................... 5-1

5.1.1 Description of the Project......................................... 5-1

5.1.2 Scope of Work..................................................... 5-4

5.1.3 Project Implementation....................................... 5-5

5.2 Modernization of the Heating System Management in Children's Hospital.......................................................... 5

5.2.1 Description of the Current Status.............................. 5-7

5.2.2 Scope of Work................................................ 5-9

5.2.3 Project Implementation.................................... 5-9

$5.3 \quad$ Elimination of Coal Stoves........................................ $\quad 5-10$

5.3.1 Description of the Current Status............................... 5-10

5.3.2 Scope of Work.................................................. 5-11

5.3.3. Project Implementation.................................... $\quad 5-12$

6. Effect of the Program Implementation........................................ 6-1

6.1 Reduction of Pollutant Emissions...................................... 6-1

6.2 Program's Impact................................................. 6-1

6.2.1 Program for Reconstruction and Modernization of the District Heating Network.................................... 6-2

6.2.2 Program to Restrain the Decline in Thermal Energy Demand and to Reconstruct the Market of Cracow Heat And Power Plant S.A. ....................................... 6-2

6.2.3 Elimination of Boiler Houses by Private Owners............... 6-3

6.2.4 Activity of Environmental Protection Funds................. 6-4

6.2.5 Energy Conservation Programs............................... 6-4

6.3 Improvement of Air Quality in Cracow............................... 6-4

7. Plans for the Future......................................................... 


\section{TABLE OF CONTENTS}

Page

7.1 State Environmental Policy in the Years: $1991-2000 . . . . . . . . . . . . . .7-1$

7.2 Greater Participation of Society in Environmental Protection Policies................................................................ 7-3

7.3 Cooperation of the Polish and American Companies................. 7-4

7.4 Continuation of Activities in Cracow.................................... 7-6

7.5 Programs in the other parts of Poland.................................. $\quad 7-11$

8. Summary Statement...................................................... 8-1

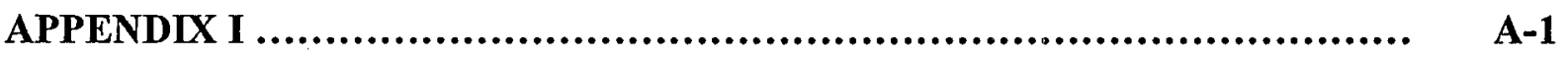




\section{LIST OF FIGURES}

Page

Figure E-1 Typical Hand-fired coal boiler - an example of Cracow's Low Emission Sources...................................................... viii

Figure E-2 Photo of LSR Core Separator Installation in Poland................. xii

Figure E-3 Illustration of the elimination of solid fuel fired boiler houses

In Cracow over the term of this program............................. xvii

Figure 1-1 The historic market square in Cracow................................... 1-1

Figure 1-2 Program Organization.............................................. 1-3

Figure 2-1 Typical coal stove.................................................... 2-2

Figure 2-2 Typical Cracow apartment building................................ 2-8

Figure 3-1 Results of installation of CTII controls at Balicka..................... 3-2

Figure 3-2 Simple illustration of the LSR Core Separator System................. 3-9

Figure 3-3 Typical core separator arrangement................................. 3-10

Figure 3-4 Trend in installed capacity of Core Separators in Poland 1995-1998. 3-11

Figure 3-5 Photo of Core Separator Installation in Poland........................ 3-11

Figure 4-1 Example use of the Geographic Information System (GIS) to show locations of local heating boilers around the city center....... 4-3

Figure 5-1 Typical coal-fired boiler house with stoker firing..................... 5-1

Figure 5-2 Stoker fired boiler. Coal chute, moving grate, and drive............. 5-2

Figure 5-3 Hand-fired coal boiler and typical heat exchanger station which replaced it.......................................................... $5-3$

Figure 5-4 New gas-fired boiler room........................................... $5-4$

Figure 5-5 Entrance to the Polish-American Children's Hospital................ 5-7

Figure 6-1 Illustration of the elimination of solid fuel-fired boiler houses

In Cracow over the term of this program.......................... 6-3

\section{LIST OF TABLES}

Page

Table 3-1 List of Sites In Poland Where the LSR Core Separator

Has Been Installed.................................................. 3-12 \&

Table 6-1 Summary of Environmental Impacts................................ 6-2 


\section{List of Abbreviations and Terms}

Throughout this report there are many abbreviations as well as expressions which may not be familiar to readers of the English version of this report. These are listed here with some discussion.

$\begin{array}{ll}\text { AID } & \text { U.S. Agency for International Development } \\ \text { BSC } & \text { Bilatcral Stecring Committce } \\ \text { BNL } & \text { Brookhaven National Laboratory } \\ \text { BRK } & \text { Biuro Rozwoju Krakowa, or Cracow Development Office, the } \\ & \text { main organization in Cracow involved with this program } \\ \text { DHS } & \text { District Heating System } \\ \text { DOE } & \text { U.S. Department of Energy } \\ \text { duf } & \text { inexpensive, fine coal } \\ \text { ECK S.A. } & \text { Elektrocieplownia Krakow SA - the Cracow Combined Heat and } \\ & \text { Power Plant } \\ \text { ESCO } & \text { Energy Savings Company } \\ \text { Gmina } & \text { Municipality } \\ \text { GFOSiGW } & \text { Municipal Fund for Environmental Protection and Water } \\ & \text { Management } \\ \text { MPECS.A. } & \text { Miejskie Przedsiebiorstwo Energetyke Cieplnej s.a. - the Cracow } \\ & \text { District Heat Utility } \\ \text { Voivodship } & \text { Province } \\ \text { SEED } & \text { Support for Eastern Europcan Dcmoncracy Act of 1989 } \\ \text { NETL } & \text { National Energy Technology Laboratory (DOE) } \\ \text { FEWE } & \text { Polish Foundation for Energy Efficiency } \\ \text { MAES } & \text { Małopolski Agency of Energy and Environment } \\ \text { ZEK S.A. } & \text { Cracow Power Supply Utility } \\ \text { MPK } & \text { Polish National Bus Transportation Company }\end{array}$

\section{NOTE ON FUEL HEATING VALUES AND THE THERMAL EFFICIENCY OF BOILERS AND STOVES}

In the U.S. it is customary to use the higher heating value (HHV) of a fuel, while in Poland (and Europe, generally) lower heating value (LHV) is used. The difference between these is the latent heat of water vapor in the products of combustion. The HHV credits the fuel with this latent heat, while the LHV does not. These two heating values can be related by:

$$
\mathrm{LHV}=\mathrm{HHV}-10.30\left(\mathrm{H}_{2} \times 8.94\right)
$$

Where $\mathrm{H}_{2}$ is the total percent hydrogen in the fuel.

In this report, in various places, the efficiency of boilers and furnaces is discussed. In the test program conducted as part of this work, these efficiencies were determined using a heat-loss 
method. When LHV is used for fuel heating value energy loss due to the latent heat of water vapor in combustion products is not considered in the efficiency calculation. This is the normal Polish procedure and was used for all efficiency calculations included in this report. The customary U.S. procedure uses HHV and includes the latent heat loss. Efficiencies listed in this report are higher than would be realized with the customary U.S. method. The magnitude of the difference depends on the fuel but for most solid fuels described here, it can be estimated at 3 efficiency percentage points. 


\section{ACKNOWLEDGMENTS}

The work summarized in this report represents the combined efforts of many organizations both in Poland and the United States. Because of the project's size and the complex relationships between participating organizations, it is very difficult to give proper credit to all of the participants. In addition to the companies directly involves with the Phase III and IV projects as described in this report, the following organizations made significant contributions to the work during the course of the program:

Polish Organizations:

Academy of Mining and Metallurgy

CitiProf

Ekopol

FEWE-Cracow

Cracow Development Office (Biuro Rozwoju Krakowa, BRK S.A.)

Cracow Polytechnic Institute

Naftokrak-Naftobudowa

National Business Services Holding of Poland Ltd.

Polish American Children's Hospital

Polinvest Ltd.

Tawimex

VRG Strategy Company Ltd.

U.S. Organizations:

Brookhaven National Laboratory

Burns and Roe Company

Burns and Roe Services Corp.

Electrotek Concepts, Inc. (Lawrence Markel)

G. Reeves Associates

Pacific Northwest Laboratory

Pittsburgh Energy Technology Center (now - National Energy Technology Center)

Most of the project activities undertaken in Poland were done under direction of Biuro Rozwoju Krakowa, BRK S.A. President Jan Bieda of BRK played a key role in managing these efforts. Key leadership at BRK was also provided by Andrzej Łazęcki and Marzanna Schnotale.

As discussed in Chapter 1 of this report, a Bilateral Steering Committee was organized to oversee all of these efforts. Members of this committee during the project period include:

Howard Feibus, U.S. Department of Energy

Jan Friedberg, Deputy Mayor, City of Cracow

Krzysztof Görlich, Deputy Mayor, City of Cracow

Robert Ichord, U.S. Agency for International Development

Stanisław Kaminski, Deputy Director, Ministry of Environmental Protection, Natural Resources and Forestry 
James Lacy, U.S. Department of Energy

Leonard Rogers, U.S. Agency for International Development

Joseph Strakey, U.S. Department of Energy

Jerzy Wertz, Director, Cracow Office of Environmental Protection

Loren Schulze, U.S. Agency for International Development

Pawel Zorski, Deputy Mayor, City of Cracow

Jerzy Meysztowicz, Vice-Voivode of Malopolska Region

Douglas Jewell, U.S. Department of Energy

Andrzej Pęcikiewicz, U.S. Agency for International Development

Maryla Jakubowicz, U.S. Agency for International Development

Funding for this project was provided by the U.S. Agency for International Development (U.S. AID); through the U.S. Department of Energy (U.S. DOE) under Interagency Agreement. At $\mathrm{AID}$, leadership for this program was provided by Dr. Robert Ichord, Leonard Rogers, and Dr. Loren Schulze. At DOE the program was managed by the Office of Fossil Energy with direct management by the Pittsburgh Energy Technology Center (PETC) which later became a part of the National Energy Technology Laboratory (NETL). The program benefited from leadership provided at DOE by: Dr. Howard Feibus, Dr. Joseph Strakey, Douglas Gyorke, and Douglas Jewell. We would also like to thank the U.S. Consulate in Cracow for critical support throughout the program. A great deal of support was also provided by the U.S. AID office in Warsaw. As discussed in Chapter 1, work in energy conservation was done through Pacific Northwest Laboratories. Mr. Lawrence Markel, formerly of Electrotek Concepts, contributed directly to the energy conservation part of the work and enthusiastically helped with many other aspects of the program.

The editors would also like to acknowledge the major role played by the Cracow district heat distribution utility Miejskie Przedsiębiorstwo Energetyki Cieplnej w Krakowie (MPEC) throughout the entire program. The editors would also like to thank the Spóldzielnia Mieszkaniowa "Krowodrza" housing cooperative, which acted as host site for the energy conservation demonstration, in Phase I. We would also like to acknowledge critical assistance provided by Tadeusz Kasprzyk and his team at the Cracow Combined Heat and Power Plant (ECKSA).

We would also like to mention the contributions of Tadeusz Piekarz, Cracow Voivode at the critical formation stage of this program. He provided very important insight and a framework for cooperation that endured for the entire program.

A major contribution to this program was also made by the very talented and patient translators. Special mention must be made of Dr. Roman Tertil of Letterman Translators and Interpreters, a true friend of this program. We would also like to make a special thank you to Dr. Piotr Wandzilak of Render Translators and Interpreters.

Acknowledgements should also be made for the contributing technical staff at BNL, some of whom gave up a great deal of personal time for the work. This includes Ms. Barbara Pierce, who lead much of the economic analysis work, Richard Krajewski, Jerome LaMontagne, and Dr. C. R. Krishna. The BNL contracts and administrative staff also made important contributions in 
rapidly maneuvering through several challenging issues. This includes: Mike Furey, Anthony Salvo, Kevin Fox, Anthony Guadagni; B.J. Carreras, Bonnie McGahern, and Richard Melucci.

Finally, preparation of the English version of this report would not have been possible without the patient and capable support from Gail Brown. 


\section{EXECUTIVE SUMMARY}

\section{Introduction}

Cracow, the largest city in the south of Poland and the former capital of Poland, is situated on the banks of the Vistula River. It is a city of around 741,000 residents and 327 square kilometers, is one of the largest centers of higher education in Poland, and is an outstanding cultural and artistic center.

In 1980, Cracow had severe air pollution problems which were caused by industrial emissions, the influx of pollutants from other regions and by small coal stoves and boilers -"low emission sources". A 1991 inventory indicated that within the city limits, there were 1,133 solid fuel-fired boiler houses with a combined installed capacity of $965 \mathrm{MW}$, approximately 100,000 coal-fired home stoves and 17,000 spaces where heat was supplied from small home boilers using solid fucl. The pollution originating from these heating installations is termed "low emissions". It is estimated that in the 1980s, low emission sources contributed $35-40 \%$ of the total pollution, resulting in the highest concentration of pollutants in the center of Cracow.

In 1989, the U.S. Congress adopted the Support for East European Democracies (SEED) Act which directed the U.S. Department of Energy (DOE) to cooperate with the American and Polish experts to

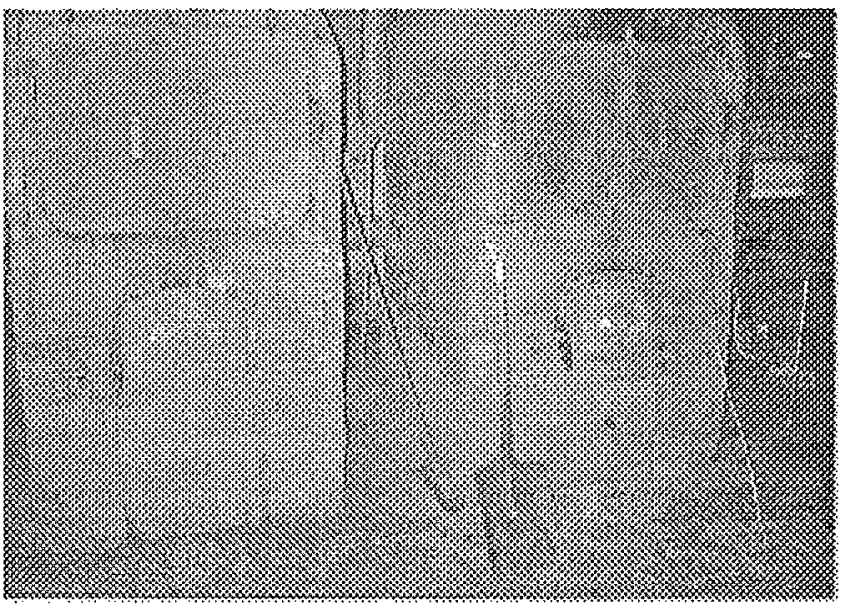

Figure E-1 . Typicall Hand-fired coal boiler - an example of Cracow's Low Emission Sources. undertake an assessment program in Poland to use fossil fuels cleanly in small-scale combustion equipment. The program became specifically directed toward the emissions problems of low emission sources (coal home stoves and solid fuel-fired boiler houses) in Cracow. A total budget of 20 million dollars was allocated. Oversight of this program has been provided by the U.S. Agency for International Development (U.S. $\mathrm{ATD}$ ) and the program has been implemented by DOE in cooperation with various Polish and American institutions and companies. In 1991, U.S. and Polish officials signed a Memorandum of Understanding formally initiating and directing the Cracow Clean Fossil Fuels and Energy Efficiency Program.

\section{Program Organization}

In 1991, USAID and USDOE signed an interagency agreement to conduct the project. Representatives from both organizations worked with Polish officials to establish an 
eight-member Bilateral Steering Committee (BSC) to plan and oversee the Program. In 1991, U.S. and Polish officials signed a Memorandum of Understanding formally initiating and directing the Cracow Clean Fossil Fuels and Energy Efficiency Program.

Developing a program approach for the most effective use of the available funds required considerable effort on the part of all project participants. The team recognized early that the cost of solving the low emissions problem even in only one city far exceeded the amount of available U.S. funds. Economic conditions in Poland limited availability of local capital funds for environmental projects. Imposing environmental costs on struggling companies or city residents under the difficult conditions of the early 1990's required careful consideration of the economic and political impacts. For all of these reasons the program sought to identify technologies for achieving air quality goals which, through improved efficiency and/or reduced fuel cost, could be so attractive economically as to lead to self-sustaining activities beyond the end of the formal project.

The effort under this program has been focused into 5 main areas of interest as follows:

1) Energy Conservation and Extension of Central Station District Heating. Conserving energy and installing energy-efficiency measures reduce the load and emissions from boiler houses or make more heat available for expanding the district heating system. Extending the central station district heating system would climinate local boiler houses in favor of heat supplied by more efficient, less-polluting co-generation plants.

2) Replacement of Coal- and Coke-Fired Boilers with Natural Gas-Fired Boilers.

3) Replacement of Coal-Fired Home Stoves with Electric Heating Appliances.

4) Reduction of Emissions from Stoker-Fired Boiler Houses. Many local boiler houses are relatively new or are far from existing district heating lines. These boiler houses will not be replaced or eliminated, but there are numerous alternatives to increase their efficiency and reduce their emissions.

5) Reduction of Emissions from Coal-Fired Home Heating Stoves. Due to economic considerations, it is likely that many coal-fired home heating stoves will remain for some time. Therefore, this Program also explored ways to reduce emissions from existing stoves.

The Bilateral Steering Committee defined four phases for the Program:

Phase I was a stage of analyses, tests and design studies. Data on the sources of low emissions was to be collected and possible options for reduction of pollution explored. For each of the options, technical tests of equipment were completed in order to assess potential reductions in emissions, together with an economic analysis evaluating the cost of implementation. The Phase I work included a demonstration project on building energy efficiency measures, analysis of air quality, public opinion surveys, test results analysis and the analysis of options selected. 
In Phase II Polish and U.S. companies were informed of the Program, the results of the work done in Phase I, and the opportunities available in Phase III.

Phase III involved joint implementation, by American and Polish companies, of projects selected through an open solicitation announced by DOE in December, 1992. The solicitation was aimed at identifying U.S. technologies that could be used, in cooperation with Polish organizations, to achieve the program goals. The objective of Phase III was to promote technologies improving air quality, attractive enough economically to enable their further application after the conclusion of the Progrann. All projects are discussed in more detail below.

Phase IV included the development of a long term strategy for the elimination of boiler houses and home stoves (Phase IV a) and the implementation of projects (Phase IVb) covering three groups of activities:

- Elimination of solid fuel fired boiler houses through conversion to gas or through connection to the district heating system;

- Modernization of the entire heating system in the Children's Hospital of the Collegium Medicum of the Jagiellonian University;

- Elimination of home stoves.

The projects have been implemented with cost sharing provided by the boiler house owners or by "third party investors". The American funds were allocated for use in the preparatory and design works and for the purchase of the basic equipment.

The time schedule of the Program was as follows:

Phase I

1991-1995

Phase II 1992

Phase III

1993-1996

Phase IV a

1996-1997

Phase IV b

$1998-2000$

Most of the work in Poland was done under the local direction of the Cracow Development Office - Biuro Rozwoju Krakowa S.A. or "BRK".

\section{Phase I Studies}

Work during Phase I included: source performance testing, a building energy conservation demonstration, engineering analysis to develop option costs, a public opinion survey, incentives analysis, and options comparison. 
Testing measured emissions and performance from equipment and fuels that are presently used, as well as alternative equipment and fuels considered as potential improvements. Engineering analysis estimated costs for promising alternatives and conducted feasibility studies and conceptual designs for implementing these alternatives. As part of the engineering analysis, the impact was studied of selected options on air quality in the city. The incentives analysis tasks recommended financial incentives or regulatory changes necessary to convince residents and boilcr owners to invest in alternatives that will reduce emissions. These incentives were based on detailed analyses of the economics of specific options to energy users. Complimenting these economic studies, public opinion was surveyed to evaluate the willingness and ability of residents to contribute to the costs of reduced pollution.

During this program, a demonstration of low-cost weatherization and other conservation techniques was done on four, identical, two-story buildings in a Cracow cooperative. The demonstration showed that the weatherization package, improved controls, and roof insulation were very cost-effective. Energy savings as high as $32 \%$ were realized. Reduced energy consumption in existing buildings makes more district heat system capacity available for the elimination of local, coal-fired boilers.

Primary Phase I conclusions are as follows:

1. While low emission sources are important, particularly in the city center, even their complete elimination would not fully solve the city's air pollution problems.

2. Coal-fired stoves have the highest emission factors but are the most difficult to eliminate

3. Attractive options for pollution reduction include:

- conversion from local solid fuel boilers to the district heating system;

- conversion to natural gas;

- use of improved fuels; and

- improved operations.

4. The potential for improved energy conservation in buildings is very large.

5. Excess capacity in the district heating system would allow more than half of the existing boiler houses to be eliminated by connecting them to the municipal district heating network.

\section{Phase III Projects}

The objectives of the work done in Phase III were to provide assistance in reducing pollution caused by low emission sources and the creation of joint-venturcs to promote sustainable activities which would provide benefits beyond the end of the program. As a result of a solicitation conducted by the U.S. Department of Energy, eight American 
companies participated in Phase III, along with Polish partners. All American companies selected for the program provided $50 \%$ cost-share.

Each of the American companies cooperated with partners in Poland. The projects were completed with different degrees of success, but collectively have helped the American companies start businesses on the Polish market and made contributions to improved air quality in Cracow. A short discussion of each company follows:

Control Techtronics International Incorporated. CTII is a controls manufacturing firm based in Harrisburg, Pennsylvania. Under this project CTII introduced to the Polish market their advanced control technology for stoker-fired boilers. CTII worked together with the Municipal District Heating Company in Cracow (MPEC) and other Polish companies. Their work also involved Pennsylvania State University and Cracow Polytechnic University. Automatic control systems were installed at the MPEC Balicka boiler house. Prior to controls installation these boilers operated with very high excess air levels, leading to very low efficiency, particularly at low load. Installation of the controls led to dramatic improvements in both efficiency and particulate emissions.

Honeywell, Inc. Honeywell is a major worldwide controls manufacturer, established in Minneapolis, Minnesota in 1885. Its first European subsidiary began operation in 1934. Honeywell now operates in 95 countries, including Poland. The Honeywell project involved a complex modernization of the heating systems of the Balicka boiler house and the Bienczyce Housing Cooperative and the installation of controls in the boiler houses of the Jana Pawła II and Narutowicza Hospitals. Honeywell worked jointly with Cracow Heat and Power Plant (ECK S.A.) on replacing, by network connection, four major boiler houses (supplied heat exchanger substations and control system). The project has demonstrated that significant energy savings can be obtained both at the stage of heat production due to installation of combustion controls and at the customerside heat supply system, due to control of the heat amount supplied to the building (temperature reset control in heating nodes) and to the apartments (thermostatic valves). Honeywell continues on the Polish market with a strong presence.

Shooshanian Engineering Associates. Shooshanian Engineering Associates was founded in 1961 and is based in Boston, Massachusetts. Shooshanian is a mechanical and electrical engineering firm specializing in study, design, and construction services. Projects completed by Shooshanian in cooperation with its Polish partners focused on extension and improvements of the district heating

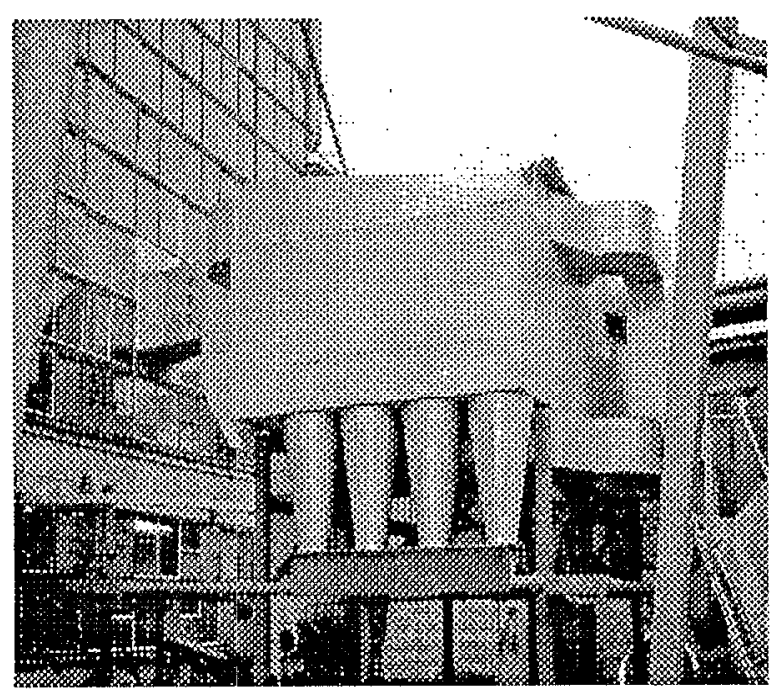

Figure E-2. Photo of LSR Core Separator Installation in Poland 
system, thus permitting elimination of the local coal- and coke-fired boiler houses through connections to the district heating network. Shooshanian provided to their Polish partners capabilities in a broad range of areas including: evaluation of candidate conversion projects, customer contract arrangements, marketing, organization of customer service, engineering design, and project management. During the course of this program Shooshanian was involved with the connection of 33 sites to the district heating system.

LSR Technologies. LSR Technologies, Inc. Of Acton, Massachusetts is a small company specializing in the development of advanced technology for physical and chemical separations. Under this project they introduced to the Polish market and advanced mechanical particulate control device - the Core Separator, for stoker-fired boilers. These provide far higher collection efficiency (95\%) as compared to existing cyclone collectors $(75 \%)$ and are much less expensive than fabric filters. LSR cooperated with EcoInstal of Poznan and transferred to them manufacturing capability for the Core Separators. Under this program this team installed these devices at two large sites in Cracow. Beyond the formal scope of this program, EcoInstal has completed 36 additional Core Separator system installations at industrial plants across Poland.

Tecogen. Tecogen is a consulting, research and engineering company from Boston, specializing in investment preparation and management, energy research and design. Under the Program, Tecogen worked on introducing to Poland a new technology for controlling and optimizing combustion processes in stoker-fired boilers. Another important contribution of Tegogen was development and implementation of shared savings agreements. Their boiler optimization work included: addition of a heat recovery unit to improve efficiency, automatic control system installation, flue gas recirculation, and improvements to the existing cyclones. The company completed the modernization of a large boiler house owned by the Housing Cooperative in Wieliczka. A substantial efficiency improvement was obtained and particulate and $\mathrm{SO}_{2}$ emissions were reduced below permissible standards.

EFH Coal Company. The largest investment proposed by the American companies was to be a coal cleaning facility constructed by the EFH Coal Company. To implement the project, EFH along with Polish partners established the ECOCOAL company. The company studied in detail site selection, market development, and process design. Phase I studies had shown that significant improvements in stoker-fired boiler performance could be realized with improved fuel of the type which would be produced. This project was not completed for two reasons. First, during the 1990's there was a rapid decline in coal use in stoker-fired boilers in Cracow due, in part, to other program activities. The second factor was delays in the project schedule due to permitting and other requirements. The Bilateral Steering Committee did not approve a requested time extension for the project and it was terminated.

TCS, Inc. TCS, Inc. proposed modernization of stoker fired boiler houses through the use of micronized coal technology. The equipment required for coal micronization must be installed in the boiler house premises and coal must be micronized before it is burned 
in high performance, pulverized coal burners. This technology has several benefits: more complete combustion, lower ignition temperature, and a reduction of the amount of slag produced during combustion. During the course of the project TCS cooperated with several candidate sites in developing conversions to this technology. In all cases, however, the conversion costs were too high to be acceptable on the Polish market. A decision was made by the Bilateral Steering Committee to terminate the project.

Acurex Environmental Corporation. Acurex Environmental Corporation proposed to produce smokeless briquettes for home stoves, based on company's proprietary technology. The briquettes would replace coal and reduce emission of pollutants by $70 \%$. This program included a testing/development phase during which Acurex worked to optimize briquette formulation for specific Polish components. The briquette price proposed by Acurex was not competitive compared to the local coal price and the company did not find a Polish a partner interested in its production. The Bilateral Steering Committee made a decision not to allow the Acurex project to be completed as originally planned.

\section{Development of a City Plan}

During the course of this program a long term strategy for addressing the low emission sources in Cracow was developed, primarily by BRK. To support this effort a number of tools for collecting, analyzing and presenting information on low emission sources were developed. This included:

- Boiler house database;

- Buildings database;

- Technical infrastructure database;

- Geographical Information System (GIS) for the graphic presentation of the above information on city maps of different types; and

- Spreadsheet models for comparison of various types engineering options.

In the development of the plan BRK studied specific regions of the city independently, identifying and evaluating technical options for solid fuel-fired boilers and home stoves. In some ways this work was a detailed extension of the options analysis done during Phase I. The most attractive options in general are replacement of hand-fired boilers with new gas-fired boiler or connection to the district heating system. Modernization of stoker-fired boilers, based on the Phase III project results, is also attractive. Less attractive, although important, is the elimination of home stoves through replacement with gas or electric heating.

As a result of this planning effort barriers to implementation of options and specific recommendation for City authorities were prepared. The key barriers include: limited 
resources of building owners; difficulties in obtaining financing for small projects; and inadequate electrical and gas distribution infrastructures. Specific recommendations include: support through municipal environmental funds; public information activities; promotion of cooperatives among building owners to organize block financing; regulations on coal quality as a transition measure; and promotion of building energy conservation.

\section{Phase IV Conversion Activities}

\section{Conversion of Solid Fucl-Fired Boiler Houses}

Small, hand-fired boilers using coal or coal-coke mixtures are in Cracow an very important part of the air pollution problem, particularly in the center of the city. Under this program assistance was directed towards the owners of the solid fuel fired boiler houses. The objective of the program was the elimination of the solid fuel-fired boiler houses through connection of the boiler houses to the district heating system or by conversion of the boiler houses to gas. The assistance was both organizational and financial in nature. The organizational assistance included: information activities, preparation of the technical documentation (design studies), obtaining building permits on behalf of the owner, submission of applications to the environmental funding organizations, help in selection of contractors, coordination of supplies, and technical supervision of investment implementation. Financial assistance included funding of the preparatory and design plans and purchase of the basic equipment required for the new heat source. The program was available to all boiler house owners, irrespective of their legal status.

The program provided $50 \%$ of the project costs and this was used for planning and design work and for the purchase of major equipment. The building owner was responsible for the balance of the project cost including auxiliary equipment and all installation work. The building owners practically had two ways to participate. In the first they could develop their own financing for their half of the project cost and in this case BRK provided assistance as needed with applications for financing. In the second, the building owners could commit to offers from "third party" investors. Under this arrangement the third party would provide the balance of the project funds, manage all construction work, remain as the owner of the installed heating equipment, and sell heat to the building owner. Both the Cracow District Heat Company (MPEC) and the Cracow Combined Heat and Power Plant (ECKSA) offered this arrangement to building owners.

During the course of this work 118 solid fuel-fired boiler houses were eliminated through conversion. Of these, 75 were replaced with new gas-fired equipment and 43 were connected to the district heating system. Of the 75 gas conversions, 35 were financed by individual building owners and 40 participated with third party investors. In the case of district heat connections, of course, all work was done by the third party investors. 


\section{Polish-American Children's Hospital}

Under this part of the program a major renovation of the heating system at the Children's Hospital of the Collegium Medicum of the Jagiellonian University was supported. This effort included the elimination of a large coal-fired boiler house near the hospital, which was a major local pollution source. Annual coal consumption displaced is 10,000 metric tons. The existing system for heating the hospital was inefficient, uneconomical and a source of pollution that had to be eliminated. The renovation work included: expanded use of heat from the district system, modernization of internal heat exchangers and control systems, installation of two new steam boiler houses and a new hot water boiler house on-site.

Most of the funding for this work was provided by MPEC, the Cracow District Heat Company. U.S. funds were used for planning and design work and to purchase some equipment including: piping, heat exchangers and controls, and auxiliary equipment for the new boiler houses.

\section{Elimination of Coal Stoves}

The objective of this effort was to decrease the number of coal-fired home stoves by converting them to electrical heating. Essentially, electric heating elements are refit into the existing massive tile stoves. The mass of the stoves is heated during "off-peak" periods. The effort was directed toward the city center, where the stove concentration is highest and ambient air pollution impacts severe.

Earlier projects considered the use of smokeless briquettes. These yield dramatic pollution reduction and have long been considered an attractive transition solution. Several attempts have been made to bring these to the market, however, have failed. Gas conversion could also be considered an option, but it is much less attractive economically than the electric conversion.

The key impediment to elimination of coal use in the stoves by electric conversion is the siting of required local transformers to provide needed capacity to the buildings. Problems include: lack of willingness of building owners to provide space for the transformer substations, unresolved legal status of buildings, and lack of funding available.

The work in this area was focused on identifying and developing projects for the installation of transformer substations. As a result of this work 4 favorable siting decisions were obtained. The Cracow Power Supply Utility has committed to implementing these projects.

\section{Effects of the Program}

This Program has directly resulted in the implementation of over 300 capital projects, with the participation of firms from the United States and Poland. The U.S. investement 
of $\$ 20$ million has been more than matched by investment on the Polish side. The total program investment is estimated to be $\$ 58$ million.

The program has, in addition, led to the development of a substantial base of engineering, legal, and organizational information. The Cracow Program provides a model for other Polish towns experiencing similar air pollution problems.

A summary of the programs environmental impacts is provided in the following table:

\begin{tabular}{|l|l|l|l|l|l|}
\hline \multirow{2}{*}{ Project } & \multicolumn{4}{|l|}{ Reduction of emissions } & \multicolumn{3}{l|}{} \\
\cline { 2 - 6 } & Particulates & $\mathrm{SO}_{2}$ & $\mathrm{NO}_{\mathrm{x}}$ & $\mathrm{CO}$ & $\begin{array}{l}\text { Equivalent } \\
\text { emissions }\end{array}$ \\
\cline { 2 - 7 } & $\mathrm{Mg} /$ year & $\mathrm{Mg} /$ year & $\mathrm{Mg} /$ year & $\mathrm{Mg} /$ year & $\mathrm{Mg} /$ year \\
\hline Shooshanian & 265.6 & 258.3 & 45.1 & 388.8 & 1353.7 \\
\hline Control Techtronics & 101.0 & 36.0 & -9.0 & 9.0 & 307.3 \\
\hline LSR & 22.8 & - & - & - & 66.1 \\
\hline Honeywell & 690.0 & 590.0 & 129.0 & 950.0 & 3440.0 \\
\hline Tecogen & 112.0 & 244.0 & 21.0 & 97.0 & 678.2 \\
\hline MPEC boiler house conversion 1998 & 39.7 & 21.6 & 1.7 & 55.9 & 169.7 \\
\hline 1999 boiler house conversion & 127.6 & 76.4 & 10.2 & 183.3 & 567.7 \\
\hline 2000 boiler house conversion & 230.3 & 231.7 & 61.8 & 415.7 & 1286.5 \\
\hline Children's Hospital & 168.6 & 128.0 & 36.3 & 99.5 & 772.2 \\
\hline Elimination of coal-fired home stoves & 13.6 & 7.6 & 0.7 & 68.0 & 83.0 \\
\hline Total & 1771.2 & 1593.5 & 296.8 & 2267.1 & 8724.5 \\
\hline
\end{tabular}

The total reduction in $\mathrm{CO}_{2}$ emissions due to all aspects of the program is estimated to be 67,645 metric tons per year.

In 1991, 1,133 solid fuel-fired boiler houses and approximately 100,000 coal fired home stoves were in operation in Cracow. The annual consumption of solid fuels was about 475,000 metric tons. Over the course of this program, the number of boiler houses using solid fuel decreased by $75 \%$ and the number of home stoves decreased by $22 \%$. The combined amount of solid fuel use dropped by about $70 \%$.

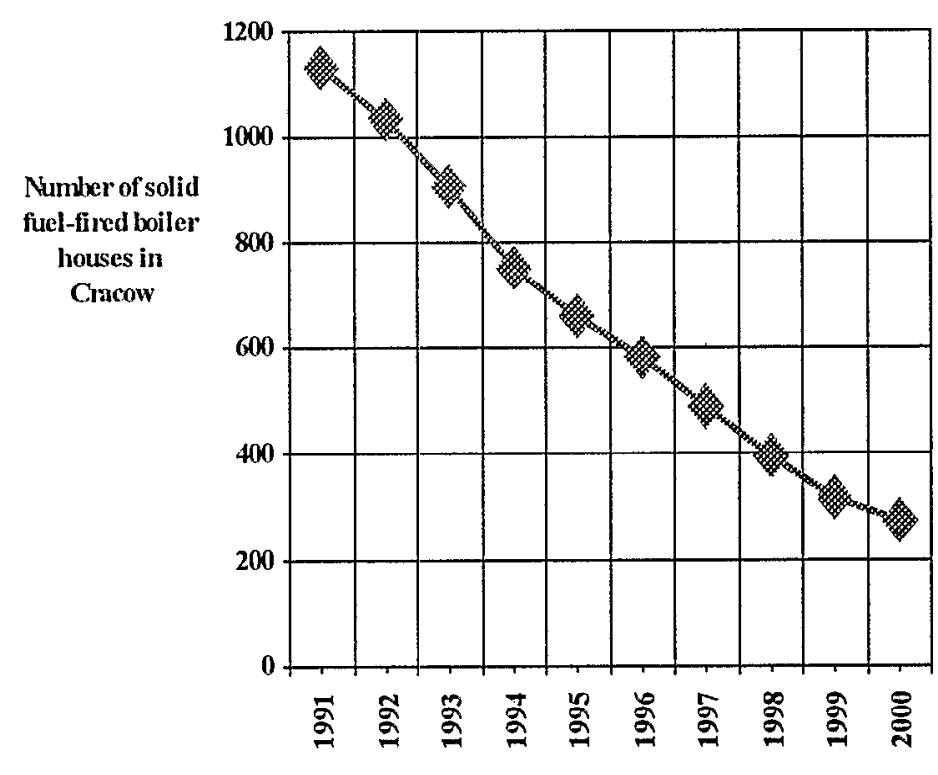

Figure E-3. Illustration of the elimination of solid fuel-fired boiler houses in Cracow over the term of this program. 
At the end of the $1980 \mathrm{~s}$, the mean annual concentration of suspended particulates was over $100 \mu \mathrm{g} / \mathrm{m}^{3}$ which exceeded the permitted level by a factor of two (in the heating season - three times), whereas $\mathrm{SO}_{2}$ exceeded the permitted level as much as 3.5 times. Measurements indicate steady improvement in air quality. From 1989 to 1998, the mean annual concentrations of suspended particulates decreased by more than $50 \%$, stabilizing at a level below the permissible standard. In the heating season, the permissible concentrations levels are exceeded only slightly. In the same period, the mean annual concentration of $\mathrm{SO}_{2}$ dropped by almost $60 \%$, and in 1998 it reached a value lower than the permissible value for the first time ever. Also in the heating season, the concentrations of $\mathrm{SO}_{2}$ do not exceed the permissible value. Particularly noticeable is the reduction of air pollution in the center of town where the concentration of suspended particulates dropped by almost $60 \%$, and the concentration of $\mathrm{SO}_{2}$ dropped by $65 \%$.

\section{Plans for the Future}

Environmental laws and policies in Poland have evolved considerably over the past decade. The nation remains committed to the environment through two key principles: balancing social, environmental, and economic needs during development, and greater participation of the public in environmental matters. These principles have led to many specific actions including: environmental laws, formation of new agencies, support for organizations related to energy efficiency and environment, funding support on different levels, and increased international cooperation.

The City of Cracow has an aggressive program for continuing this work. A draft plan has been developed for the supply of heat, electricity and gas and this builds on planning work done under this program. A plan of compensated development and environmental protection is currently under development, which will define a strategy of the city for implementation of the environmental policy. To implement energy efficiency programs in buildings, an Energy Saving Company (ESCO) has been formed. A program of lighting modernization is being carried out. The Malopolska Agency of Energy Saving and Environmental Protection, which will be responsible for initiation and implementation of energy efficiency and environmental protection programs has been established. This agency will implement the concept of balanced development in the Malopolska Region and City of Cracow through the initiation and implementation of programs supporting environmental protection and energy conservation and also raising funds for implementation of these programs.

Other regions of Poland have started related programs to address air pollution caused by the low emission sources. This includes: Silesia, Wroclaw, Bytom, and Radom. 


\section{Introduction}

\subsection{Cracow - A Highly Polluted City}

Cracow, the largest city in the south of Poland and the former capital of Poland, is situated on the banks of the Vistula River in the site where Wyżyna Małopolska and Podórze Karpackie meet and form the so called Brama Krakowska.

Cracow, a city of around 741,000 residents and 327 square kilometers, is one of the largest centers of higher education in Poland and is an outstanding cultural and artistic center of particular importance because of the number and kinds of historic buildings located there.

In 1978 the historic center of Cracow was included by UNESCO in the list of the world's cultural heritages. The Ministry Council of the European Union has appointed Cracow with the title of the City of European Culture for the year 2000.

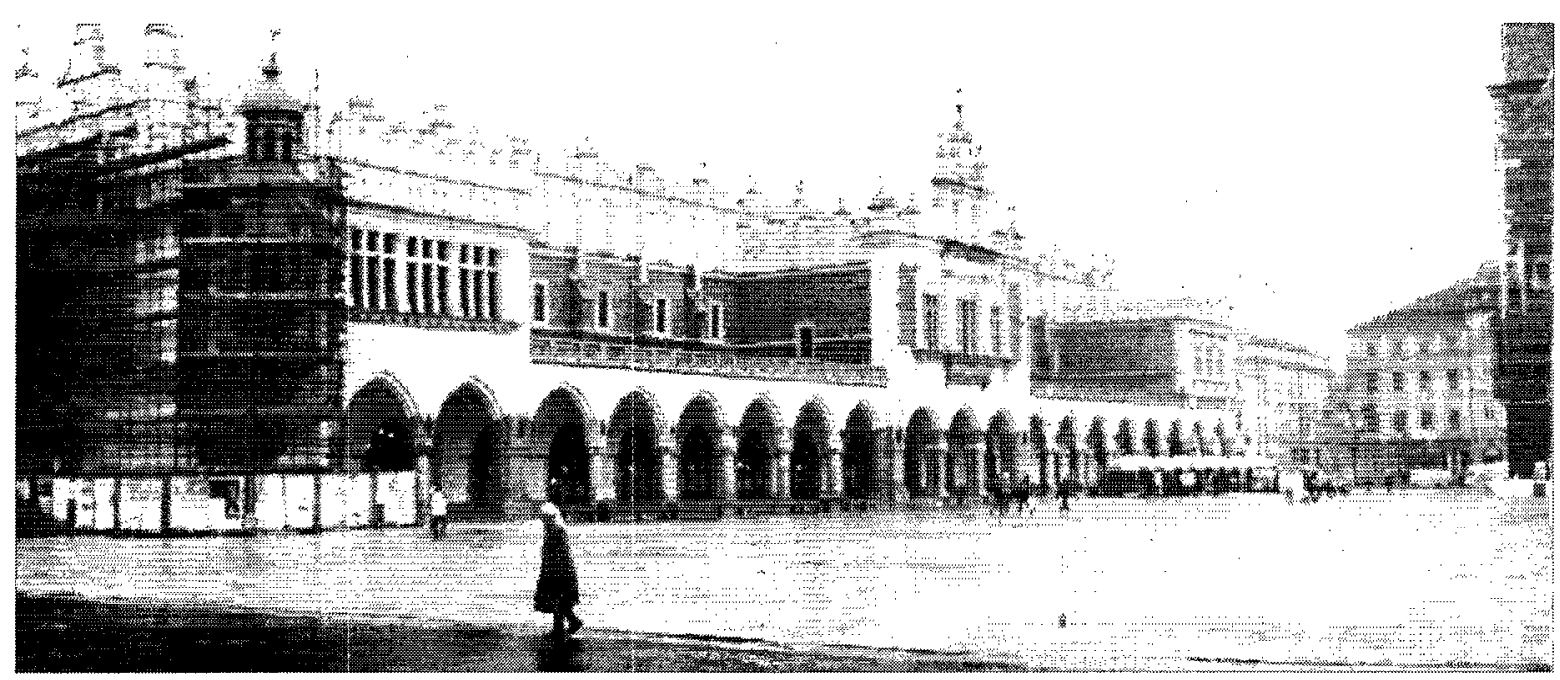

Figure 1-1. The historic market square in Cracow

In 1980 Cracow had severe air pollution problems. The effects of this pollution included increased morbidity among residents and a frightening rate of destruction of priccless cultural heritage. The air pollution was caused by industrial emissions, the influx of pollutants from other regions and by local heat sources "low emission". The 1991 inventory indicated that within the city limits, there were 1,133 solid fuel-fired boiler houses with a combined installed capacity of $965 \mathrm{Mw}$, approximately 100,000 coal-fired home stoves and 17,000 spaces where heat was supplied from small home boilers using solid fuel. The pollution originating from these heating installations is termed "low emissions". It is estimated that in the $1980 \mathrm{~s}$, low emission sources contributed $35-40 \%$ of the total pollution, resulting in the highest concentration of pollutants in the center of Cracow. In 1989, the U.S. Congress adopted the Support for East European Democracies (SEED) Act. The U.S. President George Bush in his speech to the Polish Parliament in July of 1989 said: 
“...economic progress should not come at the expense of our common heritage, our common inheritance -- the environment. In fact, sound ecology and a strong economy can and must coexist. Air and water pollution know no boundaries, and this concern is worldwide. Almost 2 years ago, I visited Krakow, your former royal capital, a city recognized by UNESCO as an international treasure. Today Krakow is under siege by pollution; its priceless monuments are being destroyed. Krakow must be reclaimed, and the United States will help".

The SEED Act directed the U.S. Department of Energy (DOE) to cooperate with the American and Polish experts to undertake an assessment program in Poland to use fossil fuels cleanly in small-scale combustion equipment. The program became specifically directed toward the emissions problems of low emission sources (coal home stoves and solid fuel-fired boiler houses) in Cracow. A total budget of 20 million dollars was allocated. Funding for this program has been provided by the U.S. Agency for International Development (USAID) and the program has been implemented by the DOE in cooperation with various Polish and American institutions and companies: In 1991, U.S. and Polish officials signed a Memorandum of Understanding formally initiating and directing the Cracow Clean Fossil Fuels and Energy Efficiency Program.

\subsection{Program Organization}

Representatives from USAID and the DOE worked with Polish Officials (representatives of the Ministry for Environmental Protection, Department of Environmental Protection of Małopolska Voivodship, and the Cracow City Office) to establish an eight-member Bilateral Steering Committee (BSC) to plan and oversee the Program.

To implement the Program DOE designated:

- Pittsburgh Energy Technology Center (currently part of the National Energy Technology Laboratory - NETL) and Brookhaven National Laboratory (BNL) to address all projects related to the use of solid fuels;

- Pacific Northwest Laboratory for projects connected with energy conservation and extension of the District Heating System;

- The BSC designated Biuro Rozwoju Krakowa (Cracow Development Office or BRK) to manage work implemented in Poland.

The organization of the Cracow Clean Fossil Fuels and Energy Efficiency Program is presented in Figure 1-2, below.

\subsection{Scope of Work}

The objective of the Program was to develop a policy to address the problem of the low emission sources and maximize the improvement in air quality with an optimum use of available funds and minimum increase in the cost of heating. The effort under this program has been focused into 5 main areas of interest as follows: 


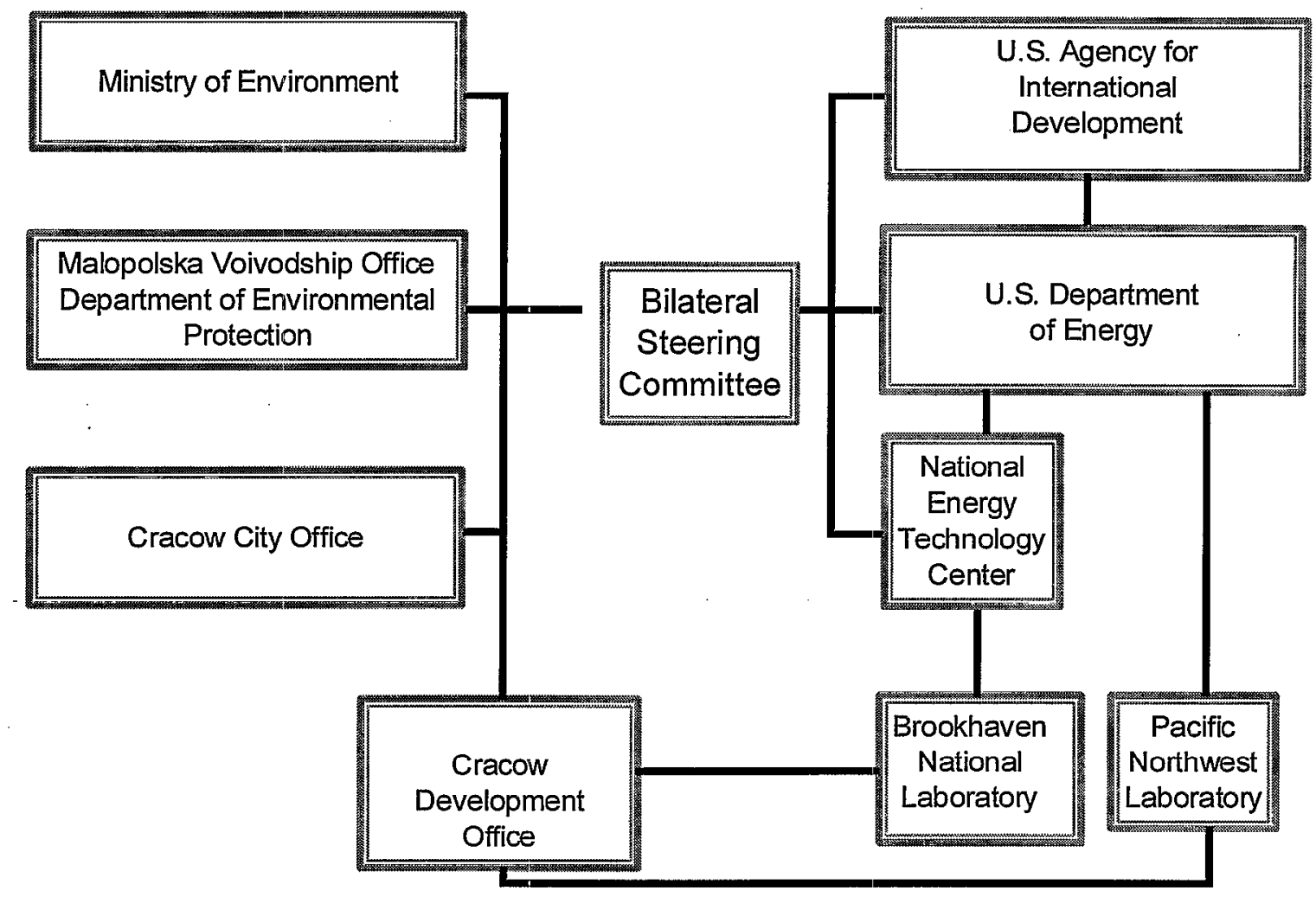

Figure 1-2 Program Organization

\section{Energy Conservation and Extension of the District Heating System}

Energy conservation measures reduce the load and emissions from boiler houses and make more capacity available for expanding the district heating system. Extending the district heating system would eliminate local boiler houses in favor of heat supplied by more efficient, lesspolluting, co-generation plants.

2. Replacement of Coal- and Coke-Fired Boilers with Natural Gas-Fired Boilers.

Replacement of coal- and coke-fired boiler houses is limited to those areas of the city where natural gas is available and where the infrastructure is sufficient to handle the additional load. This is the case in the center city, Old Town, area where low emission sources, boilers and home stoves are concentrated. Gas conversion was studied in Old Town and also in other parts of the city. Some consideration was also given to the installation of very small gas boilers in individual apartments heated with home stoves.

\section{Replacement of Coal-Fired Home Stoves with Electric Heating Appliances}

This subproject involved the installation of electric thermal storage heaters or the retrofit of home stoves with heating coils. Such conversions are feasible in areas of the city where excess 
electrical capacity is available, but require extensive rewiring of buildings and the use of day/night electric rates. The Lobzów region, located northwest of the city center, has been identified as a strong potential site for conversion to electric heating appliances.

\section{Reduction of Emissions from Stoker-Fired Boiler Houses}

Many local boiler houses are relatively new and are far from existing district heating lines. These boiler houses will not be replaced or eliminated, but there are numerous alternatives to increase their efficiency and reduce their emissions. In this area, a multi-optional modernization of one boiler house was considered as an example, including installation of new boilers and new particulate control equipment.

\section{Reduction of Emissions from Coal-Fired Home Heating Stoves}

A process of conversion of coal fired stoves into electric appliances or gas-fired systems is a long-term task. Therefore, this Program also explored if emissions reductions from home stoves are possible through the use of smokeless briquettes or through modified operation of these stoves.

\subsection{Schedule}

The Bilateral Steering Committee defined four phases for the Program:

Phase I was a stage of analyses, tests and design studies. Data on the sources of low emissions was to be collected and possible options for reduction of pollution explored. For each of the options, technical tests of equipment were completed in order to assess potential reductions in emissions, together with an economic analysis evaluating the cost of implementation. The studies developed under Phase $\mathrm{I}$, such as a demonstration project on building energy efficiency measures, analysis of air quality, public opinion surveys, test results analysis and the analysis of options selected were described in the Phase I Report, published by Biuro Rozwoju Krakowa and Brookhaven National Laboratory in 1995.

In Phase II Polish and U.S. companies were informed of the Program, the results of the work done in Phase I, and the opportunities available in Phase III. Public meetings took place in Chicago and Washington in June 1992 and in Cracow in November 1992.

Phase III involved joint implementation, by American and Polish companies, of projects selected through an open solicitation announced by DOE in December, 1992. The solicitation was aimed at identifying U.S. technologies that could be used, in cooperation with Polish organizations, to achieve the program goals. The objective of Phase III was to promote technologies improving air quality, attractive enough economically to enable their further application after the conclusion of the Program. Through the solicitation process, nine projects were selected:

- Honeywell - installation of an automatic control system at the Balicka boiler house and modernization of the heat management in the "Widok" residential area, modernization of heating nodes in the Jana Pawła II and Narutowicza hospitals; 
- Control Techtronics - improvement of the combustion process at a stoker fired boiler house to improve efficiency and reduce emissions (Balicka boiler house);

- LSR - installation of advanced particulate control equipment on coal-fired boilers ("Core Separators");

- Shooshanian - extension of the municipal district heating system and elimination of small boiler houses through connection to the district heating system, training of the Polish professionals in marketing and customer services;

- Tecogen - improvement of the combustion process in a large coal-fired boiler house (the Housing Cooperative's boiler house in Wieliczka);

- Acurex - production of smokeless briquettes for use in home stoves and hand-fired boilers;

- TSC - use of the micronized coal burners in a coal fired boiler houses;

- $\mathrm{EFH}$ - construction of coal cleaning plants to supply improved fuel to stoker fired boiler houses;

- Hart Inc. - support for the investment process, cooperation with heat producers and distributors and elimination of low emission sources through connection to the district heating system.

All American companies selected for the program secured a commitment of financial support from DOE equal to $50 \%$ of the total investment cost. Hart Associates withdrew from the program shortly after selection due to a corporate reorganization.

Shooshanian, Honeywell, Control Techtronics, LSR, Tecogen, have successfully completed their work. For various reasons the other projects were terminated before completion of their scheduled work. All projects are discussed in more detail in Section 3.

Phase IV included the development of a long term strategy for the elimination of boiler houses and home stoves (Phase IV a) and the implementation of projects (Phase IV) covering three groups of activities:

- Elimination of solid fuel fired boiler houses through conversion to gas or through connection to the district heating system;

- Modernization of the entire heating system in the Children's Hospital of the Collegium Medicum of the Jagiellonian University;

- Elimination of home stoves. 
The projects have been implemented with cost sharing provided by the boiler house owners or by "third party investors". The American funds were allocated for use in the preparatory and design works and for the purchase of the basic equipment.

The time schedule of the Program was as follows:

$\begin{array}{ll}\text { Phase I } & 1991-1995 \\ \text { Phase II } & 1992 \\ \text { Phase III } & 1993-1996 \\ \text { Phase IV a } & 1996-1997 \\ \text { Phase IV b } & 1998-2000\end{array}$

\subsection{Budget}

The U.S. Congress allocated $\$ 20,000,000$ for the Program. The BSC divided the funds as follows:

$\begin{array}{lr}\text { Phase I } & \$ 5,500,000 \\ \text { Phase II } & \$ 9,035,000 \\ \text { Phase III } & \$ 3,793,000 \\ \text { Phase IV } & \$ 3,793,000 \\ \text { Other } & \$ 1,672,000 \\ & --.-20,000,000\end{array}$

The other in this list included management, planning, and basic analysis. A very important aspect of the Program was the promotion of local activity and the mobilization of local sources of funding. Investment projects in Phase III and Phase IV were funded mostly by the Polish Program participants: Miejskie Przedsiębiorswo Energetyki Cieplnej S.A (MPEC S.A.)., Elekrocieplownia Cracow S.A. (ECK S.A.), and the boiler house owners. Environmental funds operating in Poland: EcoFund, Voivodship and Municipal Funds for Environmental Protection and Water Management contributed significantly to the implementation of these projects. Financial contribution of the Polish participants is as follows:

$\begin{array}{ll}\text { MPEC S.A. } & \$ 14.375 \text { million } \\ \text { ECK S.A } & \$ 7.988 \text { million } \\ \text { Boiler house owners } & \$ 0.858 \text { million } \\ \text { EcoFund } & \$ 3.487 \text { million } \\ \text { WFOŚ } & \$ 8.907 \text { million } \\ \text { GFOS } & \$ 2.748 \text { million }\end{array}$

The total amount of the financial resources involved in the Program implementation is around $\$ 58.363$ million. 


\section{Phase I Studies}

\subsection{Objective and Scope of Phase I}

The work performed in Phase I embraced the five principal fields described in Section 1.3. In each field the problem was analyzed according to the following scheme: engineering analysis environmental analysis - economic and legal analysis. A public opinion survey was developed along with a wide scope of public relation activities. Several scenarios of elimination or reduction of low emission sources were developed. These scenarios were examined through the use of a spreadsheet model and based on the results of the spreadsheet analysis recommendations were made to municipal authorities.

\subsection{Home Stoves}

At the start of the Program there were about 100,000 coal-fired home stoves in Cracow, half of these were in the center of the town. The total estimated number of home stoves in Poland is around 7 million. These are traditional storage stoves built of brick and covered with ornate ceramic tiles (Figure 2-1). The stoves are generally fired once or twice a day during the heating season. Each firing period lasts about $11 / 2$ hours, during which time the stove mass is heated. After the burning period, the room is heated as the masonry slowly cools. At the laboratory of the Academy of Mining and Metallurgy a stove was installed for testing combustion performance.

The following specific objectives were set for the testing program:

- determine the efficiency of home stoves using various fuels;

- establish pollutant-emission factors for the various fuels;

- to evaluate selected modifications to the combustion process which might increase efficiency or reduce emissions without modifying the stove's construction (i.e. determine an optimum procedure for firing the stove);

- evaluate if small changes in construction might improve the combustion process.

The stove was tested with several different coals, briquettes, and coke using different operating procedures. Tests results showed efficiencies between 45 and $75 \%$, with upper values indicating proper operational procedures and the lower ones representing poor opcrational proccdurcs with major faults. An average efficiency for the population of stoves in the city was $55 \%$, much higher than commonly believed. The strongest adverse effect on the efficiency is prolonged time of combustion, caused by closing the stove doors too late. This reduces efficiency to $47-49 \%$. The impact of other faults in the operating procedure, such as too much air (combustion with top and bottom doors fully open), and leaks after the stove is closed are much less. In tests simulating these faults, the efficiencies obtained fell in the 53-56\% range. Introducing improved operating procedures developed during this program would increase efficiency to about $73-75 \%$. Generally, if the correct operating procedure is used, which is somewhat fuel-specific, then all 
fuels can achieve about the same high level of efficiency. Fuels with the highest volatilcs content require the shortest combustion time. Several modifications of the stove construction were made. These changes did not improve performance.

During stove testing, pollutant emissions were measured for the various fuels tested. Lowvolatile-content fuels - briquettes and coke - have the best environmental performance. With briquettes, performance strongly depends upon operating procedure, and the improved operating procedure sharply reduces overall emissions. With a higher volatiles-content fuel like coal, emissions performance is much less dependent upon the operating procedure. Generally, fuels with the highest volatiles content produce the highest emissions during the initial devolatilization stage of combustion. Changes in operating procedures, which affect the later states of combustion, have little effect on overall emissions. However, with low volatile fuels, the emission rates are more uniform over the entire combustion period; and changes made during the later stages of combustion can affect total emissions during the firing cycle. Average unit emission rates were estimated to total global emissions from all the stoves in Cracow. The results indicated that the stoves are significant contributors to Cracow's pollution. Although consuming much less fuel than the boilers, stoves produce as much or more seasonal particulate emissions. This is exacerbated by the use of cheaper coals.

Emissions from coal stoves can be eliminated by:

- installing electric heating elements in the existing stoves;

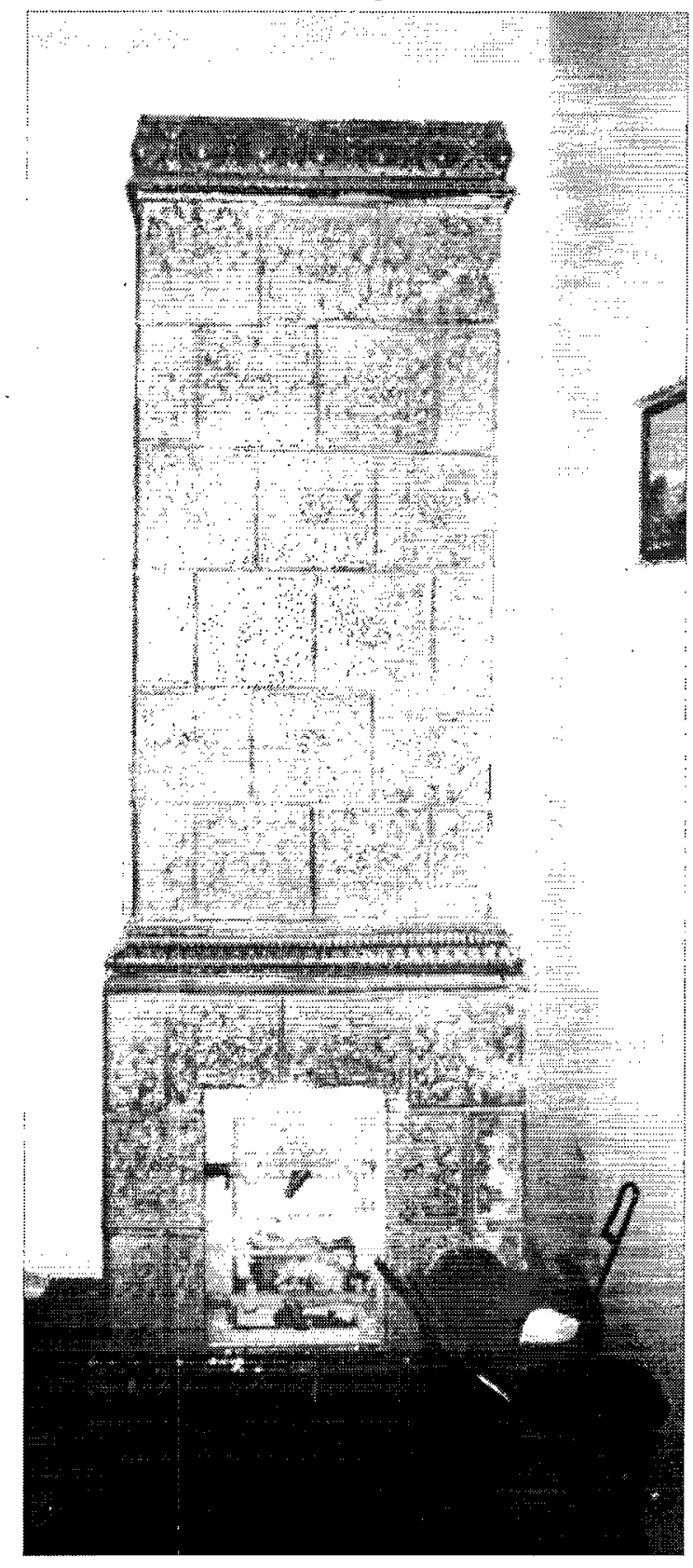

Figure 2-1. Typical coal stove

- conversion to electric heating by replacement with the storage heaters with natural or induced air flow;

- conversion to electric heating by replacement with non-storage electric heaters;

- conversion to gas-fired central heating;

- use of smokeless briquettes. 
Results of the public opinion survey showed that many residents would like to convert their stoves to gas or electric heating. Electric heating was preferred, due to lower investment cost and ease of conversion. The survey results also indicated a willingness on the part of Cracow residents to pay for the convenience of electric heating. The main obstacle to converting to electric heating is the fact that the electric power distribution system is not sufficiently developed to meet home heating needs. The significant increase in use of electricity for heating purposes would require general reconstruction and modernization of the existing electrical distribution system. Particularly the low and medium voltage systems, since they were not specifically designed with sufficient capacity for space heating. The expansion of the electrical distribution system is also limited by the difficulties in finding sites for the construction of new transformer stations.

Elimination of coal-fired homie stoves can also be accomplished by converting to gas-fired heaters. The existing gas distribution system has a sufficient capacity to supply gas for home heating. Utilization of natural gas for space heating on the large scale is restrained by: unfavorable ownership situations, unresolved legal status of buildings, lack of funds for conversion, and technical constraints associated with ensuring the proper removal of flue gases in the old buildings.

Due to technical and economic constraints, it is not possible to convert or eliminate all coal-fired home stoves. Laboratory test results showed that the use of smokeless briquettes could reduce emission of pollutants, especially particulate emissions 12 to 15 times. However, due to the high cost of this fuel, past attempts to introduce briquettes for general use have failed.

\subsection{The Solid Fuel-Fired Boilers}

\subsubsection{Database on Boiler Houses}

At the turn of 1990 and 1991, Biuro Rozwoju Krakowa developed an inventory of the low emission sources in Cracow. One-thousand, three hundred forty-four $(1,344)$ boiler houses with a total design output of $1050.44 \mathrm{MW}$ were recorded, including:

- 1,133 solid fuel- fired boiler houses with a total design output of 963.5 MW; '

- natural gas-fired boiler houses with a total design output of 1.1 MW;

- 1 coke / natural gas-fired boiler house with a total design output of $0.2 \mathrm{MW}$;

- 202 natural gas -fired boiler houses with a total design output of $76.2 \mathrm{MW}$;

- 5 oil-fired boiler houses with a total output of $8.9 \mathrm{MW}$.

The total number of boilers was 2,920 including:

- 2,262 boilers using solid fuel;

- 664 boilers using natural gas;

- 14 boilers using fuel oil. 
The 2,262 solid fuel-fired boilers include:

- 229 boilers with traveling grates;

- 2,033 boilers with fixed grates, of which these are:

- 1,118 coke-fired boilers;

- 685 coke-coal fired boilers (a coal/coke mixture is used as fuel);

- 230 coal-fired boilers.

A significant majority (81\%) of the boilers with traveling grates have air pollution control devices. However, pollution control devices are installed in only $4.6 \%$ of fixed grate boilers.

Fixed grate boilers are manufactured as either cast-iron or steel boilers. Among the cast iron boilers designed to burn coke, ECA and KZ-5 types dominate. Among steel boilers designed to burn coal the most common types are ES-KA, Rumia, ES-ŻET, RSW and RPS. Stoker-fired boilers are designed to use fine coal (5 to $10 \mathrm{~mm})$.

In the town center the inventory showed mainly fixed grate boiler houses with a total rated capacity of $500 \mathrm{~kW}$. Boiler houses with mechanical grates have a capacity in a range of 2-35 MW and supply heat to a group of buildings. Almost all of them have been located far from the town center.

\subsubsection{Fixed Grate Boilers}

Two of the most commonly used types of fixed-grate boilers were chosen for testing in Phase I:

- ECA-IV cast-iron boilers;

- ES-ŻET steel boilers.

The ECA IV boiler is a sectional, cast-iron boiler with a horizontal grate, hand fired from the front or top. Assembling segments allows application of boilers with outputs ranging from 158 to $493 \mathrm{~kW}$. The boiler has an insulated steel-sheet jacket. These are a natural draft boilers and the flow of combustion air into the furnace is regulated by two doors on the boiler's front face. The lower door allows air to feed under the fuel grate. The position of this door is regulated manually or automatically to control firing rate and the boiler's output. The upper door is smaller and is used to introduce air into the region of hot combustion products, reducing emissions of unburned gases. In normal practice this door is kept closed. Flue gases are exhausted into a common breaching ("settling") chamber and a chimney.

The ES-ŻET boiler is a steel, fire-tube boiler. The grate is made of cast iron, is flat and is not cooled. The boiler's jacket is thermally insulated. This boiler comes in sizes ranging from 41 to $530 \mathrm{~kW}$ output. It is a natural draft boiler and the combustion air inlets are similar to those of the ECA-IV boiler. Flue gases pass twice through fire tubes and then go via a smoke box and a metal smoke conduit to a chimney.

The normal operating procedure consists of staring-up a small fire on the grate and then spreading the required quantity of fuel on the grate surface. After this portion of fuel burns, the 
fire is not dumped, but again the furnace is filled with fuel. The combustion rate and the boiler's output is regulated by operating the lower air-shutter in the furnace's front face, thus controlling the entry of primary air. Combustion is evaluated by an operator, guided by observing the color of the flame in the furnace. The only equipment for control and measurement on the boiler are thermometers and pressure gauges on the boiler's inlet and outlet.

The aim of the testing program was to determine the boiler system efficiency and particulate and gaseous emissions as a function of:

- kind of fuel;

- manner of combustion;

- thermal load;

- quantity of air supplied during combustion.

Three load levels and three kinds of fuels: coke, coke/coal mixture, and smokeless briquettes were tested. Because of technical arrangements the boilers could not be tested individually but rather had to be tested as a boiler system. The load on individual boilers was varied by changing the number of operating boilers. Effect of overfire air was evaluated on the cast iron boilers.

The cast iron boilers' efficiencies ranged from $65 \%$ to $73 \%$. The highest efficiency was achieved at medium load, with boilers firing coke. The use of coal-coke mixtures reduces boiler efficiency and increases emission factors. These boilers should be fired with coke only. For the steel boilers the efficiencies ranged from 53 to $71 \%$. The highest efficiency was achieved at the medium load burning briquettes, the lowest in runs with coal fuel. Burning briquettes also gives the lowest emission rates. Briquettes are the most favorable fuel for this type of boiler. For both types of boilers, changes in the operational procedure did not have a big impact on the efficiencies of combustion. For cast-iron boilers, the overfire air should be introduced at the beginning of the firing cycle to minimize $\mathrm{CO}$ and $\mathrm{CH}_{4}$ emissions. An increase in overfire air, provided for combustion, gives higher values of particulate emissions.

Reduction of emissions from the fixed grate boilers is possible through:

- conversion to gas;

- connection to the district heating network;

- conversion to heating oil;

- use of smokeless briquettes.

The existing district heating system has excess capacity, which can be used for heating purposes. Local gas networks must be modernized to allow for expansion through reconstruction and extension of the medium pressure pipelines and construction of several reduction stations. It also will be necessary to reconstruct low pressure pipelines or construct new sections.

The municipal District Heating System does not cover the old Town part of Cracow. The District Heating System does exist in the neighborhood of the city center, however, the existing system can not provide heat to all city regions. An extension of this system is needed, which would include construction of several main pipelines. Connection of local boiler houses to the existing 
municipal district heating system will require the construction of several hundred meters of connecting lines. Justification of the connection of a specific local boiler house to the municipal district heating system, compared to the alternative options of heat supply, is based on the results of an economic analysis.

Conversion of boiler houses to heating oil is also feasible in each town area. Because of higher cost of the fuel, conversion to oil-fired boiler house is planned only in the areas where natural gas and district heating systems are not available.

As in the case of home stoves, smokeless briquettes are not available as a fuel for fixed grate boiler houses. Due to high cost of this fuel, the attempt to introduce briquettes for general use failed.

\subsubsection{Stoker-fired Boiler}

Under the Program two types of stoker-fired boilers were selected for testing:

- WR 10 water boiler;

- PLM 2.5 Steam boiler.

Both boilers are La Mont type and are very similar in design. La Mont type boilers are stokerfired, water tube, forced circulation boilers. Smaller boilers are single-pass and larger ones (with rated capacity of 5 and $10 \mathrm{Gcal} / \mathrm{h}$ ) are two-pass boilers. The main components of the boiler are the heating system, mechanical grate, supporting structure with boiler jacket, exhaust system for flue gases, and a drum in the case of steam boilers. The heating system consists of coils inside the boiler that are welded to the inlet part of the lower collector (water boilers) or to the drum (steam boilers). The inlets to the coils have jets to ensure balanced distribution of water. The heating system is attached to the supporting steel structure standing on the concrete foundation of the boiler. Coal is fed to the boiler from the top by a bucket conveyor. The height of the coal bed on the grate is maintained by a coal gate. A scale-type (single or double) grate is powered by an electric motor. The speed of the grate is controlled by a four-speed or two-speed mechanical gearbox. Under the grate, in the lower part of the structure, there are two steel plate ash pit chutes: at the front for removal of material falling down through the grate, and at the back for removing slag falling off the end of the grate. The inside of the boiler is lined with refractory bricks and the outside with regular bricks. The furnace chamber is additionally protected by thermal insulation. Air to the boiler is not pre-heated. Primary air is fed under the grate by a forced-draft fan. Behind the boiler there is a battery of six cyclones and an induced draft fan. Additionally, the WR-10 boiler has an overfire air fan blowing secondary air to the combustion chamber above the grate. Overfire air fans commonly are used with boilers of this type to promote mixing and complete combustion of volatile fuel components. Primary air is fed through the grate in zones and its distribution among the zones can be adjusted by manual dampers. These dampers match the distribution of air along the grate with demand for air of the burning fuel bed.

During normal operations, the operators have only a very limited scope for regulating the boiler. The heat load on the boiler is regulated by the thickness of the fuel bed maintained by the coal gate. The speed of the mechanical grate is constant, fixed for the kind of fuel fired. The overfire 
air fans normally are not used and the chimney draft normally is not regulated. These boilers are operated with extremely high levels of excess air. This is particularly true at low loads as air dampers often are set for high loads and then not adjusted as load is decreased. All firing controls are manual, and generally flue gas analyzers for determining excess air are not available at the sites.

The aim of testing was to:

- determine the boiler system efficiency as a function of fuel type;

- determine the emissions of pollutants as a function of fuel type;

- determine the optimum operating procedure through adjustment of such parameters as: boiler heat load, the speed of the mechanical grate, quantity of overfire air supplied during combustion, and the amount of secondary air.

Three kinds of fuels: bad quality coal duf (the fucl normally used), good quality coal duf, and washed coal were tested for three loads.

Using the normal operating procedures, testing found efficiencies of 50 to $60 \%$ for the PLM-2 boiler and 60 to $70 \%$ for the WR 10 boiler. The lower efficiency values were obtained during operation with minimum load. The primary reason for such a dramatic decrease in efficiency with decreasing load is the lack of air control, leading to extreme excess air levels at the reduced loads. The low efficiency of the boilers was caused by their poor condition and limited instrumentation and controls. Optimizing the grate speed for a particular fuel and load was found to give an increase in efficiency of $7 \%$. The control of primary and overfire air during the combustion process is time consuming and burdening and above all requires a flue gas analyzer, normally not available to operators. It was estimated that, with the use of improved fuels in combination with optimization procedures, the efficiency of the combustion process can be improved by $15 \%$ and the emission levels can be reduced over $50 \%$. The most favorable fuel for stoker-fired boiler houses is good quality (washed and graded) coal.

Methods for reducing emissions from Stoker-fired boilers are the same as for boilcrs with a fixed grate. Additionally, boiler house modernization can be considered. To improve the operation of one of the tested boiler houses (PLM-2.5 boilers in a very bad technical condition), several modernization options were considered including replacement of the existing boilers with: vibrating grate-spreader stokers, fluidized bed boilers, oil boilers, and installation of air pollution control equipment.

This boiler house provides high-pressure process steam for industrial processes and space heating for companies. The capital costs were high in each option, particularly the option with full supplies of American equipment. The lowest capital costs are incurred in options with oil-fired boilers, but the operational costs for these options are the highest due to the high fuel price. Since customers have resigned from continued steam purchase due to business changes the modernization of this boiler house was not implemented. The scope of modernization justified by economic and engineering analysis should be limited to control of the combustion process. Such a task has been successfully done by Control Techtronics and Honeywell under Phase III and is described in Section 3 of this report. 


\subsection{Energy Conservation Demonstration Project}

The Cracow building stock, typical of most of Poland, includes about 1000 buildings made of prefabricated concrete panels with little thermal insulation. These buildings are usually heated by the municipal district heating system or by local coal- or coke-fired boilers. Energy conservation is a potential method of reducting pollution caused by the building heating systems. To reduce the amount of heat needed in a building, weatherization and insulation measures are necessary, but also installation of controls which can adjust the amount of heat supplied to current weather conditions. To fully encourage energy efficiency, economic incentives are also necessary. The Cracow Demonstration Energy Conservation Project had three major aspects:

- building envelope improvements, to reduce the requirement for heat and improve comfort of residents;

- building-level controls to reduce the amount of heat delivered to the building depending on the weather conditions;

- thermostatic controls of individual rooms and incentives for the residents to use them.

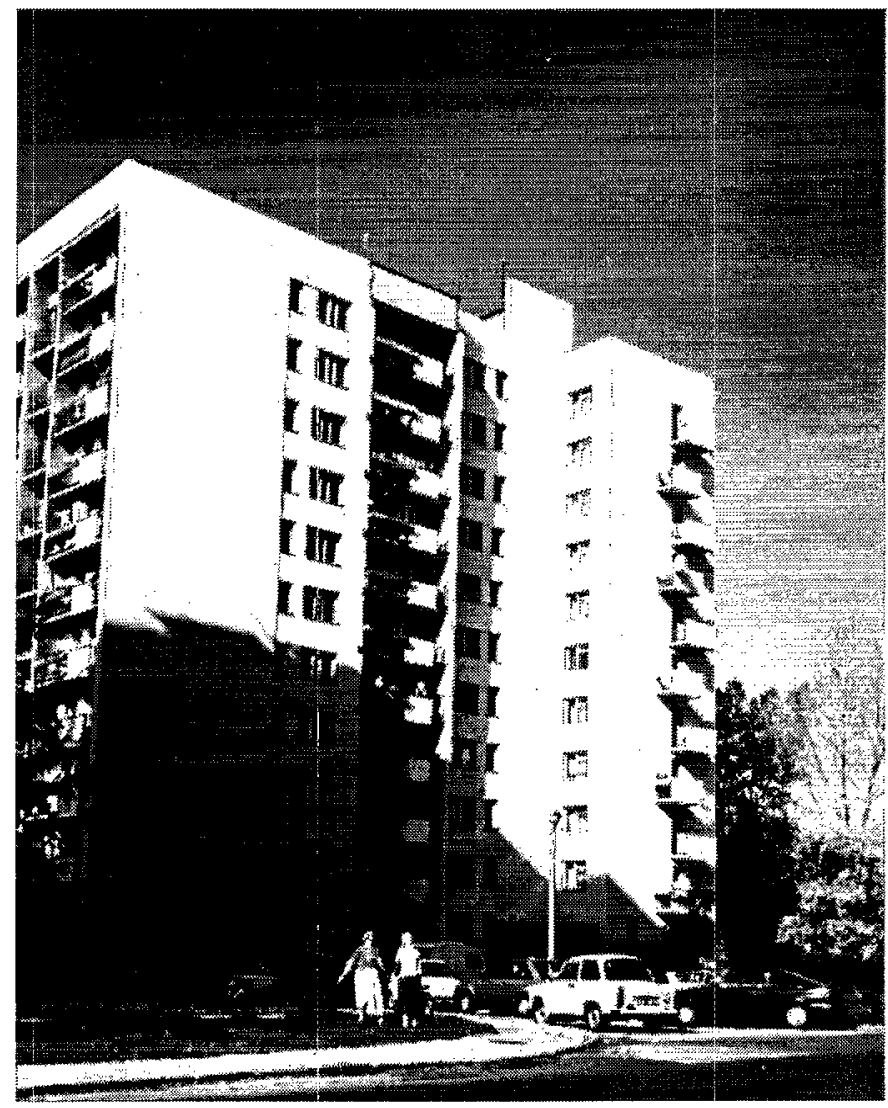

Figure 2-3. Typical Cracow apartment building 
Four adjacent "identical" buildings were selected for the project. A heat meter and data collection system were installed in each building. To encourage energy savings, the residents received financial rebates if their energy use was below a certain pre-calculated target. During two heating seasons different energy saving options were tested. Energy savings were calculated for each set of thermo-renovation measures under evaluation.

- An energy savings of 8 to $14 \%$ was obtained in the building in which a heat exchanger (or hydroelevator) with a temperature-reset control was installed;

- An energy savings of $19 \%$ was obtained when a heat exchanger with temperature-reset controls and thermostatic valves were installed in a building that had been weatherized and had attic insulation;

- An energy savings of $32 \%$ was obtained when a heat exchanger with temperature-reset controls and thermostatic valves were installed in a building that had been weatherized and had attic and external wall insulation.

The analysis showed that, the heat exchanger with temperature-reset controls, thermostatic valves, and attic insulation are the most cost effective measures that provide payback of investment costs. Other measures tested, i.e. external insulation and basement insulation did reduce energy consumption, but were not cost effective. The demonstration project demonstrated the efficiency of low cost measures that increase comfort of the residents and provide an energy savings. Often, there are measures that can be applied by the residents themselves such as:

- caulking windows and door frames and cracks in walls;

- weatherstripping windows and doors;

- installing door sweeps and thresholds on entry and balcony doors;

- installing reflective barriers between radiator and the wall;

- sealing openings in attic;

- insulating the top apartment ceiling or the building roof;

- insulating the basement ceiling.

To fully encourage energy efficiency through the implementation of building conservation measures, these measures must be supported by a system of financial incentives and technical support so that people who use heat:

- can individually control their usage;

- have an economic incentive to reduce their usage.

The results of this demonstration program suggest that conservation strategies may be key to many alternative solutions to reduce low-emission sources through: 
- connecting more customers to district heating networks and eliminating solid fuel-fired boilers, houses, and stoves without requiring the construction of new combined heat and power plants and extension of the gas or electric distribution systems;

- additional incentives to replace solid fuel-fired boiler houses with efficient, environmentally sound heat sources in the form of a heating cost reduction. 


\section{Phase III Projects}

The objectives of the work done in Phase III were to provide assistance in reducing pollution caused by low emission sources and the creation of joint-ventures to promote sustainable activities which would provide benefits beyond the end of the program. As a result of a solicitation conducted by the US Department of Energy, nine American companies were selected for participation in Phase III:

- Control Techtronics International Inc.;

- Honeywell, Inc.;

- Shooshanian Engineering Associates, Inc.;

- LSR Technologies, Inc.;

- Tecogen, Inc.;

- Acurex Environmental Corporation;

- TCS Inc.;

- EFH Coal Company;

- Hart Associates.

Shortly after selection, Hart $\Lambda$ ssociates, which planned a joint-venture with ECK S.A. and MPEC aimed at developing incentives for connecting local boiler houses to the district heating system withdrew from the Program and closed its office in Poland due to corporate reorganization. The remaining companies started the demonstration projects introducing the technologies of clean fuels and energy savings. Each of the American companies found in Poland an appropriate partner for joint project implementation. The projects were completed with different degrees of success, but collectively have helped the American companies start businesses on the Polish market and had their contribution in improvement of air quality in Cracow.

\subsection{Control Techtronics Inc.}

Control Techtronics International, Inc. (CTII) is a controls manufacturing firm based in Harrisburg, Pennsylvania. The company, established in 1984, specializes in the design, development, manufacture, and application of advanced combustion and process control systems.

Under this project CTII introduced to the Polish market their advanced control technology for stoker-fired boilers. CTII worked together with the Municipal District Heating Company (MPEC) in Cracow. Partners in the venture also included two Polish companies, Energoaparatura (ENAP) and Naftokrak-Naftobudowa (NK-NB). ENAP was responsible for control panel fabrication and NK-NB for controls installation. The controls were manufactured in the U.S by CTII. Pennsylvania State University and Cracow Polytechnic University worked together to translate U.S. technical manuals and provide operator training under this project. Cracow Polytechnic also provided performance testing of the boilers. The project was completed at the Balicka boiler house. The Balicka boiler house was built in the 1968-72 time frame and has three WR 10 water boilers, two WLM 2.5 water boilers and two PLM-2.5 steam boilers. The boiler house produces hot water for residential buildings located in its neighborhood and process steam for local plants. Two complete automatic control systems were installed - one managing the operation of the three WR 10 boilers and the second managing two PLM 2.5 steam boilers. Modernization of the two WLM2.5 water boilers has been abandoned due to recent reductions in heat demand and no prospects for 
further use of the boilers. The work was completed by CTII, with the use of some equipment provided by Honeywell. The measured parameters were: water flow and outlet temperature for water boilers or steam flow and pressure for steam boilers, combustion chamber pressure and flue gas oxygen content as a measure of excess air. For each of the boilers the automatic system controlled three parameters: stoker grate speed to adjust firing rate, forced draft fan speed, and induced draft fan speed. After installation, one of the WR 10 and one of the PLM 2.5 boilers were tested for efficiency and emissions. Results showed that the use of controls reduced particulate emissions by 85 percent at mean annual load and resulted in an energy savings of 25 percent. The graphs presented in Figure 3-1 illustrate these dramatic results.

PLM 2.5 Particulate Emissions

$$
-\Delta-\text { Before }-\square-\text { After }
$$

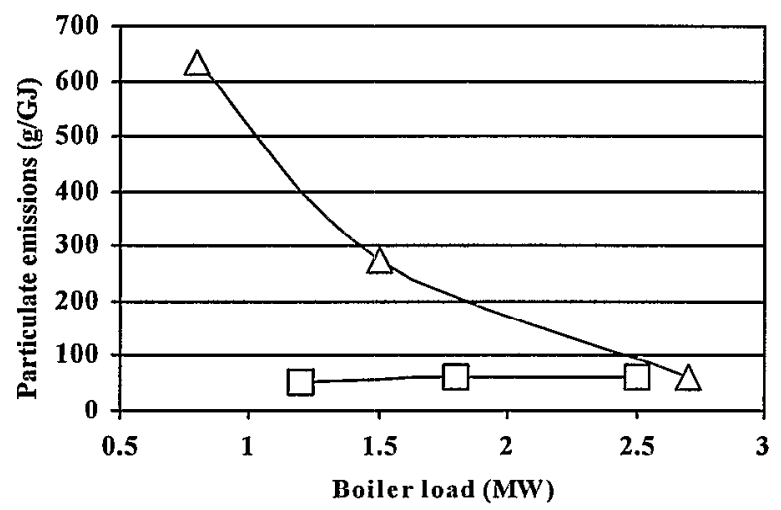

PLM 2.5 Efficiency

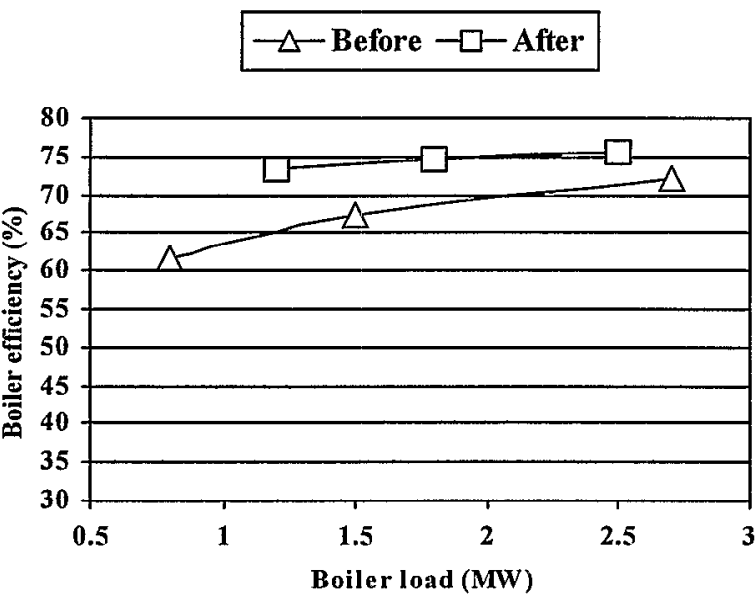

WR-10 Particulate Emissions
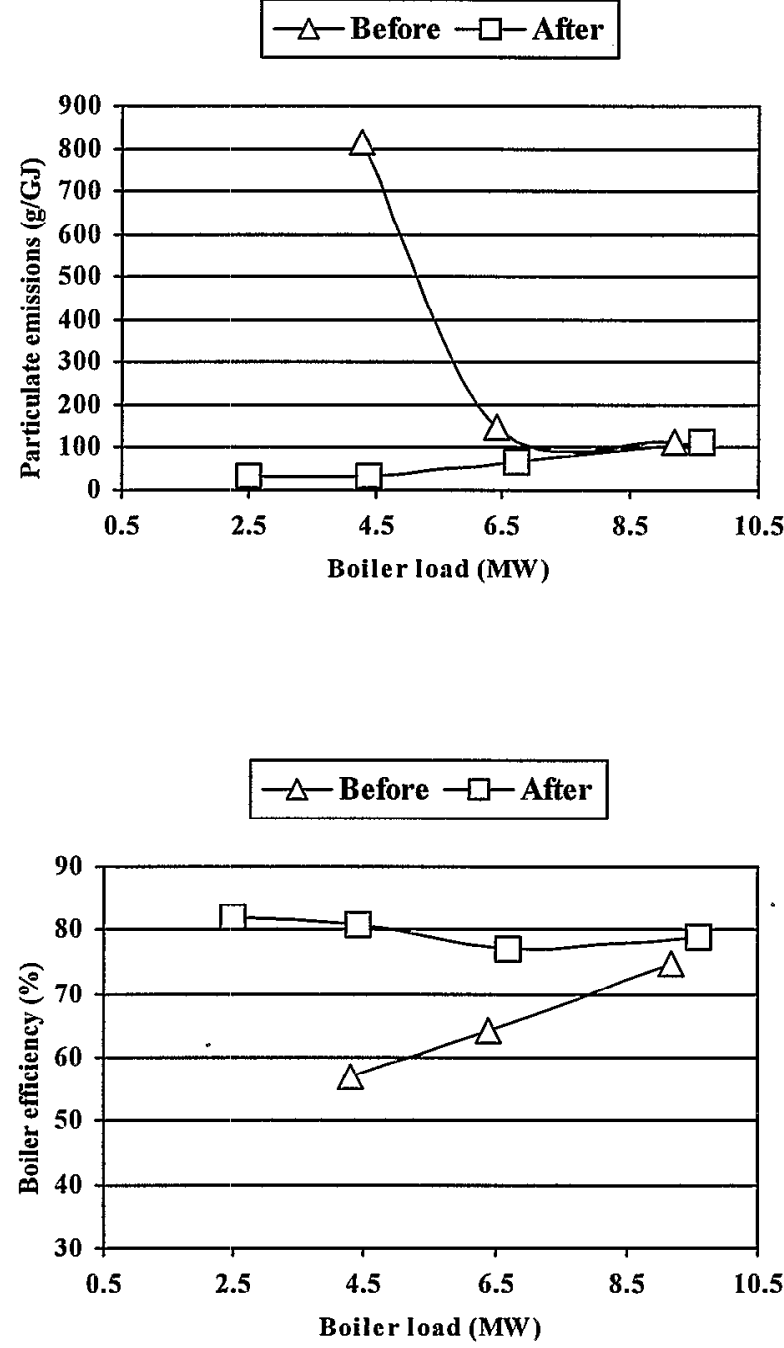

Figure 3-1. Results of installation of CTII controls at Balicka 
The reduction of emissions from the Balicka boiler house obtained due to completion of two projects (by CTII and Honewell) was:
- particulates
-101 tons/year;
- sulfur dioxide
- 36 tons/year;
- nitrogen oxides
- 9 tons/year;
- carbon monoxide
- 9 tons/year.

Stoker fired-boilers are commonly used throughout Central and Eastern Europe. Large and mid-sized coal-fired boiler houses utilize stoker-fired boilers to produce steam and hot water that is used by industry and district heating systems. Advantages of stoker-fired boilers include fuel flexibility and relatively low requirements for fuel preparation.

One way to reduce low emissions under the program was the conversion of the stoker-fired boilers to environmentally clean fuels, or their elimination through connection to the district heating system. These options require large capital investments and lead to increased operating costs. There are some points in favor of keeping the existing stoker- fired boiler houses: relatively low investment cost for plant modernization, possibility to burn cheap fuel, and low operating cost. Efficiency of these boiler houses can be improved by introducing automatic controls and optimizing operating procedures. The pollution emissions can be reduced to the levels imposed by the standards. Dramatic improvements can be made to the efficiency and emission levels of these existing boiler houses for significantly less money than the cost of conversion. This has essentially been the motivation behind the Control Techtronics project.

Another important aspect of the CTII project was operator training. Even with advanced controls and proper fucl sclection, efficiency and emissions benefits can be improved through proper operating procedures. The basis for the operator training program was educational material developed by the Penn State Facilities Engineering Institute in the U.S. The American engineers worked closely with faculty members at Cracow Polytechnic University to translate this educational material and adapt it to Polish conditions.

\subsection{Honeywell, Inc.}

Honeywell is a major worldwide controls manufacturer, established in Minneapolis, Minnesota in 1885. Its first European subsidiary began operation in 1934. Honeywell now operates in 95 countries, including Poland.

The Honeywell project involved a complex modernization of the heating systems of the Balicka boiler house and the Bieńczyce Housing Cooperative and the installation of controls in the boiler houses of the Jana Pawła II and Narutowicza Hospitals. Honeywell worked jointly with Cracow Heat and Power Plant (ECK S.A.) on replacing, by network connection, four major boiler houses (supplied heat exchanger substations and control system). The project has demonstrated that significant cnergy savings can be obtained both at the stage of heat production due to installation of combustion controls and at the customer-side heat supply system, due to control of the heat amount supplied to the building (temperature reset control in heating nodes) and to the apartments (thermostatic valves).

Under the project Honeywell cooperated with: 
- MPEC - Balicka boiler house modernization;

- ECKSA - modernization and construction of heating nodes;

- Widok and Bieńczyce Housing Cooperatives - modernization of central heating installation in residential buildings.

The essential part of Honeywell's project involved the complex modernization of the heating system at the Widok housing estate. This is a local system supplied from the MPEC Balicka boiler house, and not connected with the municipal district system. This is the same boiler house, in which CTII had installed combustion controls and Honeywell and CTII cooperated in the area of control interface. The breakdown of the load served by the Balicka boilerhouse is as follows:

\begin{tabular}{|l|c|}
\hline Consumer & \% of consumption \\
\hline Widok Housing Cooperative & 46.0 \\
\hline Industry & 39.0 \\
\hline Widok-Zarzecze Estate - single family houses & 10.0 \\
\hline Detached single family houses & 5.0 \\
\hline
\end{tabular}

The Widok Housing Cooperative includes 22 buildings with 2,750 apartments, and houses 7,500 residents. Prior to the program, each building had hydroelevator nodes in the basement which mix return water with hot district heat system water. The apartment had no individual room temperature control.

The scope of work for this effort included:

- Installation of automatic controls and optimization of the boilers combustion process. This work was done by CTII in cooperation with Honeywell and has been described in Section 3.1 above.

- Control and monitoring of the pump system. Controllers were installed to enable control of pump speed. At the outlet of the heat exchanger stations heat meters and control valves were installed along with a system of monitoring distribution networks and connection nodes. Also a central dispatch room with supervision, monitoring and control stations was established.

- Modernization of connection nodes. Under the project the following modernization work was performed:

- 46 hydroelevator nodes at the Widok residential buildings were replaced with compact heat exchanger nodes and equipped with Honeywell EXCEL 20 controllers;

- 4 compact hydroelevator nodes in the shopping pavilion were replaced with compact heat exchanger nodes and equipped with EXCEL 20 controllers;

- 7 nodes in public utility buildings, including 5 hydroelevator nodes and 2 multifunctional nodes (central heating + hot water + ventilation); onefunction nodes were equipped in EXCEL 20 and multifunctional nodes were equipped with EXCEL 100; 
- 7 heating nodes at the Academy of Agriculture, including 4 single-function nodes were equipped with EXCEL 20 controllers and two multifunctional nodes (central heating + ventilation) were equipped with EXCEL 100.

- Modernization of the Widok-Zarzecze group heat exchanger This group heat exchanger supplies heat for 117 customers, mainly one family buildings. The automatic control system was completely modernized. The EXCEL controller installed enables temperature reset control, circulating pump control, and control of stand-by pumps.

The main heating nodes parameters are measured continuously and the status of circulating and stand-by pumps are monitored. One of the pumps is equipped with a variable speed drive, allowing control of the capacity. The control system enables the sites to work without operating staff. Eighty heat meters were installed in the buildings.

- Modernization of the internal heating installation In cooperation with the Widok Housing Cooperative the central heating system was modernized in 22 residential buildings and 4 pavilions belonging to the Cooperative. The modernization work included:

- washing and cleaning of equipment to remove internal deposits and impurities;

- sealing of the installation by replacing the central deaeration system with individual automatic deaerators in each of the vertical pipes and installation of membrane vessel;

- installation of control valves for the vertical pipes;

- hydraulic control of installation.

Besides the central heating installation for the Balicka boiler house, the Honeywell project included Bieńczyce Housing Cooperative (47 buildings with 16,000 inhabitants), Jana Pawła II and Narutowicza hospitals and several other sites. Main accomplishments of this project include:

- Complete reconstruction of the heat exchangers and the heat distribution system in Jana Pawła II and Narutowicza hospitals. Central control systems were installed at both of these sites;

- Upgrading of the internal building heating system in the buildings of the Bieńczyce Housing Estate (8 multistory residential buildings). This work included removing, cleaning and reinstalling radiators, installation of thermostatic radiator valves, testing and restarting of the system and training of the residents;

- Removal of 4 large local boiler houses and replacement with 4 heat exchanger installations (11.8 MW capacity). These boilers were located on the main network and 
Honeywell cooperated with ECKSA in this case. ECKSA is the co-generation plant that supplies the City's main district heating network;

- Cooperation with ECKSA on the installation of 85 additional heat exchanger substations allowing the elimination of local coal-fired boiler houses (41.0 MW capacity). These sites were again connected to the main network. Honeywell's role at these sites was limited to delivery of instrumentation and control and related project services such as project management, engineering, installation, and startup.

At the Widok Housing Estate two methods of analysis were used to estimate the impact of replacing hydroelevators with controlled heat exchangers, installing of thermostatic radiator valves in apartments and the general overhaul of the internal heating system. In the first method, the energy use in modernized buildings was compared to that in very similar buildings that had not been modernized. In the second method, cncrgy use in specific buildings was compared before and after modernization. Modernized buildings used 7 to $17 \%$ less energy - although, in some cases savings over $25 \%$ were determined. Considering all of the data analyzed, Honeywell estimates an average energy savings in modernized buildings of $15 \%$. Honeywell further estimates that energy use will be reduced an additional $5 \%$ in the future as residents become more experienced with thermostatic radiator valves.

The improvements made to the district heating network supplied by Balicka resulted in significant benefits in addition to those achieved by CTII's project to modernize the boiler's controls. Overall, the fuel reduction at the Balicka boiler house is estimated to be about 33 percent, or 5,500 tons of coal per year. Also, the Honeywell project resulted in a reduction in electrical consumption at Balicka of 29 percent. The work with ECK S.A. which eliminated boiler houses by connecting them to the district heating system resulted in an additional reduction of:

- particulates - 690 tons/year

- sulfur dioxide - 590 tons/year

- nitrogen oxide- 129 tons/year

- carbon monoxide- 950 tons/year

Honeywell has used this project to strengthen its position in the Polish and Eastern European markets. Honeywell's presence in Poland has evolved from an entrepreneurial unit in an emerging market to an established ISO-certified affiliate. During the course of this project Honeywell's affiliate in Poland has developed an understanding of the political, legal, financial and economic factors that shape the conservation market in Poland. A market survey developed by Honeywell confirmed a big demand for equipment and services connected with energy efficiency both in Poland and in other East European countries. Honeywell expects to capture a significant share of the growing thermostatic radiator valve market in Poland as well as Eastern Europe. To extend its capabilities, Honeywell created Honeywell Poland ESCO. The ESCO provides financing for projects connected with energy efficiency, assists customers in assessing their requirements, offers comprehensive technical solutions, and manages cash flows and entire projects. In cooperation with the Cracow firm Dempan, Honeywell established a thermostatic radiator valve assembly facility in Poland. 


\subsection{Shooshanian}

Shooshanian Engineering Associates was founded in 1961 and is based in Boston, Massachusetts. Shooshanian is a mechanical and electrical engineering firm specializing in study, design, and construction services.

Projects completed by Shooshanian in cooperation with its Polish partners focused on extension and improvements of the district heating system, thus permitting elimination of the local coal- and coke-fired boiler houses through connections to the district heating network.

Extension of the district heating system was a joint project of:

- Shooshanian Engineering Associates, Inc.;

- MPEC; and

- Polinvest Spólka z o.o., an economic and legal consulting firm.

The scope of the project comprised five major tasks:

- identification and evaluation of potential district heating clients, development of client offerings (including engineering and economic analyses), and negotiation of contracts;

- engineering design of new customer connections;

- construction activities including modernization of the hot water distribution system and connection of customers;

- training for MPEC personnel in the field of:

- marketing, customers services, and strategic planning practices, including assistance in establishing a Marketing Department and Customer Service Office;

- energy conservation studies;

- project management and funding techniques; and

- financial planing and analyses of legal issues, joint-ventures formulation.

As a result of the project, several sites located within Cracow, supplied with heat from the local solid - fuel fired boiler houses were connected to the municipal district heating system. The project was divided into two stages. Under the first stage of project implementation, sites with a total capacity of $7.239 \mathrm{MW}$ were connected to the district heating system. Estimated fuel use by the boiler houses prior to connection was 3,220 tons/year. Under the second stage of project implementation sites with a total capacity of $21.231 \mathrm{MW}$ were connected to the district heating system. Estimated amount of fuel used by these boiler houses was 9,973 tons/year.

In total, 33 sites or building complexes were connected to the district heating system, thus eliminating solid fuel boiler houses with a total capacity of 28.4 MW. Reduction of coke and coal consumption in Cracow due to these connections was estimated at around 13,200 tons/year. It resulted in the following reduction in emissions:
- particulates
-265.6 tons/year;
- sulfur dioxide
- 258.3 tons/year;
- nitrogren oxides
- 54.8 tons/year;
- carbon monoxide
- 388.8 tons/year. 
An important aspect of this project was the development and implementation of a marketing strategy MPEC and Shooshanian designed to help attract new customers.

As a result of changes that took place at the turn of 1980's and 1990's, MPEC has been forced to aggressively compete on the energy market. The issues of marketing, public relations, negotiation, research and customer service all play important roles in expanding the district heating network. Shooshanian developed a Marketing and Customer Service Training Manual for MPEC. In addition, marketing and customer service training was provided and a Customer Service Office was established. The training of MPEC personnel in strategic planning practices and energy conservation studies was also conducted.

During program implementation, discussions were held among three companies: Shooshanian, MPEC and Polinvest on the issue of the future cooperation. Several scenarios of future cooperation have been identified, however, the project did not result in the formation of a formal joint venture. The experience gained during this project continues to be used in the work of the MPEC Marketing Department and Customer Service Office.

\subsection{LSR Technologies}

LSR Technologies, Inc. Of Acton, Massachusetts is a small company specializing in the development of advanced technology for physical and chennical separations. Beginning in 1989 and with support of the U.S. Department of Energy and the U.S. Environmental Protection Agency, LSR developed a new concept for mechanical dust collection - the Core Separator. The LSR work in Poland has involved the retrofit of Core Separators to the existing, coal-fired boilers.

The project involved cooperation among the following companies:

- LSR Technologies, Inc.;

- Eco Instal, a firm from Poznan, that manufactures environmental protection equipment;

- Foundation for Energy Efficiency (FEWE) from Katowice.

FEWE is an independent and non-profit organization formed at the end of 1990 by- Pacific Northwest National Laboratory (USA) with support from U.S. AID. FEWE is involved in projects throughout Poland with three regional centers in Warsaw, Cracow, and Katowice. The general scope of the activities of FEWE include:

- Studies and analyses to support energy efficiency;

- Support for the development of the private sector including joint-ventures with foreign companies designed to transfer into Poland new energy efficiency technologies, knowhow and expertise;

- Training and education of the Polish professionals and implementation of demonstration projects within the energy efficiency field;

- Public education.

As a part of the cooperation with LSR, FEWE has provided assistance and support in marketing. 
At the start of this project, Eco Instal was primarily a manufacturer of pollution control equipment with a total of 30 employees. Under this project LSR transferred to Eco Instal the technology for producing and installing the core separators. As the program progressed, Eco Instal assumed full responsibility for marketing, application engineering, detailed site design, installation, start-up, and performance testing of the core separators.

In Poland mechanical particulate collectors have traditionally been used in place of more efficient control devices in industrial applications due to lower initial and operating costs. The core separator is more efficient than conventional mechanical collectors. Particulate emissions from the boiler houses using core separators are typically 3-6 times lower than those from even the best cyclone collectors. The performance of core separators approaches that of fabric filters and electrostatic precipitators, but at much lower cost.

A simplified schematic of the core separator is shown in Figure 3-2. A core separator includes a cylindrical unit with an inlet for the stream to be treated and two outlets --one for the cleaned gas stream and the other containing a highly concentrated recirculation stream. The dust-laden recirculation stream is fed to the cyclone and then returns again by means of the fan. The processes of separation and collection are accomplished separately in different components. The core separator cleans the inlet stream and detains dust particles in the system. Since its efficiency is quite high, the dust particles cannot leave the system. They recirculate again and again until collected in the cyclone. Up until now, cyclone dust collectors have proven ineffective in removing dust particles with diameters below 10 microns. In comparison, the core separator is able to remove a high percentage of particles even at 2-3 microns. The dust collectors commonly used in Poland on coal-fired boilers typically have an efficiency for particulate capture of 75 to $80 \%$. Applied to the same boilers, the core separator achieves 94 to $98 \%$ capture.

The core separator system can actually be arranged in a variety of configurations, depending on process conditions, required performance, inlet dust concentration, abrasiveness of solids, etc. A typical arrangement is shown in Figure 3-3.

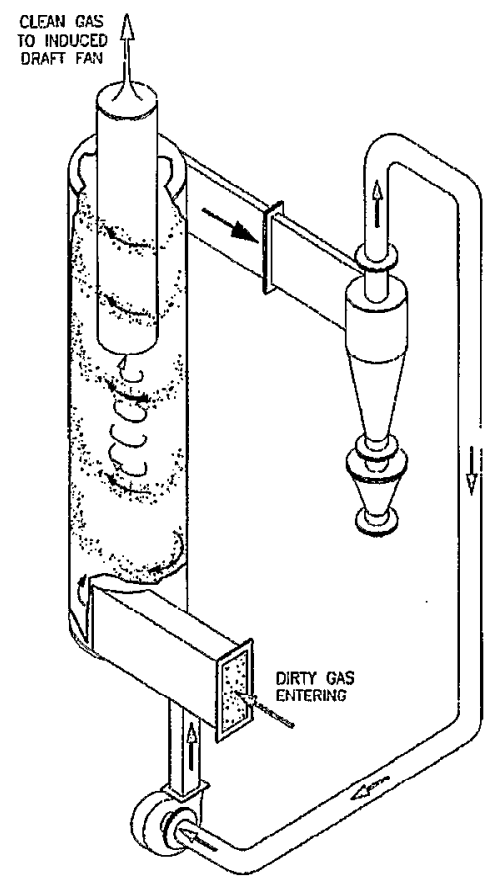

Figure 3-2. Simple illustration of the LSR Core Separator System

The scope of the project included the installation of core separator particulate removal systems at two sites in Cracow:

- KZA Armatura;

- MPK at Makuszyńskiego; 
Core separators were installed at Armatura on the WR-5 stoker-fired boiler and at the service facility of the municipal transport company (MPK) at Makuszyńskiego street on three WCO80 stoker-fired boilers. At each of these sites, testing was done to document actual performance. The boiler at Armatura has a nominal capacity of $6 \mathrm{MW}$ and measured

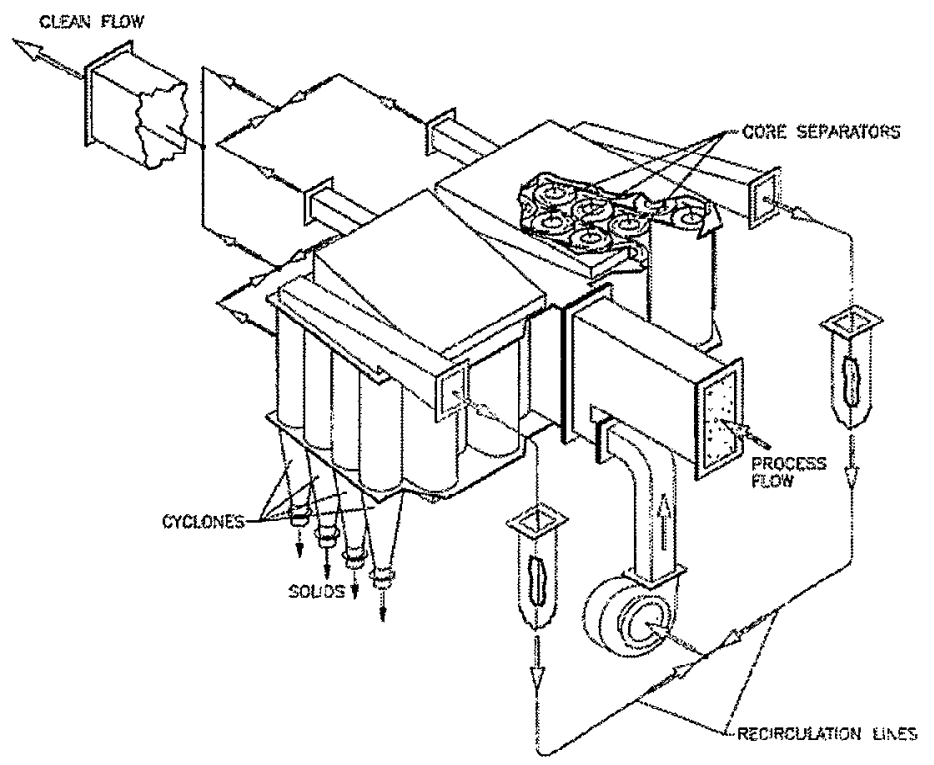

Figure 3-3. Typical core separator arrangement

particulate removall efficiency was $95.4 \%$. At MPK the total boiler capacity is $1.5 \mathrm{MW}$. Two of the three boilers were tested at MPK and measured particulate removal efficiency was $91.4 \%$ and $96.0 \%$.

Beyond the formal scope of this program, Ecolnstal has completed 36 additional core separators installations.

Table 3-1 provides a list of completed projects. Total coal consumption at these sites is estimated at 557,000 metric tons per year. The growth rate of the core separator business of EcoInstal has been very impressive. Figure 3-4 shows the trend in core separator total installed capacity since the project started.

The emissions reduction for two sites in Cracow, formally included in the program were estimated based on the tests results and average operating parameters for each boiler type. Due to installation of the core separators, particulate emission were reduced by 22.8 tons/year.

EcoInstal is continuing to market and install core separators in Poland. As a result of the Core Separators installations employment at EcoInstal has increased from 30 to 100 employees. In 1997, EcoInstal received a national environmental award, largely due to their sales of core separators. 


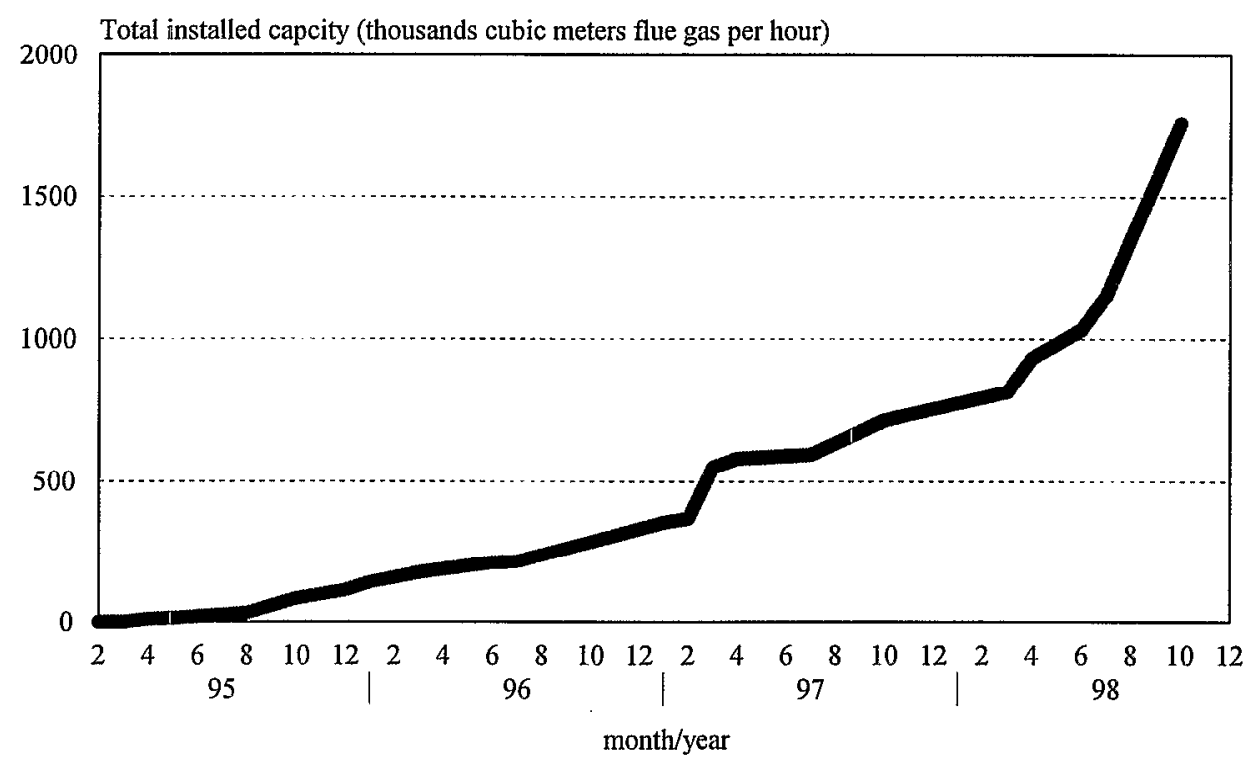

Figure 3-4. Trend in installed capacity of Core Separators in Poland 1995-1998

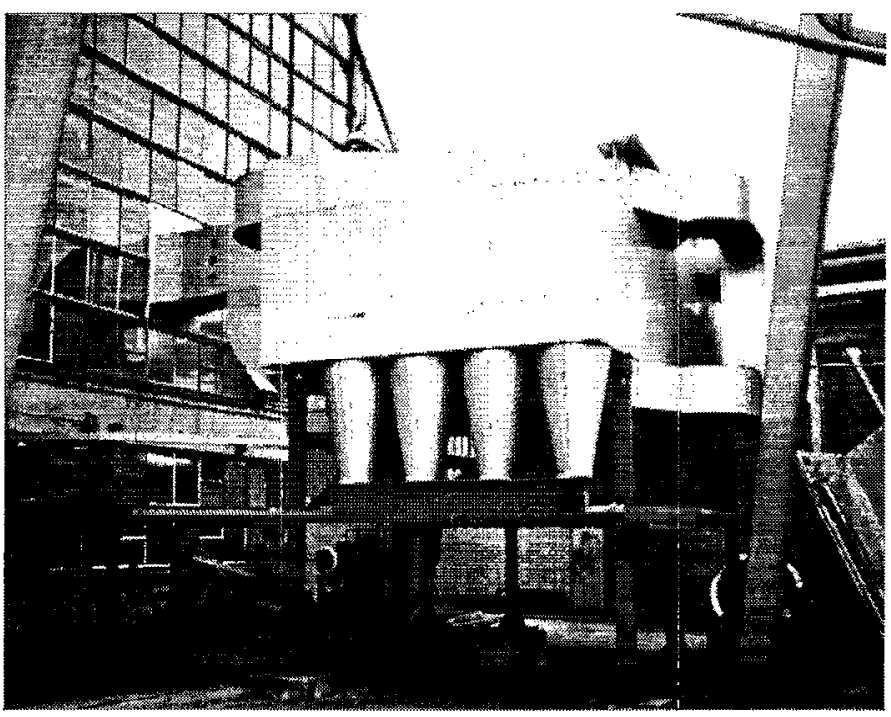

Figure 3-5 Photo of Core Separator Installation in Poland 
Table 3-1. List Of Sites In Poland Where The LSR Core Separator Has Been Installed.

\begin{tabular}{|c|c|c|c|}
\hline Lp. & Investor & Installation & Flue gas flow \\
\hline 1. & Kombinat RSP Czempiń & $3 \mathrm{WCO} 80$ boilers & $3 \times 6.000 \mathrm{~m}^{3} / \mathrm{h}$ \\
\hline 2. & $\begin{array}{l}\text { „BUDOSTAL-6" Dąbrowa Górnicza } \\
\text { ul. Myśliwska } 1\end{array}$ & $\begin{array}{l}\text { Bituminous paving plant } \\
\text { Dust removal }\end{array}$ & \\
\hline 3. & MZC Dzierżoniów & 3 WR 5 boilers & $108.000 \mathrm{~m}^{3} / \mathrm{h}$ \\
\hline 4. & $\begin{array}{l}\text { Odlewnia metali „RADIANA” Golina } \\
\text { ul. Leśna } 6\end{array}$ & Silver production line & $18.000 \mathrm{~m}^{3} / \mathrm{h}$ \\
\hline 5. & $\begin{array}{l}\text { „IZOLACJA MATIZOL" } \\
\text { Gorlice, ul. Biecka } 11\end{array}$ & $\begin{array}{l}\text { Tar board production } \\
\text { line }\end{array}$ & $20.000 \mathrm{~m}^{3} / \mathrm{h}$ \\
\hline 6. & $\begin{array}{l}\text { „EKOBUD" Grudziądz } \\
\text { Grudziądz, ul. Nad Torem } 11 \\
\end{array}$ & SR 15 boiler & \\
\hline \multirow[t]{2}{*}{7.} & Spółka Energetyczna „Jastrzębie” & & \\
\hline & $\begin{array}{l}\text { ul. Armii Krajowej } 44 \\
\text { Ciepłownia „Moszczenica” } \\
\text { Cieplownia „Pniówek” }\end{array}$ & \begin{tabular}{|l} 
PWRp 20 boiler \\
WR 25 boiler
\end{tabular} & $\frac{120.000 \mathrm{~m}^{3} / \mathrm{h}}{110.000 \mathrm{~m}^{3} / \mathrm{h}}$ \\
\hline 8. & $\begin{array}{l}\text { PEC Jastrzębie } \\
\text { Kotłownia w Knurowie }\end{array}$ & WR 10 boiler & $50.400 \mathrm{~m}^{3} / \mathrm{h}$ \\
\hline 9. & $\begin{array}{l}\text { PEC Katowice } \\
\text { ul. Grażyńskiego }\end{array}$ & WR 25 boiler & $120.000 \mathrm{~m}^{3} / \mathrm{h}$ \\
\hline 10. & $\begin{array}{l}\text { PDM Kościan } \\
\text { ul. Bączkowskiego } 30 \\
\text { Oddział Bonikowo }\end{array}$ & Bituminous paving plant & $21.600 \mathrm{~m}^{3} / \mathrm{h}$ \\
\hline 11. & $\begin{array}{l}\text { "BUDOSTAL-5" } \\
\text { Zakład Drogowy Cracow } \\
\text { ul. Blokowa } 5\end{array}$ & Bituminous paving plant & $21.600 \mathrm{~m}^{3} / \mathrm{h}$ \\
\hline 12. & $\begin{array}{l}\text {,KRAKODLEW" S.A. } \\
\text { Cracow ul. Ujastek } 1\end{array}$ & Rotary sand drier & $10.000 \mathrm{~m}^{3} / \mathrm{h}$ \\
\hline 13. & $\begin{array}{l}\text { Cracowskie Zakkady Armatury p.p. } \\
\text { ul. Zakopiańska } 12\end{array}$ & WR 5 boiler & $22.600 \mathrm{~m}^{3} / \mathrm{h}$ \\
\hline 14. & $\begin{array}{l}\text { MPK Sp. z o.o. } \\
\text { Cracow ul. Brożka } 3\end{array}$ & 3 WCO 80 boilers & $3 \times 6.000 \mathrm{~m}^{3} / \mathrm{h}$ \\
\hline 15. & $\begin{array}{l}\text { PRD Kutno } \\
\text { ul. Kardynała Wyszyńskiego }\end{array}$ & Bituminous paving plant & $45.000 \mathrm{~m}^{3} / \mathrm{h}$ \\
\hline 16. & Huta Miedzi „Legnica” & Shaft boiler & $16.200 \mathrm{~m}^{3} / \mathrm{h}$ \\
\hline 17. & $\begin{array}{l}\text { „DEWOO Motor Polska” } \\
\text { Lublin, ul. Małglewska } 7\end{array}$ & $\begin{array}{l}\text { Particulate removal and } \\
\text { desulfurization of } 4 \\
\text { EKM } 50 \text { boilers }\end{array}$ & $220.000 \mathrm{~m}^{3} / \mathrm{h}$ \\
\hline 18. & $\begin{array}{l}\text { SM „ZORZA" } \\
\text { Myślenice, ul. 100-lecia 15a }\end{array}$ & $4 \mathrm{KRm} 1,7$ boilers & $14.400 \mathrm{~m}^{3} / \mathrm{h}$ \\
\hline 19. & $\begin{array}{l}\text { PEC Oborniki Wlkp. } \\
\text { ul. Wybudowanie } 56\end{array}$ & WR 5 boiler & $24.000 \mathrm{~m}^{3} / \mathrm{h}$ \\
\hline 20. & $\begin{array}{l}\text { ZOS „ARGENTECH” } \\
\text { S. Krzysztofiak }\end{array}$ & Melting furnace & $1.000 \mathrm{~m}^{3} / \mathrm{h}$ \\
\hline
\end{tabular}




\begin{tabular}{|c|c|c|c|}
\hline & Opalenica Troszczyn 26b & & \\
\hline 21. & $\begin{array}{l}\text { Instytut Materiałów Mineralnych } \\
\text { Opple }\end{array}$ & $\begin{array}{l}\text { Filling of calciferous } \\
\text { powder }\end{array}$ & $2.000 \mathrm{~m}^{3} / \mathrm{h}$ \\
\hline 22. & $\begin{array}{l}\text { WZS „SKLEJKA-ECO” } \\
\text { Ostrów Wlkp. ul. Reymonta } 35\end{array}$ & WLM 2,5 boilers & $13.600 \mathrm{~m}^{3} / \mathrm{h}$ \\
\hline 23. & $\begin{array}{l}\text { ZRD Poznań } \\
\text { ul. Berdychowo } 13 \\
\text { Gosp. Pomocnicze Zarządu Dróg }\end{array}$ & Bituminous paving plant & $100.000 \mathrm{~m}^{3} / \mathrm{h}$ \\
\hline 24. & $\begin{array}{l}\text { Czech Technical University } \\
\text { Praga }\end{array}$ & Boiler with fluidized bed & $2.400 \mathrm{~m}^{3} / \mathrm{h}$ \\
\hline 25. & Cukrownia „RACIBORZ” & $\begin{array}{l}\mathrm{OR} 32 / 25 \text { and } \mathrm{OR} 32 / 40 \\
\text { boilers }\end{array}$ & $210.000 \mathrm{~m}^{3} / \mathrm{h}$ \\
\hline 26. & $\begin{array}{l}\text { PPM „KLIMAWENTEX” Sp. z o.o. } \\
\text { Rzeszów }\end{array}$ & $\begin{array}{l}\text { Glass production line } \\
\text { and sand spreaders }\end{array}$ & $1.600 \mathrm{~m}^{3} / \mathrm{h}$ \\
\hline 27. & Jednostka Wojskowa Rząska k. Cracowa & WR 2,5 boilers & $26.000 \mathrm{~m}^{3} / \mathrm{h}$ \\
\hline \multirow[t]{2}{*}{28.} & \multirow{2}{*}{$\begin{array}{l}\text { Huta im. „CEDLERA” } \\
\text { Sosnowiec }\end{array}$} & OR 32/80 boilers & $180.000 \mathrm{~m}^{3} / \mathrm{h}$ \\
\hline & & $\begin{array}{l}\text { Second installation for } \\
\text { OR } 32 / 80 \text { boilers }\end{array}$ & $180.000 \mathrm{~m}^{3} / \mathrm{h}$ \\
\hline 29. & Cementownia Strzelce Opolskie & Process line & $6.400 \mathrm{~m}^{3} / \mathrm{h}$ \\
\hline 30. & $\begin{array}{l}\text { Odlewnia Żeliwa S.A. } \\
\text { Śrem, ul. Staszica } 1\end{array}$ & OKR 5 boiler & $25.000 \mathrm{~m}^{3} / \mathrm{h}$ \\
\hline 31. & $\begin{array}{l}\text { „EXBUD Tarnów” Sp. z 0.o. Tarnów } \\
\text { ul. Słoneczna } 30\end{array}$ & Boiler with fluidized bed & $7.320 \mathrm{~m}^{3} / \mathrm{h}$ \\
\hline 32. & $\begin{array}{l}\text { „EXBUD Tarnów” Sp. z o.o. } \\
\text { Oddział w Dębnie }\end{array}$ & Boiler with fluidized bed & $3.500 \mathrm{~m}^{3} / \mathrm{h}$ \\
\hline 33. & $\begin{array}{l}\text { „FIAT Auto Poland" } \\
\text { Tychy }\end{array}$ & WR 25 boiler & $140.000 \mathrm{~m}^{3} / \mathrm{h}$ \\
\hline 34. & $\begin{array}{l}\text { ZF „W. WRÓBLEWSKI” Warszawa } \\
\text { Janki, ul. Cracowska } 12\end{array}$ & PCO 60 boilers & $8.650 \mathrm{~m}^{3} / \mathrm{h}$ \\
\hline 35. & $\begin{array}{l}\text { PZL Warszawa } \\
\text { Wola }\end{array}$ & OKR and WR boilers & $100.000 \mathrm{~m}^{3} / \mathrm{h}$ \\
\hline 36. & ZGM „Ząbiec" & $\begin{array}{l}\text { Rotational bentonite } \\
\text { dryer }\end{array}$ & $33.000 \mathrm{~m}^{3} / \mathrm{h}$ \\
\hline
\end{tabular}




\subsection{Tecogen}

Tecogen is a consulting, research and engineering company, specializing in investment preparation and management, energy research and design. Under the Program, Tecogen worked on introducting to Poland a new technology for controlling and optimizing combustion processes in stoker-fired boilers. Another important contribution of Tegogen was development and implementation of shared savings agreements. Under these agreements, boiler house modernization is funded by a professional company ensuring efficiency improvement and a reduction in operating cost. The savings obtained are shared by the boiler house owner and the company, which in that way obtains reimbursement of the investment cost. To implement the project, a new Polish company under the name ECOGY was established in 1994. The shareholders of this company were:

- Tecogen, USA;

- Jaido, Japan;

- MPEC, Cracow; and

- Naftokrak-Naftobudowa, Cracow.

Jaido is a financial organization responsible for providing additional funds for the project. Naftokrak-Naftobudowa (NK-NB) is a company which specializes in assembly of industrial plants and facilities.

Initially, the project included the modernization of the large MPEC boiler house at Krzesławice. The boiler house had 4 PLM-2.5 stoker-fired boilers which produced processing steam for the neighboring industrial plant. The task of ECOGY was to install an air preheater, automatic control system, and flue gas recirculation system, and improve the efficiency of the existing cyclones. Two of the four existing boilers were to be modernized. However, due to a reduction in the steam demand of the industrial plant the modernization of the Krzesławice boiler house was cancelled. The company completed an analysis of the potential market and, from this, selected for modernization a boiler house of similar size owned by the Housing Cooperative in Wieliczka. Two WR-2.5 boilers were modernized at this location. A substantial efficiency improvement was obtained (after modernization the efficiency of the boilers was around $80 \%$ ) and particulate and $\mathrm{SO}_{2}$ emissions were reduced below permissible standards.

\section{Phase III Projects Which Were Not Completed}

Projects of three companies selected through the DOE solicitation in 1993 were stopped during their implementation, because the work scope could not be completed within the program timeframe. In addition, the need for these projects diminished with changing markets. In the 1990's, the market changed dramatically: environmentally clean fuel such as natural gas and heating oil became widely available. New products became available as did increased funding support for environmental projects. The number of boiler houses connected to the direct heating system or converted to gas was growing rapidly. First to be eliminated were large boiler houses, which had been candidates for modernization with the use of the American technology. Also, the number of operating solid fuel fired boiler houses, potential customers of improved coal fuels, decreased. These factors contributed to the early termination of the FFH Coal, TCS and Acurex projects described below: 


\subsection{EFH Coal Company}

The largest investment proposed by the American companies was to be a coal cleaning facility constructed by the EFH Coal Company. To implement the project, EFH along with MPEC and Naftokrak-Naftobudowa jointly established the ECOCOAL company. The company studied the feasibility of selecting a site for the planned processing plant. Due to difficulties with finding the proper site in a direct neighborhood of Cracow, a decision was made to locate the plant at the premises of Kazimierz Juliusz coal mine in Sosnowiec in Silesia. A leasing agreement was signed in Januay 1996. ECOCOAL, after having organized an open solicitation, ordered the legal and formal issues required for starting construction work to be arranged by ENG sp.z.o.o. The decision on conditions of land development and construction were obtained for the future plant in Sosnowiec. However, progress in the development of financing did not permit completion within the project deadline. Additionally, the market of potential customers in Cracow and the Cracow area decreased, and this called in question the profitability of the venture. Considering all this, the Bilateral Steering Committee did not approve a requested time extension for the EFH coal project. The project was closed, without obtaining the planned effect.

\section{$3.7 \quad$ TCS, Inc}

TCS, Inc. proposed modernization of stoker fired boiler houses through the use of micronized coal technology. The equipment required for coal micronization must be installed in the boiler house premises and coal must be micronized before it is burned in high performance, pulverized coal burners. This technology has several benefits: more complete combustion, lower ignition temperature, and a reduction of the amount of slag produced during combustion. The micronized coal is fed with pulverized limestone to assure elimination of $\mathrm{SO}_{2}$. Originally, the project was to be implemented at the military boiler house in Rzaska. However, due to the high cost of modernization and the limited financial capacity of the Polish partner (Wojskowy Zarząd Kwaterunkowy Budowlany) this site was rejected. The next proposed location was the boiler house of the Horticulture Production Plant in Krzeszowice, a Cracow neighborhood. TCS proposed constructing a new boiler house, fired with micronized coal, the primary heat source for the horticulture production and residential apartment buildings. The old boiler house fired with mazut (heavy) oil was planned to be used during peak periods. However, also in this case, the cost of the planned investment proved to be too high for the Polish partner. No alternative site was found for the TCS installation. The pulverized coal burners proposed by TCS could not be directly adapted to existing boilers or to new Polish boilers. The necessity to replace the boilers and use imported equipment caused, in each case, a significant increase in project capital cost. The analyses done proved that the planned investment cost could not be accepted by the Polish partners. A decision was therefore made by the Bilateral Steering Committee to terminate the project.

\subsection{Acurex Environmental Corporation}

Acurex Environmental Corporation proposed to produce smokeless briquettes for home stoves, based on company's proprietary technology. The briquettes would replace coal and reduce emission of pollutants by $70 \%$. The production capacity planned in this project would meet $50 \%$ of Cracow demand for home stove fuel. This program included a testing/development phase during which Acurex workcd with AGH to optimize briquette 
formulation for specific Polish components. A large test batch of fuel was produced in a manufacturing plant in Bogdanka and tested in the AGH laboratory. Briquettes were delivered to 200 apartments, to collect opinions from users. The briquette price proposed by Acurex was not competitive compared to the local coal price and the company did not find a Polish a partner interested in its production. The Bilateral Steering Committe made a decision not to allow the Acurex project to be completed as originally planned. The primary reason for this decision was the lack of required "cost-share" funding to complete construction of a production facility. 


\section{Implementation Plan for Reduction of Low Emission Sources in Cracow}

During the development of an implementation plan for the reduction of low emission sources in Cracow, Biuro Rozwoju Krakowa developed tools for collecting, analyzing and presenting information on low emission sources. These tools include:

- Boiler house database;

- Buildings database;

- Technical infrastructure database;

- Geographical Information System (GIS) for the graphic presentation of the above information on city maps of different types; and

- Spreadsheet models for comparison of various types engineering options.

The collected information and processing tools provided a basis for the development of a "Master Plan" for the reduction of air pollution from low emission sources in Cracow.

\subsection{Analytical Tools}

\subsubsection{Boiler House and Buildings Data Bases}

A comprehensive inventory of the local boiler houses and heating systems for residential buildings was prepared for the first time in a comprehensive way in 1990. As a result of a door-to-door inventory the basic part of the database on the low emission sources was developed. This served as the source material used during the implementation of the Polish-American program on low emissions in Cracow. A survey form, adapted to requirements of computer analysis was prepared for the boiler houses or the individual heating systems. The boiler house survey included information on boiler house location, boiler house owner and supervisor, boiler house type, number and type of boilers and their relevant parameters, type of fuel and annual consumption, data on emission control equipment, and emissions. Surveys for individual heating systems included data on site location, owner and supervisor, type of heating system (stoves, individual central heating, individual gas heating, electric heating), heated arca, avcrage height of buildings floor, and number of floors. All data collected by the surveyor has been put into a computer database (dBase). According to the collected data at the end of 1990, 1344 local boiler houses operated in Cracow of which $84 \%$ were solid fuel-fired boiler houses. More than 25,700 buildings were inventoried. These buildings were found to contain more than 99,990 coal stoves.

Since 1990 dramatic and essential changes have taken place in all areas of public, economic, and legal functioning of the economy, that necessitated updating the database. The first update of the database was done at the turn of 1993-1994, the next at the end of 1997. Since 1996, Access has been used as the data base software.

As of the end of 1997 there were 972 boiler houses in Cracow with a total rated capacity over $787 \mathrm{MW}$, including 489 solid fired-boiler houses with a total capacity over 539 MW. The majority of the installed boilers at the time of this survey were solid fuel-fired 
$(1,248)$. One hundred and fourty two (142) boilers had mechanical grates installed. Seventy-nine percent $(79 \%)$ of the stoker-fired boilers had air pollution control devices, usually cyclones and multicyclones. Only 33 hand-fired boilers $(2.6 \%)$ had air pollution control devices. Among fixed grate boilers ECA IV and KZ-5 were the most common types. Among boilers with mechanical grate the most popular were the WCO, PCO, WLM, and PLM boilers.

With regard to boiler size, small boiler houses, with a capacity up to $500 \mathrm{~kW}$ (around $80 \%$ of all boiler houses) are most prevelant. A few larger boiler houses, with a capacity over $1000 \mathrm{~kW}$ are mostly located some distance from the city center. These large boiler houses represent around $70 \%$ of the total installed capacity. Solid fuel-fired boiler houses used over 147,000 metric tons of fuel annually, mostly fine coal and coke. In 41 boiler houses, 106 thousand metric tons of fine coal was burned and in 378 boiler houses 32,000 metric tons of coke was burnt. Forty-three (43) boiler houses burn 6,600 metric tons of coal and in 27 boiler houses 2,500 metric tons of coal and coke mixture was used. A division in the city regions is as follows: Old Town region -14 boiler houses with a total rated capacity of $5,433 \mathrm{~kW}$, area between the $1^{\text {st }}$ and $2^{\text {nd }}$ circular rings: 127 boiler houses with a total rated capacity of $48,091 \mathrm{~kW}$, area outside the second circular road: 348 boiler houses with a total rated capacity of $485,945 \mathrm{~kW}$.

In 1997 there were still 78,000 coal stoves and home heating systems in Cracow. It is estimated these systems used around 60,000 metric tons of coal annually.

\subsubsection{Geographical Information System as a Planning Tool}

Under this program, a system of spatial information on boiler houses and the technical infrastructure was developed. This Geographical Information System (GIS) enables data to be obtained, processed, and accessed in a way which contains spatial and descriptive information on the sites located in the space covered with this system. A basis for this system is a database on low emission sources, data bases on technical infrastructure and the current development plans. The GIS allows spatial visualization of the collected data on the maps. Data has been presented on raster maps in 1:2000 scale (the Cracow area includes 200 such maps) in 1:10,000 scale (35 maps) and on the scheme of the main traffic system in Cracow.

The system was developed based on the Arc View program, which is a complete program to view, analyze (sorting, logical queries, statistic reports) and process data for publication. The program combines traditional analytical tools such as spreadsheets and charts with presentations on the maps. The GIS system on boiler houses and Cracow technical infrastructure allows the user to analyze and graphically present the following information:

- boiler house location;

- information on the boiler house owner and user;

- boiler house rated capacity; 
- data on installed boilers;

- data on type and amount of fuel;

- data on the use of the produced heat;

- data on air pollution control devices;

- parameters of the heating network (length, diameters, existing and designed heating network);

- parameters of the gas network;

- parameters of the electric network.

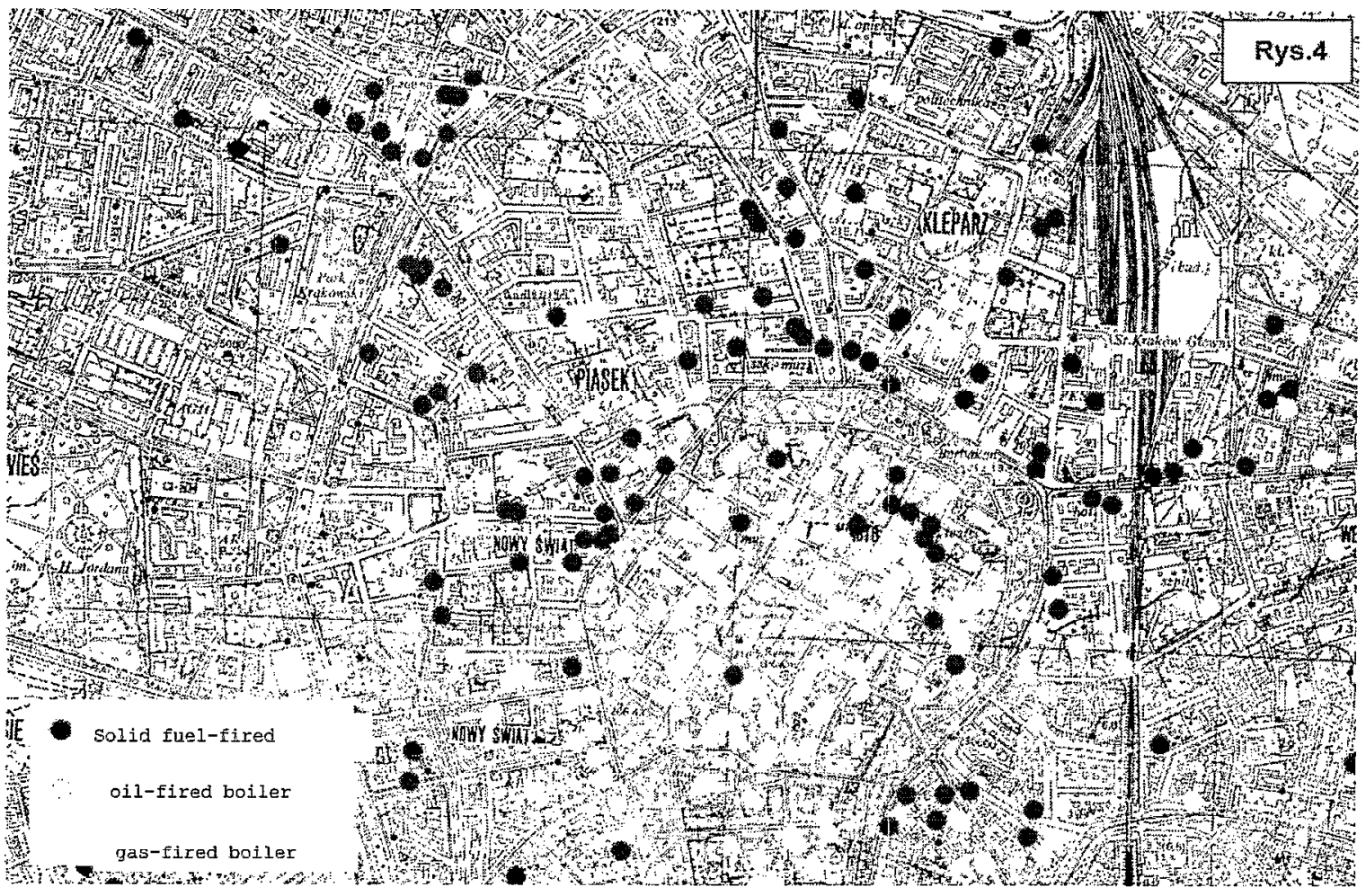

Figure 4-1 Example use of the Geographic Information System (GIS) to show locations of local heating boilers around the city center.

Analysis and graphic interpretation of data can be done for selected groups of objects. The selection can be done either through marking the respective records in an attribute table or through marking the objects on the graphic presentation. The GIS was used extensively in the development of implementation plans for the reduction of low emission sources in Cracow.

\subsubsection{Spreadsheet Model to Compare Technical Options}

To compare the options for reducing air pollution from low emission sources a spreadsheet model was used. The spreadsheet model is a tool for rapid options analysis, used for making strategic decisions regarding city regions, quarters, and the entire Gmina 
(municipality). It uses averaged values of capital costs and unit emissions. Therefore it can not be used for a specific investment project.

The spreadsheet program allows calculation, at the baseline conditions, and after a specified conversion project, of the followings values: emissions of specific pollutants, annual user cost (fuel cost + operating cost + maintenance cost + other costs), and capital costs. To facilitate options comparison the calculated values have been expressed based on the criteria called "user annual combined cost per ton of reduction of equivalent emission". This criteria can be defined by the following formula:

$$
\frac{S K R U}{\Delta E R}=\frac{0.0888 \times N I K+\Delta R K U}{\Delta E R}
$$

where:

SRKU - user annual combined cost

NIK - conversion capital cost

0.0888 - coefficient defining amount of annualized capital costs assuming a project life of 30 years and an interest rate of $8 \%$

$\triangle \mathrm{RKU}$ - change of user's annual cost after conversion

$\Delta \mathrm{ER} \quad$ - change of equivalent emission after conversion

The lower the value, the better the option.

The results of the spreadsheet model also present two additional factors:

- "capital costs per ton of equivalent emission reduction $\mathrm{NIK} / \Delta \mathrm{ER}$ ". The lower the value, the better the option;

- "change of user's annual cost after conversion per ton equivalent emission reduction $\triangle \mathrm{RKU} / \triangle \mathrm{ER}$ ". Again, the lower the value, the better the option.

\subsection{Implementation Plan}

An implementation plan for the elimination of low emission air pollution in Cracow was developed by BRK as part of this program. The development of the plan was a continuation of work carried out in 1991-1995 and was based on information and experience collected during this period. To develop this plan electrical, gas, and district heating supply systems were analyzed relative to their use for elimination of low sources of air pollution.

The implementation plan for reducing low emission sources was prepared in three parts for three areas of Cracow: 
- Part I Old Town area (study developed in December 1996);

- Part II area between the $1^{\text {st }}$ and 2 nd circular road (study developed in June 1997);

- Part III area between the $2^{\text {nd }}$ circular road and administrative borders of the town, (study prepared in July 1998).

The basic information used in the development of the plan was that contained in the data base on boiler houses and buildings, the spreadsheet model for comparing the technical options and the GIS system for graphic presentations. Based on the results from the Phase I Program, the selection of technical options for the elimination of low emission sources was done, to use them in further analysis.

According to the results of this analysis, the most effective is conversion of coal, coke or coal-coke mixture-fired fixed grate boiler houses through the replacement with gas boiler houses or connection to the district heating network. Another very effective option is modernization of stoker-fired boilers. A less effective option is elimination of coal stoves both through replacement with gas or electric heating. The majority of conversion options result in a reduction in operating cost. An exception is the conversion of stoker fired boilers and the replacement of coal stoves with electric heating. The highest investment cost is in the case of replacement of home heating. Replacement of coal stoves with gas home heating requires construction of central heating installation and in many cases flue gas removal and ventilation systems. Replacement of coal stoves with electric heating requires modernization of the building's electrical system and modernization of the local electrical grid. In the case of boiler houses elimination, the building's electrical system the highest investment cost is for gas conversion, the lowest for connection to the district heating network.

To compare different types of conversions the aggregated criterion "total annual users cost per one ton of equivalent emission "SKRU/AER" was used. The lower the value of this criterion, the more favorable the option.

The most effective method of eliminating solid fuel-fired boiler houses in the Old Town section of Cracow is by conversion to gas. The increased demand for gas can be handled by the existing supply system consisting of medium pressure gas lines, arranged annularly and in the Planty (circular park around Old Town) and 8 reduction stations. All healing systems with small home boilers burning coal in Old Town should be converted to gas. It is estimated that around $20 \%$ of coal stoves will be replaced with gas heating. Conversion of home heating to gas will be possible without modernization of the existing network. The remaining $80 \%$ of coal stoves will be converted to electric heating which will require the construction of 11 new transformer stations and extension of the medium and low voltage networks.

In the arca of the $2^{\text {nd }}$ circular road, the solid fuel-fired boiler houses will be eliminated through conversion to gas or connection to the municipal heating network. In 1997-98 the extension of the district heating system in the regions of Kazimierz, Politechnika Krakowska, Nowy Kleparz, and Michalowskiego and Czysta Streets as recommended in 
the Implementation Plan, was completed. Connection of several other boiler houses located in the neighborhood of the existing heating system is possible in the future. It was determined that it was more practical to convert the remaining boiler houses to gas. The increased demand for gas supply will require the construction of 3 new 2nd stage reduction stations (region of Politechnika, Piekarska str., Sniadeckich str.) along with medium pressure pipelines and modernization of 2 existing 2 nd stage reduction stations (Gazowa and Szewska streets). Also necessary is extension and modernization of the low pressure gas network. It is estimated that around $20 \%$ of the coal stoves will be replaced by gas heating. Replacement of home heating with gas will be possible without modernization of the existing network. The remaining $80 \%$ of coal stoves will be converted to electric heating. The existing electric power system is not adapted for supplying energy for heating purposes. Modernization and extension of the high and low voltage distribution networks is necessary.

In the area between the $2^{\text {nd }}$ circular road and the administrative border of the City, 182 boiler houses with an overall capacity of $210 \mathrm{MW}$ were qualified for elimination through connection to the municipal district heating system. One-hundred-two (102) boiler houses with a designed output of $156 \mathrm{MW}$ are located in the supply area of the ECKSA Power Plant. Eighty-two (82) boiler houses with a designed output of $54 \mathrm{MW}$ are located in the Skawina supply area. The existing system is not sufficient to supply heat to each part of this area. An extension of the system is necessary including construction of the following main sections of heating network:

1. Junction of the EC Skawina main line with the Southern main line (region of Wadowicka-Kurdwanow residential complex);

2. Junction of the Eastern and Northern main lines in the region of Srebrne Orly and Prądnik Czerwony;

3. Junction of the Western and Northern main lines in the region of Marchewczyka Street;

4. Construction of a heating network in region of Makuszynskiego Street along with a junction in region of Zlota Jesien residential complex;

5. Construction of a heating pipe line from the main line in Przewoz region to the boiler house Obroncow Modlina (this will result in the elimination of the boiler house);

6. Construction of a branch from EC Skawina main line to Pychowice region (Jagiellonian University campus and Military Unit);

7. Extension (increase of capacity) of the existing network at Praqdnik Bialy residential complex to enable heat supply to Gorka Narodowa.

Elimination of the boiler houses requires the construction of connecting pipelines from a dozen to even several hundred meters long. Each decision to connect a local boiler house 
to the district heating system is based on an economic analysis. The proposed extension of the heating network has created the possibility to eliminate boiler houses in the following regions located near the area supplied from ECKSA: region of Soltysowska Street, Makuszynskicgo Strect, residential areas Ugorek, Olsza, Osiedle Oficerskie, Pradnik Bialy, Azory, Krowodrza, Bronowice, Krolewska and Wroclawska streets, region of Industrial Complex in Plaszow, residential complexes Prokocim, Na Kozlowce, Zadworze, Plaszow and Wielicka Street. In the area supplied from EC Skawina, the extension of district heating was proposed in the following regions: Stare Podgorze, Zablocie, Lea-Kunickiego streets, residential areas Debniki, Podwawelskie, Pychowice, Mateczny traffic circle, Fredry, Wadowicka Street, and the region of Borek Falecki and Skosna and Zawila Streets.

Under this effort two boiler houses with stoker-fired boilers with a total capacity of 85 MW at Lindego and Pradnicka streets were modernized with continued operation on coal. Modernization of the boiler houses included installation of boiler control and combustion process optimization equipment, installation of variable speed pump drives and installation of equipment for automatic control of heat source output (depending on the changing requirements of customers).

Three boiler houses, with a total output of $18 \mathrm{MW}$, were eliminated at 20 Makuszynskiego Street ( 2 boiler houses) and at Lowinskiego street. They were replaced by a local heat source with a capacity better matched to the real, current, demands of customers.

A total of 164 solid fuel fired boiler houses were qualified for gas conversion - 106.MW of total capacity after conversion. In the last few years, the heat network was extended significantly, the number of customers of gas supply increased, including use of gas for heating. The extended plan of reconstruction and renovation of the municipal network and other facilities, implemented in recent years by the gas utility, with at the same time decrease of gas consumption by the industry, resulted in better possibilities to use it for heating purposes. Thereupon many local boiler houses were converted to gas. The existing gas system assures gas supply to the existing customers and still has some reserve capacities. To assure supply of the increased amount of gas for the boiler houses and home heating systems there is a necessity to locally modernize the existing system through the reconstruction and extension of the medium pressure gas network and construction of new reduction stations. Upgrades to the system include:

- Construction of 1 st stage reduction stations in the region of Gorka Narodowa and Przewoz;

- Modernization of the $1^{\text {st }}$ stage reduction stations at Mistrzejowicka str., Zawila str., and in Kryspinow;

- Construction of medium pressure gas pipelines from 1the st stage reduction stations at Gorka Narodowa, Przewoz, Kryspinow and at Zaslawicka, Gierymskich and Radzikowskiego Streets; 
- Reconstruction of medium pressure pipelines to 2 nd stage reduction stations at Chelm, in region of Wadow, and on Fredry Street;

- Construction of reduction stations for the brick yard's boiler house in Zeslawice, in region of Praska-Tyniecka streets, for the MPK boiler house at Rzemieslnicza, and for boiler house in Institute for Nuclear Physics;

- Modernization of the reduction station in Chelm and the "Kabel" Factory (in progress).

It will also be necessary to upgrade the low pressure pipe line system.

It is estimated that in this area around $60 \%$ of the coal stoves will be replaced by electric heating. Due to the magnitude of this task, general reconstruction and modernization of the existing system of electric power supply is required. This involves mainly the medium and low voltage supply system because these systems, planned in the past, did not consider broad scalc use of clectric energy for heating purposes. One must also include the fact that the problem of increased consumption of electric energy refers also to the industrial-distribution system of the highest voltage of $110 \mathrm{kV}$.

The region least equipped to handle the conversion to electrical heating is the Podgorze quarter -region "stare Podgorze". This region has the highest concentration of coal stoves and at the same time there are no main points of $110 / 15 \mathrm{kV}$ supply. This area of the city is supplied with electric power from a station located within this quarter and in Srodmiescie Quarter (GPZ Dajwor). Solution of the problem of supply in this area in electric power requires construction of around 56 new transformer stations $15 / 0.4 \mathrm{kV}$. The demand for electricity will be covered based on the existing GPZ's 110/15 kV "Dajwor", "Ruczaj" and "Wola Duchacka". The construction of the new stations, planned by the Electric Utility in Kraków : "Kobierzyn", "Pychowice",Dabie" and "Kurdwanow" will allow them to take on a part of load from the stations mentioned above.

This reserve can be used for electric heating. In the remaining quarters, besides the earlier mentioned construction of main supplying points in region of the Traffic Center, Dabie and Salwator, significant extension of the system on the side of medium and low voltages is necessary.

\subsection{Recommendations for the City Authorities}

There are several barriers which impede elimination of low emission sources in the area between the second circular road and administrative borders of the city. These include: 
- Many of the boiler house owners do not have financial resources for conversion;

- Many of the residents do not have financial resources for conversion of coal heating to gas or electric heating;

- The electrical and gas distribution infrastructure in some regions of the city is not sufficient, there are problems with extension of the district heating systems due to limited resources of the utilities, difficulties with finding locations for new infrastructure, and long formal-legal procedures for investments;

- The dominant trend in elimination of home stoves is their reconstruction to electric heating. The electrical power system is not adequate to supply a large group of new customers of electric heating. In the future, most of the stoves, especially those located in the center of the city will have to be eliminated through the conversion to gas - an expensive option;

- The existing solid fuel- fired boiler houses are mostly small (capacity within 100$300 \mathrm{~kW}$ ). Energy power companies are not very much interested in such sites. The investors have difficulties raising funds from external sources due to lack of credit and complicated procedures for obtaining financial resources.

Municipal authorities can help overcome these barriers by implementing the following activities:

- Recognition that the issue of low emission sources is one of the priorities in the Municipality's policy, introduction of appropriate entries in City Council resolutions and regulations concerning allocation of financial resources by Gmina and Voivodship Environmental Protection Funds,

- Undertaking informational activities on the possibilities and benefits of eliminating the low emission sources,

- One of the informational activities recommended is establishing an Energy Counseling Post, where the residents and the boiler house owners could be provided with basic information on the possibilities of obtaining funds from the external sources, methods of energy efficiency, and environmental effects.

- Support agreements between boiler house owners leading to joint implementation of the conversion of solid fuel-fired boiler houses to gas. A leader of such agreements can be an enterprise interested in selling energy or equipment. Such agreements would make possible the submission of joint applications for financial assistance and would facilitate negotiations with suppliers and construction companies. 
- Maintain incentives developed by the city authorities in the form of donations from the Gmina Fund for Environmental Protection and Water Management.

- As a temporary solution it would be advisable to eliminate from the market the poor quality coal used by home stoves and boiler houses.

- As a complementary solution for a process of elimination of solid fuel-fired stoves and boiler houses, energy efficiency measures should be strongly promoted, including energy conservation measures in buildings. 


\section{Implementation of Phase IV}

\subsection{Conversion of Solid Fuel-Fired Boiler Houses}

\subsubsection{Description of the Project}

In the historic town center, within the second circular road, over 100 solid fuel-fired boiler houses were in operation during the 1997/98 heating season. They were a significant source of local air pollution. The owners of the buildings in which the boiler houses are located are: Gmina Kraków, the State Treasury, local companies, and private citizens. Buildings owners were not able to modernize the boiler houses on their own due to:

- Lack of financial resources;

- Difficulties in obtaining funds for modernization from external sources;

- Lack of technical preparation for implementation of such investments.

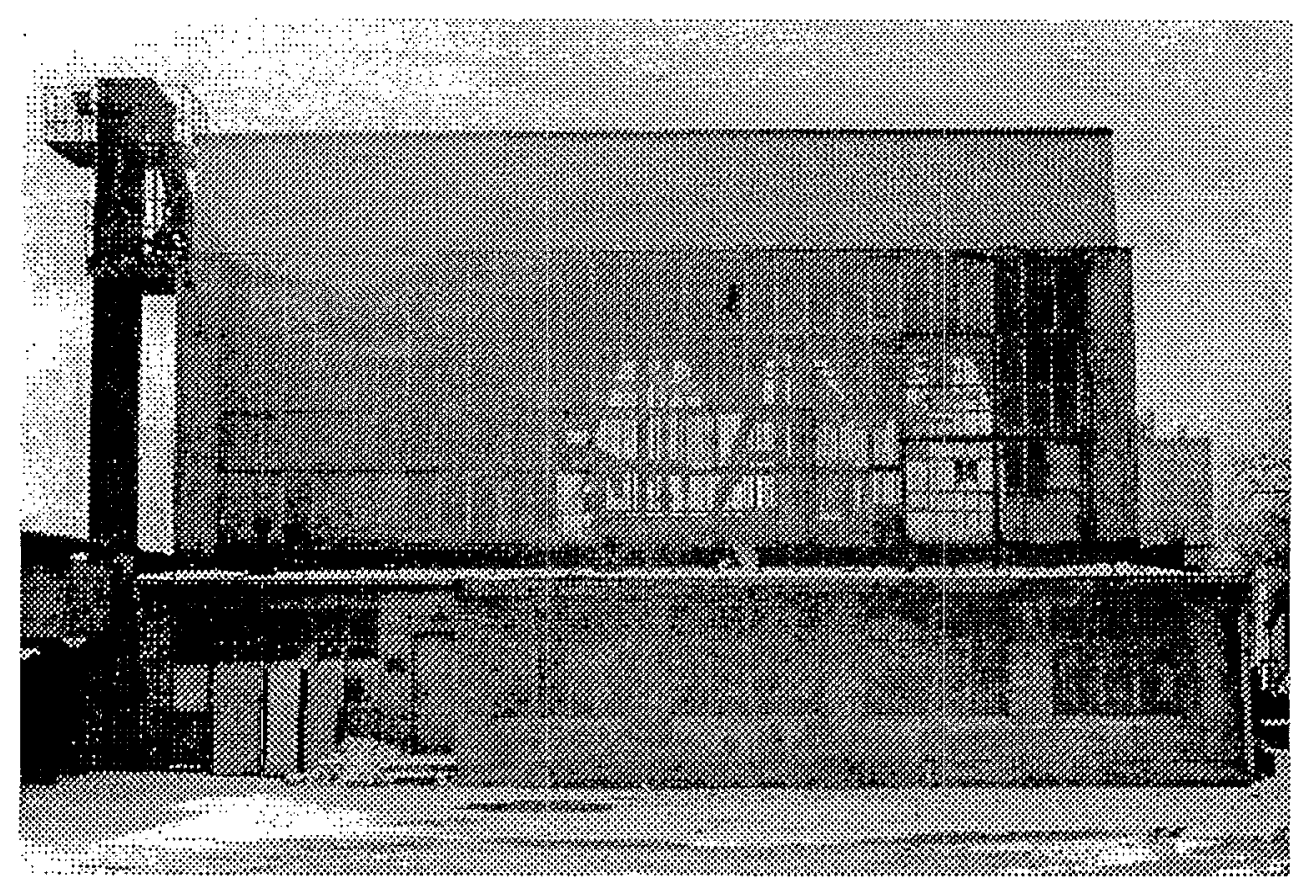

Figure 5-1. Typical coal-fired boiler house with stoker firing

The only way for quick elimination of the environmentally burdensome solid fuel-fired boiler houses was assuring assistance in the elimination of these barriers.

Under this program a project of assistance was directed towards the owners of the solid fuel fired boiler houses that were willing to convert them. The assistance was both organizational and financial in nature. The organizational assistance included: information activities, preparation of the technical documentation (design studies) obtaining building permits on behalf of the owner, submission of applications to the 
environmental funding: organizations, help in selection of contractors, coordination of supplies, and technical supervision of investment implementation. Financial assistance included funding of the preparatory and design plans and purchase of the basic equipment required for the new heat source.

The objective of the program was the elimination of the solid fuel-fired boiler houses through connection of the boiler houses to the district heating system or by conversion of the boiler houses to gas. The program was available to all boiler house owners, irrespective of their legal status.

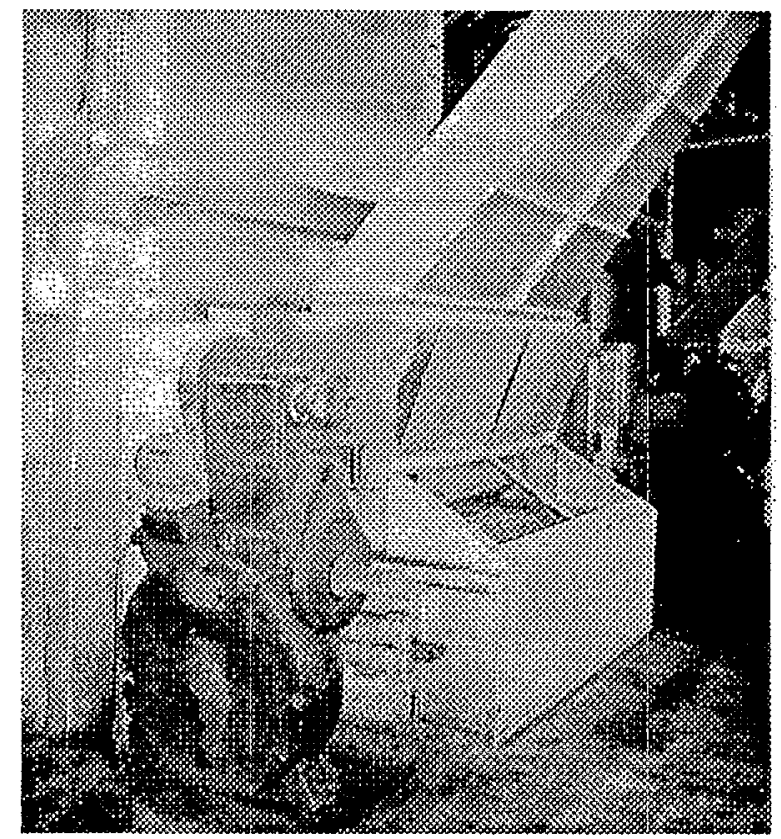

Figure 5-2. Stoker fired boiler. Coal chute, moving grate, and drive.

Criterion for selecting boiler houses to participate in the program included:

- Location, (i.e. distance from the city center);

- Clear legal status of the site;

- Ability to complete investment within the planned schedule.

A priority was given to upgrading the boiler houses located in the central part of the town and to the sites owned by Gmina.

The BSC specified that funding obtained directly from the program could be used to subsidize no more than $50 \%$ of the cost to modernize/convert the boiler house. The remaining $50 \%$ of the investment cost had to be secured by the Polish project participants. The project of boiler house elimination was coordinated locally by BRK. BRK's services included public information, inviting the boiler house owners and the third party investors to participate in the program, negotiations with the boiler house owners, preparation of the applications to the project co-funding organizations, 
preparation of the technical documentation, collecting technical documentation required for obtaining building permits, selection and purchase of equipment, coordination of supplies, technical supervision of the project implementation, public information and general project management. Two forms of activities were used by BRK:

- Direct assistance for boiler house owners. The boiler house owner, through BRK, could obtain a subsidy directly from the program in an amount up to $50 \%$ of the investment cost for upgrades. This subsidy was intended for purchasing the basic equipment and to cover the cost of design work done by BRK. The remaining part of the investment cost had to be secured by the site owners. These funds were allocated for use in funding the purchase of auxiliary equipment, assembly of equipment, placing of sanitary and electric installations, and execution of construction works.

- Assistance provided to companies responsible for conversion as "third party investors". The boiler house owners could commit the work connected with supplying heat to the building to a third party investor. The "third party investor" undertook the task to supply heat to the building and to complete the modernization works directed towards eliminating the solid fuel-fired boiler house.

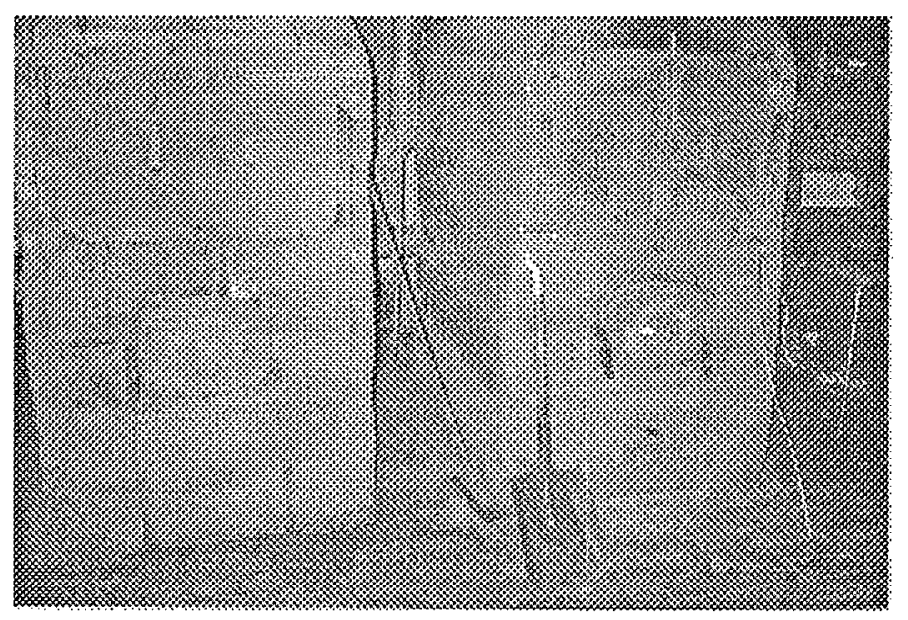

Figure 5-3. Hand-fired coal boiler and typical heat exchanger station which replaced it

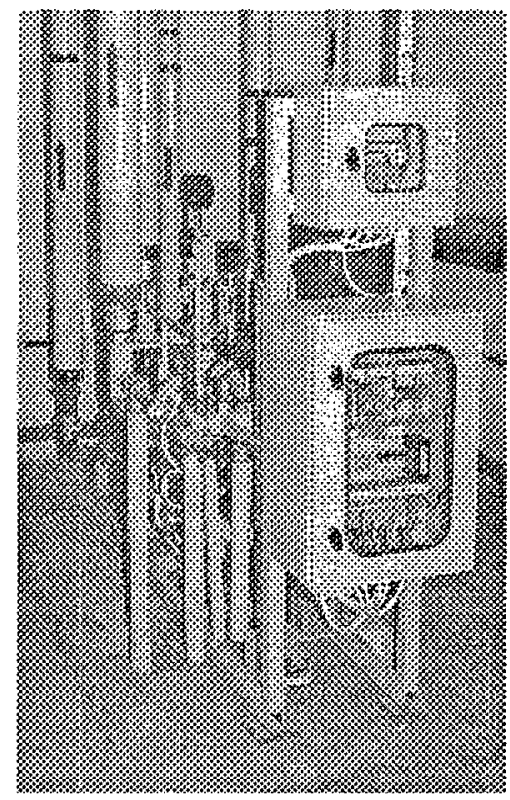

The "third party" handled all organizational, technical and financial arrangements. The building owner was responsible for providing the space to be used to house the new heat source and for the preparation of central heating and hot water installations for connection to the new heat source. The site owner, was responsible for providing, free of charge, the space for installing the new heat source and was committed to buying heat for a period of ten years. 
Two companies that have been active in the Polish energy market for many years and have successfully converted many boiler houses acted as third party investors. These companies were MPEC and ECKSA.

The of the solid fuel-fired boilers was accomplished by either converting them to gas or by connecting them to the municipal district heating system. In exceptional cases, when connection to the DHS was not economically feasible or it was not possible to convert to gas due to a lack of supply of gas, oil-fired boiler houses were constructed.

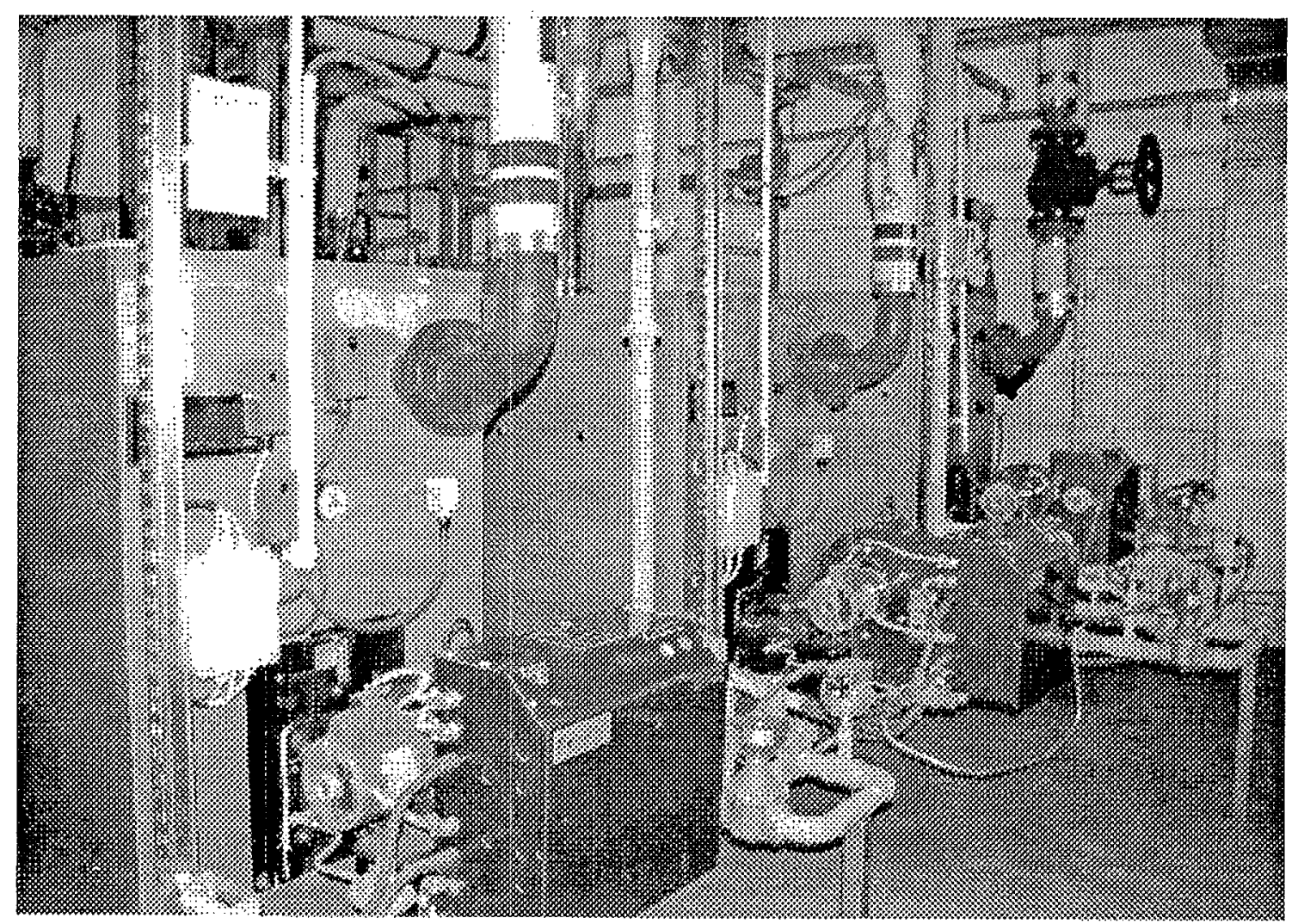

Figure 5-4. New gas-fired boiler room

\subsubsection{Scope of Work}

During the time period, 1999 to 2000 , the solid fuel boiler-house conversion project handled 118 boiler house conversions, including 81 boiler houses in 1999 and 37 in 2000 . Seventy-five (75) gas fired boiler houses were also constructed 54 boiler houses in 1999 and 21 boiler houses in the year 2000 ). The boiler houses were constructed by:

- MPEC

- ECKSA

- Boiler house owners
- 34 boiler houses;

- 6 boiler houses;

-35 boiler houses. 
Total capacity of the newly constructed gas boiler houses is $17.6 \mathrm{MW}$. The average efficiency of combustion increased from around $65 \%$ with the solid fuel-fired boilers to over $90 \%$ for the new gas-fired boilers. Forty-three (43) sites were connected to the municipal district heating network (27 sites in 1999, and 16 sites in 2000). Connections were constructed by:

- MPEC

- ECKSA
-40 sites;

-3 sites.

The total capacity of the sites connected to the DHS is 36.4 MW. The total capacity of the boiler houses eliminated under the Program is 98.2 MW (27.5 MW in 1999, and 70.7 MW in the year 2000). Around 11,500 metric tons/year of coke and 15,200 metric tons/year of coal fines had been burned in the boiler houses that were eliminated from use.

\subsubsection{Project Implementation}

Implementation of the project was done in 3 stages: 1) defining the project assumptions and ground rules, 2) preparation and implementation of investment in the year 1999 and 3 ) preparation and implementation of the investment in the year 2000. The schedule of the investment implementation was as follows:

December 1997

Preliminary decision of the Bilateral Steering Committee January-April 1998

Preparation of the project assumptions and ground rules May 1998

Decision of the Bilateral Steering Committee on allocation of the funds for assistance to be provided to the owners of the solid fuel fired boiler houses to be eliminated August-September 1998

Public information on the project, inviting the boiler house owners and the third party investors to participate in the project.

October-November 1998

Negotiations with the boiler house owners, qualifications of the sites

December 1998 - March 1999

Selection of major equipment suppliers through an open bid procedure April-June 1999

Preparation of technical documentation, collecting of documents required for obtaining building permits, preparation of the applications to co-funding organizations

July-September 1999

Efforts to obtain building permits

August-November 1999

Assembly and start-up of the equipment

September-October 1999

Renewed invitations to the boiler house owners and the third party investors 
November - December 1999

Negotiations with the boiler house owners, qualification of sites for the year 2000 implementation

March-June 2000

Preparation of technical documentation, collecting of documents required for obtaining building permits, preparation of the applications to co-funding organizations

July-September 2000

Efforts to obtain building permits

August - November 2000

Assembly and start-up of the equipment

The work financed from the American funds such as the technical portion of the project and the purchase of the basic equipment, was completed on August 31,2000. After that date activities financed and implemented by the Polish participants such as assembly and start-up of equipment were completed. In some cases, it became necessary to extend the date of completion due to prolonged procedures for obtaining building permits or due to lack of funding

Program funds from American sources were not used to cover more than $50 \%$ of the investment cost for upgrading a boiler house facility. The remainder of the funding was provided by the Polish participants of the Project. These were funds provided by the companies participating in the project as third party investors including MPEC and ECKSA, funds of the boiler house owners, or funds provided by the Gmina and Voivodship Funds for the Environmental Protection and Water Management.

According to the resolutions of the City Board of Krakow the funds from the Gmina Fund for Environmental Protection and Water Management were allocated for work done to convert solid-fuel fired boiler houses to gas.

The funds from GFOSiGW were allocated to complete financing required for the 19 boiler houses converted to gas in 1999 and the 11 boiler houses converted to gas in 2000 . These were the boiler houses located in the buildings owned by Gmina Kraków or by private owners. The funds from GFOSiGW were used for boiler disassembly, for installation of new assemblies and modifying existing equipment to be compatible with a new heat source. The owners of two boiler houses (1 in 1999 and 1 in 2000) received subsidies from the Voivodship Funds for the Environmental Protection and Water Management.

In the solid fuel-fired boiler house conversion project, wherever possible, American equipment was used in the conversion work. The American equipment was purchased under the condition that service and spare parts would be locally available and the offered price had to be competitive. Through an open bidding procedure, boilers were obtained from Mestec Inc. (Massachusetts), heating equipment from Power Flame (Kansas), and burners and controls from Johnson Controls Inc. Additionally, the equipment for the gas fired boiler houses was purchased from Polish manufacturers (chimney inserts) and European manufacturers (pumps, membrane vessels). Preinsulated pipes and compact 
heat exchanger nodes required to make connections to the DHS were also bought from theses suppliers.

\subsection{Modernization of the Heating System Management in Children's Hospital}

Under the American-Polish Program to Reduce Low Emissions sources in Cracow, a program to modernize the heating system in the Children's Hospital of the Collegium Medicum of the Jagicllonian University was developed. This effort was connected with the elimination of the Boiler House at Mala Gora, which was a major local pollution source. The existing system for supplying heat was inefficient, uneconomical and source of pollution that had to be eliminated.

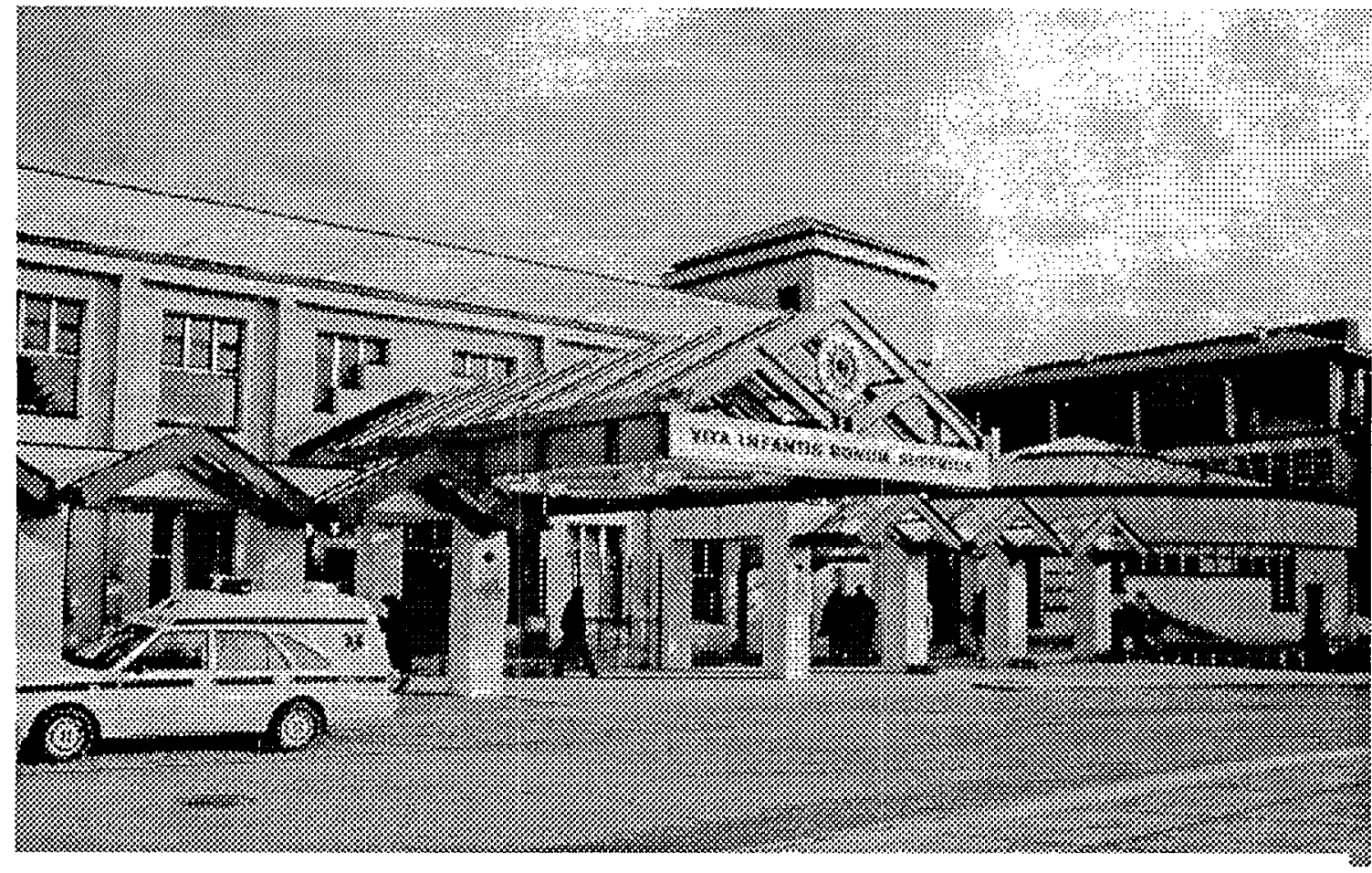

Figure 5-5. Entrance to the Polish-American Children's Hospital

\subsubsection{Description of the Current Status}

Up to 1999, the Children's Hospital of the Collegium Medicum of the Jagiellonian University was supplied with heat from three sources:

- The municipal district heating system;

- A hot water boiler house firing fine coal;

- A gas-fired steam boiler house. 
Heat from the municipal district heating network was previously supplied from chamber KXIV of the "Southern" mainline via a pipeline constructed using channel technology. The pipeline was not owned by MPEC. The pipeline ran in part at a depth of about $5 \mathrm{~m}$, below a supermarket parking lot.. In the event of ruptures, repairs were extremely costly and very difficult. The municipal district heating network operates at temperature ranges of 150/80 ${ }^{\circ} \mathrm{C}$ and are controlled to follow changes in ambient temperature. In the future, the operating temperatures will be reduced to $135 / 65^{\circ} \mathrm{C}$ in the heating season. Outside of the heating season the operating temperatures are $65 / 35^{\circ} \mathrm{C}$ for shell and tube heat exchangers and $65 / 25^{\circ} \mathrm{C}$ for plate heat cxchangers.

The hot water boiler house was located at Kraków-Biezanów at Mala Gora 8. It was equipped with three stoker-fired WLM-5 type boiler units with a combined peak capacity of 17.5 MW. The boiler house produced hot water at $175^{\circ} \mathrm{C}$ and $1.0 \mathrm{MPa}$, that is subsequently cooled in a set of evaporators to $135^{\circ} \mathrm{C}-150^{\circ} \mathrm{C}$. This boiler house provided hot water for the system of central heating and ventilation and to produce steam in evaporators. These boilers were very worn, suffered frequent failures, and constituted a source of considerable pollution.

Hot water was supplied to the hospital via a $2.5 \mathrm{~km}$ long $300 \mathrm{~mm}$ diameter pipeline. The pipeline suffered frequent failures especially at welded joints, that was probably caused by thermal expansion. The pipeline's insulation was in bad shape and resulted in considerable heat losses. Low efficiency boilers and a very old district heating network, combined with the need of maintaining water temperatures of $175^{\circ} \mathrm{C}$ (due to the need of generating $0.5 \mathrm{MPa}$ steam in evaporators) led to considerable heat losses and high costs of energy production and supply.

The steam gas-fired boiler house, located near the Hospital's laundry, was equipped with three 20 year old boilers with a capacity of $0.6 \mathrm{MW}$ each. The boiler house produced steam at 8 bars pressure. The boilers were considerably worn but were used as a reserve source for the existing evaporators in the event of a failure at the Biezanów boiler house.

The operating services in the Children's Hospital battled against the following problems:

- High failure frequency in Biezanów boiler houses;

- Low efficiency of energy production;

- High emissions of pollutants causing problems to the residents of the neighboring residential area;

- Frequent leaks in the $2.5 \mathrm{~km}$ long pipeline connecting the boiler house with the hospital premises;

- Significant transmission losses;

- Defective engineering;

- Lack of automatic control of temperature at the customer side. 


\subsubsection{Scope of Work}

According to the design concept developed for the modernization of the heat management system the following work has been completed:

- All compatible hospital facilities have been connected to the municipal district heating system. Total capacity of the connected facilities is around $9.6 \mathrm{MW}$;

- The existing connecting nodes were replaced with compact heat exchanger nodes (6), equipped with automatic controls;

- steam boiler house of 2.6 MW capacity, generating process steam (KP-5);

- steam boiler house of 1.3 MW (KP-8), generating steam to be used by the laundry;

- water boiler house of 6.6 MW (KWT), working for ventilation and air conditioning purposes - working also as a reserve source.

To ensure a reliable heat supply, the boiler house was installed with dual fuel (oil/gas) capabilities.

\subsubsection{Project Implementation}

Modernization of the heating system in the Children's Hospital was an investment carried out by MPEC. U.S. funds were used for the planning and design work. U.S. funds were also used to purchase some of the required equipment, including:

- preinsulated pipes;

- compact heat exchanger nodes;

- equipment for gas boiler house.

Construction and assembly work and the purchase of the basic equipment for the gasfired boiler house were financed by MPEC. The financing provided by MPEC was subsidized by funds provided by the EcoFund and the Gmina Fund for the Environmental Protection and Water Management. Due to a requirement that the work be done without disturbing the hospital's normal operation it was nccessary to do the work in stages. The schedule of project's implementation was as follows:

July-September 1999

November 1999-Feb.2000 March-August 2000

September -November 2000

September-November 2000

August-December 2000 August 2000-January 2001
Design the KP-5 boiler house and obtain building permits.

Construct the KP-5 steam gas boiler house. Design the KP-8, and KWT boiler houses, heating, network, and compact heat exchanger nodes.

Replace the heat exchanger nodes.

Construct the heating network at hospital's premises.

Construct the KP-8 steam boiler house.

Construct the KWT water boiler house. 
December 2000

June-July 2001
Shut down the Biezanów boiler house.

Construct the junction of Southern main line with the process network in a region of K XVII

The completed project will allow for the elimination of the process boiler house. This boiler house had a total capacity of $17.5 \mathrm{MW}$ and used around 10,000 metric tons of fine coal per year.

\subsection{Elimination of Coal Stoves}

\subsubsection{Description of the Current Status}

The objective of the program was to decrease the number of coal-fired home stoves by converting them to electric heating. The effort was directed toward those areas with the highest concentration of coal-fired house stoves, specifically, the city center. Coal stoves are the source of pollutants released into the atmosphere that are particularly harmful to the surrounding neighborhood. Earlier projects in this program considered the possibility of reducing emissions from coal stoves by replacing coal with smokeless briquettes. This course of action was not successful, however, because the attempts to manufacture inexpensive, quality briquettes on a market scale failed. The low rate of replacing coalfired home stoves is mainly due to:

- the lack of a sufficient number of transformer substations within the city center to which customers can be connected to;

- the unresolved legal status of buildings;

- the inability to clearly define building ownership, which hinders obtaining investors;

- building owners' lack of funds and their reluctance to invest, considering low revenues brought by buildings.

The Municipality of Cracow, through the agency of the Municipal Fund for Environmental Protection and Water Management (GFOŚiGW), provided support for converting coal-fired stoves by granting subsidies to residents. According to the up-dated survey, there were 77,800 functioning coal-fired stoves at the end of 1999 , including:

- 2,200 - within the $1^{\text {st }}$ ring road;

- 26,730 - between the $1^{\text {st }}$ and the $2^{\text {nd }}$ ring road;

- 48,870 - between the $2^{\text {nd }}$ ring road and the city limits.

The number of stoves between the $1^{\text {st }}$ and $2^{\text {nd }}$ ring roads, broken up by individual quadrants is as follows:

- area I (eastern) - 3,185 stoves; 
- area II (southern) - 10,250 stoves;

- area III (western) -4,100 stoves;

- area IV (northern) - 5,235 stoves.

The highest concentration of coal-fired stoves is within the $1^{\text {st }}$ ring road and within the $2^{\text {nd }}$ ring road in areas neighboring the following streets:

Karmelicka - Pawlikowskiego - Kochanowskiego

Krupnicza - Loretańska - Studencka

Straszewskiego - Na Groblach Square - Powiśle

Stradom - Koletek

Stradom - Dietla

Dietla-Paulińska - Meiselsa - Brzozowa - Miodowa - Starowiślna

Św. Gertrudy - Sebastiana - Sarego - Bogusławskiego

Dietla (odd building numbers) - Wrzesińska

Sołtyka - Eazarza - Dwernickiego

Librowszczyzna - Zyblikiewicza - Wielopole

Radziwiłłowska - Westerplatte - Lubicz

Topolowa - Lubomirskiego

Szlak - Pędzichów - Krowoderska - Długa

Fenna - Biskupia - Lobzowska - Asnyka

In areas outside of the $2^{\text {nd }}$ ring road, which is an area of diverse land development, the highest number of stoves occurs in regions of Stare Podgórze, Lobzów, Nowa Wieś, Dębniki, Półwsie Zwierzynieckie.

The conversion of coal-fired to electric heating can be done in two ways: either by installing coils in ceramic stoves or by installing new storage type heaters. Due to the significant difference in the costs of these two options, the project chose to convert stoves by installing electric coils in existing stoves. The Municipality of Cracow, through the agency of the Municipal Fund for Environmental Protection and Water Management (GFOŚiGW), provided subsidies to residents to assist them in converting their stoves. The subsidy paid for about $20-30 \%$ of the cost of installing coils in existing stoves. In 1995-99 GFOŚiGW subsidized the conversion of 9,700 stoves.

\subsubsection{Scope of Work}

The conversion of coal stoves required technical, organizational, and financial support. Due to limited funds, the program was primarily focused on establishing a foundation for efficient procedures, and further, at directly supporting the conversion work. The scope of work included:

- identifying the ownership of land plots within the $1^{\text {st }}$ ring road;

- identifying 8 potential locations for transformer substations in this area;

- obtaining administrative approval for construction and land management; 
- preparing a plan to finance the implementation phase of the project;

- preparing technical documentation for constructing a transformer substation at 1 location (from among those previously identified) and for preparing an application for the construction permit.

\subsubsection{Project Implementation}

The schedule for implementation of the project was as follows:

\section{March 1999}

An agreement was signed between the Cracow Power Supply Utility S.A. (ZEK S.A.) and BRK providing for the construction of transformer substations to meet the needs generated by the conversion of coal-fired stoves to electric heating within the Cracow center. In accordance with the agreement's terms and conditions, the ZEK S.A. approved the proposed extension of the American-Polish Program for the Reduction of Low Emissions Sources and undertook to include the substations proposed by BRK in its investment plan. The Power Supply Utility pledged to allocate funds to the project that were at least equal to those provided by the American side.

October 1999 - January 2000

In order to identify potential sites for the location of transformer substations within the $1^{\text {st }}$ ring road, land ownership status was analyzed. For this purpose a geodetic study was prepared. From this, those privately-owned and predominantly privately-owned land plots were excluded if the owners would not consent to make land available for construction of a transformer sub-station, in spite of the small area needed for this purpose (about $10.0 \mathrm{sq} . \mathrm{m}$.). Within the $1^{\text {st }}$ ring road 304 land plots were identified and analyzed for transformer station location. The analysis covered:

- current status - transformer substations, $15 \mathrm{kV}$ lines;

- potential power consumption;

- types of transformer substations currently built;

- plot availability for construction work and station's operation;

- possibility of laying $15 \mathrm{kV}$ and low voltage cable lines

- assessment of the ZEK S.A. activity (begun in 1995); associated with construction of transformer substations within the $1^{\text {st }}$ ring road.

The analysis made it possible to identify land plots in the following 8 areas:

Szczepański Square - Reformacka Street

Nos. 3/5 Dominikańska Street

No. 5 Św. Marka Street

No. 18 Św. Krzyża Street - No. 3 Św. Ducha Square

$\mathrm{Na}$ Gródku Street - Św. Krzyża Street

No. 15 Szpitalna Street 
No. 4 Św. Krzyża Street

No. 16 Grzegórzecka Street

As a result of the analysis of ZEK S.A. data, several construction projects are planned in the city center in the near future. New transformer substations will be built as part of these projects, however all the power produced by these stations will be needed for use by the new buildings identified below and there will be no surplus power available for use by the converted stoves. These projects include:

- an office/hotel building at Św. Tomasza Street;

- a hotel at No. 4 Wielopole Street;

- an office/service building at Straszewskiego Street.

Refurbishment, reconstruction or construction of buildings is done by private investors who will not consent to locate on their plot or in their buildings transformer substation with a capacity sufficient for neighboring users.

\section{February-March 2000}

Having obtained the Power Distribution Utility's authorization to obtain an administrative decision specifying conditions for construction and land management, documents were prepared and applications filed with the Department of Architecture, Geodesy, and Building to obtain siting decisions for the substations. It was proposed that free-standing transformer substations be constructed on the proposed site. Applications for "DWZiZT" (decision on conditions of construction and land management) were prepared for 7 sites within the Planty park ring and for one site near Grzegórzecka, Sniadeckich, Blich, and Kopernika Streets. The applications were filed with the Cracow Municipal Office.

\section{February-April 2000}

In the $1^{\text {st }}$ ring road the Dominican Monastery, the owner of the plot at 3/5 Dominikńska Street, consented to have a transformer substation located on their premises. A building design/work schedule was prepared for a dual transformer substation $2 \times 630 \mathrm{~kW}$, including laying a medium voltage cable leading to the station and low-voltage distribution cables to buildings located at Nos. 1 and 3 Dominikańska Street. About 60\% of the designed substation's capacity will be used by the owner of the facility. The remainder will be used to convert stoves to electric heating in neighboring buildings

November 2000

As a result of the actions undertaken, four favorable siting decisions were obtained. For three other locations, favorable opinions of the Heritage Conservator were obtained. The Municipal Office is currently preparing siting decisions. In one case residents of neighboring buildings filed a protest against the proposed siting. The siting decisions that 
were obtained were passed to the Power Supply Utility, which has committed to implementing the project. 


\section{Effect of the Program Implementation}

\subsection{Reduction of Pollutant Emissions}

This Program has directly resulted in the implementation of over 300 capital projects, with the participation of firms from the United States and Poland. The total amount of funds committed in the Program exceeds US\$ 40 million. Another effect has been the development of a substantial base of engineering, legal, and organizational information. The Cracow Program provides a model for other Polish towns experiencing similar air pollution problems.

The most important tasks implemented under the Program are as follows:

- The development of engineering and organizational concepts for eliminating the sources of low emissions in the town, (included in the Implementation Plan);

- The elimination of 165 solid fuel-fired boiler houses with a combined capacity of 159.4 MW through connections to the municipal district heating systems;

- The elimination of 107 solid fuel-fired boiler houses with a combined capacity of 35.5 MW, through conversion to natural gas or fuel oil;

- The modernization of heat exchanger substations and the installation of automated control systems in two hospital facilities with a combined capacity of $20.7 \mathrm{MW}$;

- The installation of high-efficiency particulate control systems in two industrial boiler houses having a combined capacity of $7.5 \mathrm{MW}$;

- The installation of automatic combustion control systems in two housing estate boiler houses with a total capacity of $45.7 \mathrm{MW}$;

- The modernization of the central heating installations in 34 buildings in two housing Estates;

- The modernization of the heating system management of the Children's Hospital at Prokocim, and the elimination of a 17.5 MW boiler house associated with the hospital;

- The demonstration of low-cost measures for energy efficiency in 4 multi-apartment residential buildings;

- The creation of a possibility to extend the power supply system in five areas of Cracow and to eliminate ca. 800 home coal stoves by converting them to electric heating.

Environmental effects obtained through capital projects implemented under the Program are summarized in Table 6-1. 


\subsection{Program's Impact}

In the 1990's there were many actions undertaken in Cracow that resulted in a dramatic reduction of pollution from local sources. These activities, based on political and economic transformation that began in Poland in 1989 were either inspired or supported by the American Program. The following specific examples should be mentioned:

Table 6-1. Summary of Environmental Impacts

\begin{tabular}{|l|l|l|l|l|l|}
\hline \multirow{2}{*}{ Project } & \multicolumn{4}{|l|}{ Reduction of emissions } \\
\cline { 2 - 6 } & Particulates & $\mathrm{SO}_{2}$ & $\mathrm{NO}_{\mathbf{x}}$ & $\mathrm{CO}$ & $\begin{array}{l}\text { Equivalent } \\
\text { emissions }\end{array}$ \\
\cline { 2 - 6 } & $\mathrm{Mg} /$ year & $\mathrm{Mg} /$ year & $\mathrm{Mg} /$ year & $\mathrm{Mg} /$ year & $\mathrm{Mg} /$ year \\
\hline Shooshanian & 265.6 & 258.3 & 45.1 & 388.8 & 1353.7 \\
\hline Control Techtronics & 101.0 & 36.0 & -9.0 & 9.0 & 307.3 \\
\hline LSR & 22.8 & - & - & - & 66.1 \\
\hline Honeywell & 690.0 & 590.0 & 129.0 & 950.0 & 3440.0 \\
\hline Tecogen & 112.0 & 244.0 & 21.0 & 97.0 & 678.2 \\
\hline MPEC boiler house conversion 1998 & 39.7 & 21.6 & 1.7 & 55.9 & 169.7 \\
\hline 1999 boiler house conversion & 127.6 & 76.4 & 10.2 & 183.3 & 567.7 \\
\hline 2000 boiler house conversion & 230.3 & 231.7 & 61.8 & 415.7 & 1286.5 \\
\hline Children's Hospital & 168.6 & 128.0 & 36.3 & 99.5 & 772.2 \\
\hline Elimination of coal-fired home stoves & 13.6 & 7.6 & 0.7 & 68.0 & 83.0 \\
\hline Total & 1771.2 & 1593.5 & 296.8 & 2267.1 & 8724.5 \\
\hline
\end{tabular}

The total reduction in $\mathrm{CO}_{2}$ emissions due to all aspects of the program is estimated to be 67,645 metric tons per year.

\subsubsection{Program for Reconstruction and Modernization of the District Heating Network}

This program was implemented between 1991 and 1998 by MPEC in cooperation with the World Bank. The objective of the first stage was to eliminate or minimize losses incurred through water leakage and heat loss from the system. In the second stage, direct connections were replaced by heat exchangers, heat meters were installed at customers' connections, the whole system was automated and a monitoring and control system installed. One of the priorities of MPEC is the elimination of low emissions. Between 1991 and 1998 MPEC eliminated, through connection to the municipal system or conversion to gas, $293 \mathrm{coal} /$ coke boiler houses with a combined capacity of $232.8 \mathrm{MW}$.

\subsubsection{Program to Restrain the Decline in Thermal Energy Demand and to Reconstruct the Market of Cracow Heat and Power Plant S.A.}

At the beginning of 1990s, as a result of the economic slump and prices of energy being elevated to realistic levels, the demand for energy from Cracow Heat and Power Plant S.A. (ECKSA) decreased dramatically. A new competitor, the modernized Skawina Heat and Power Plant emerged in the market, capable of reaching still more remote parts of town with heat supplies. 
Natural gas became a commonly available energy medium in urban areas, as did fuel oil and propane. The loss of the market and the resulting increase in the share of fixed costs caused ECKSA to act dynamically in order to acquire new customers. Some 560 boiler houses using solid fuel, with a total capacity of $357 \mathrm{MW}$, were identified within the service area of ECKSA A package aimed at the owners of these facilities was prepared, offering them network and heat exchanger station construction in place of their current boiler houses. The offered package included preparing design documentation, handling the organization of capital project implementation in terms of engineering and legal solutions, and finding sources of financing for the project implementation. From 1994 to 1997, ECKSA eliminated, through connections to the district heating network, solid fuel-fired boilers in 116 sites, with a combined capacity of $85 \mathrm{MW}$.

New customers were also attracted in the process. These actions resulted in stemming the decline in capacity orders, and since 1997, allowed for the gradual reconstruction of the market. Since 1999, the offer of ECKSA was broadened by including the construction of natural gas-fired boiler houses, owned and operated by the company.

\subsubsection{Elimination of Boiler Houses by Private Owners}

Until the end of the 1980s, the main energy source had been solid fuel, mostly hard coal and coal

Number of solid fuel-fired boiler houses in Cracow

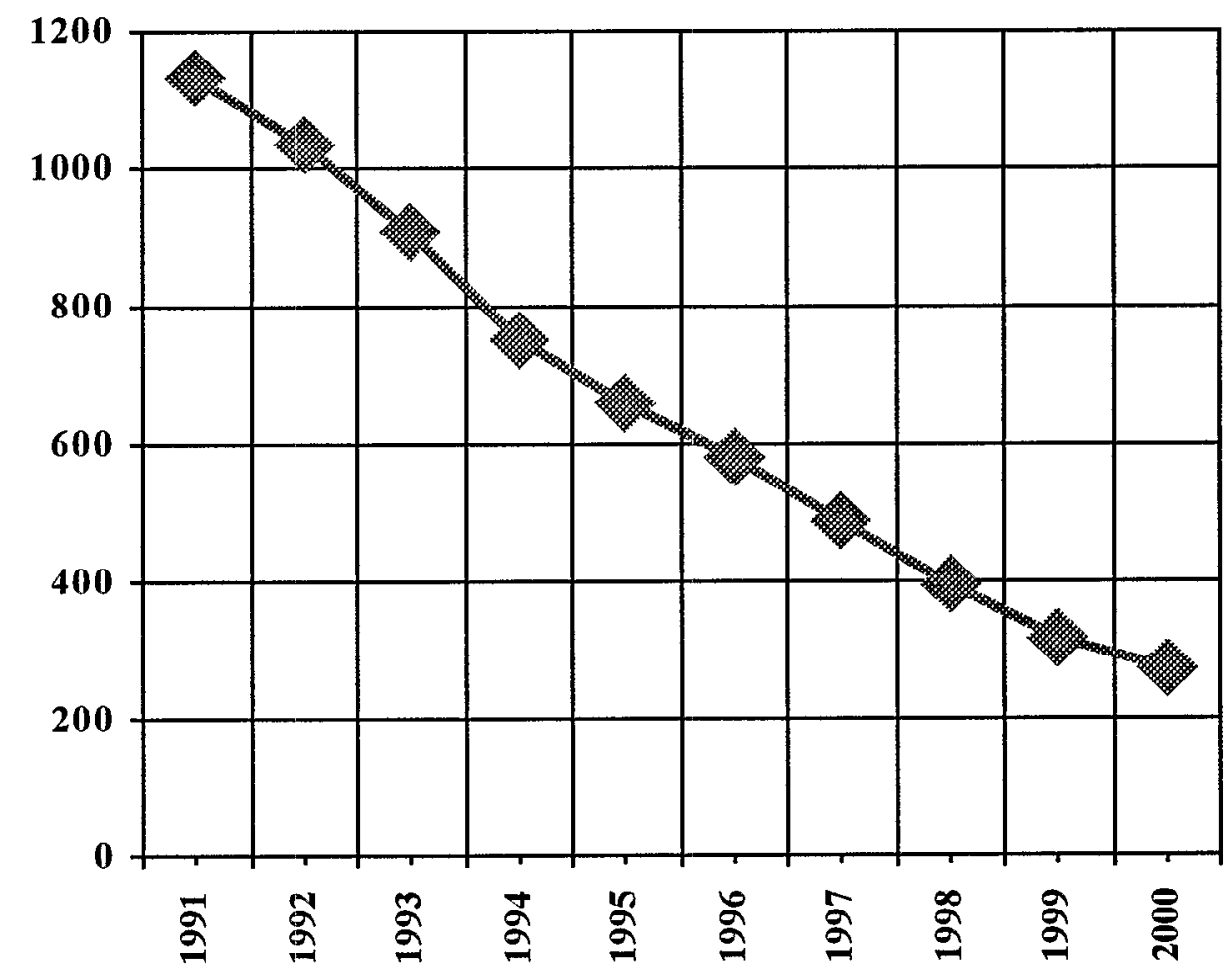

Figurc 6-1. Illustration of the elimination of solid fuel-fired boiler houses in Cracow over the term of this program. 
duff. The availability of coke and environmentally clean fuels such as natural gas had been limited by administrative measures. Boiler operators had to get special permits to use these premium fuels which were reserved for specific applications. In the 1990, natural gas became a commonly available energy medium, as did fuel oil, in the peripheral parts of the town. There is an increasing drive towards applying environmentally clean, easy to handle energy media, which do not require permanent operators. In the 1990, private owners eliminated over 300 coal and coke-fired boiler houses by converting them into gas-fired boilers.

\subsubsection{Activity of Environmental Protection Funds}

Environmental organizations operating in Poland contributed significantly to the implementation of the environmental projects in Cracow. EcoFund and the Voivodship Fund for Environmental Protection and Water Management co-financed the ECKSA project. EcoFund supports many capital projects of MPEC. In 1995-1999 the Municipal Fund for Environmental Protection and Water Management provided grants to individuals to eliminate 9,697 coal home stoves and 101 small boiler houses to various institutions to eliminate 85 boiler houses. Under the GEF (Global Environmental Facility) Program, the coke-fired boiler house at 2 Jana street, that supplies heat to the Cloth Hall and the City Hall Tower and other buildings, was converted to natural gas. The EAPS (Environmental Action Program Support), financed pre-design analyses for several dozen projects. The support from environmental funds in the form of either grants or soft loans permitted the implementation of capital projects with lower rates of return.

\subsubsection{Energy Conservation Programs}

The Energy Efficiency Demonstration Project under the energy-saving component of the Program, has proven that the energy conservation measures applied in buildings can result in savings in excess of $30 \%$ in terms of heating costs. Housing co-operative's building managers were able to obtain additional savings by installing additional insulation in the ceilings and external envelopes of buildings and fitting thermostatic valves and cost allocators, that significantly lower the consumption of energy and reduce heating bills.

\subsection{Improvement of Air Quality in Cracow}

In 1991, 1,133 solid fuel-fired boiler houses and approximately 100,000 coal fired home stoves were in operation in Cracow. The annual consumption of solid fuels was about 475,000 metric tons. With assistance from the President and Government of the United States efforts were initiated for the return of clear skies over Cracow. Owing to intensive efforts, the air quality in Cracow shows steady improvement. Quite dramatically, the number of boiler houses using solid fuel decreased by as much as $75 \%$. Less steep, only by $22 \%$, was the decrease in the number of coal-fired home stoves. The combined amount of solid fuel use dropped by about $70 \%$.

At the end of the 1980s, the mean annual concentration of suspended particulates was over 100 $\mu \mathrm{g} / \mathrm{m}^{3}$ which exceeded the permitted level by a factor of two (in the heating season - three times), whereas $\mathrm{SO}_{2}$ exceeded the permitted level as much as 3.5 times. Systematic measurements taken by the Voivodship Sanitary Inspectorate indicate steady improvement in air quality in Cracow. In $1989-98$, the mean annual concentrations of suspended particulates decreased by more than $50 \%$, 
stabilizing at a level below the permissible standard. In the heating season, the permissible concentrations levels are exceeded only slightly. In the same period, the mean annual concentration of $\mathrm{SO}_{2}$ dropped by almost $60 \%$, and in 1998 it reached a value lower than the permissible value for the first time ever. Also in the heating season, the concentrations of $\mathrm{SO}_{2}$ do not exceed the permissible value. Particularly noticeable is the reduction of air pollution in the center of town where the concentration of suspended particulates dropped by almost $60 \%$, and the concentration of $\mathrm{SO}_{2}$ dropped by $65 \%$. 


\section{Plans for the Future}

\subsection{State Environmental Policy in the Years: 1991-2000}

In the 1980's the air pollution level in Poland increased to extremely high levels, the highest in Europe. Poland contributed as much as $10 \%$ of the total $\mathrm{SO}_{2}$ emitted by all of the European countries and as much as $12.5 \%$ of emitted particulates. The highest emission levels were reported in the region of Upper Silesia, Walbrzych, Cracow and in the big industrial areas and all bigger cities.

The change of the political and economic system which occurred in Poland after 1989 was followed by a change of attitude toward environmental issues. In 1991 the Polish Parliament approved a document, "The State Environmental Policy". As a basis for this the principle of ecodevelopment was accepted. This calls for a balance between the needs and ambitions of the state and society and the environment. Such an understanding of the ecodevelopment rule should bring both social, environmental and economic benefits, compared to the present state.

In the area of environmental protection the most crucial tasks were started, which allowed Poland to make up quickly for the carelessness of many years. This included:

- increase of energy prices, so that energy conservation would be economically attractive;

- the introduction of tough standards for $\mathrm{SO}_{2}, \mathrm{NO}_{\mathrm{x}}$ and particulate emissions;

- the closure of old industrial plants hazardous to the environment;

- the construction of coal washing plants for the reduction of sulfur and ash content in coal and installations for flue gas desulfurization in heat and power plants;

- elimination of low emissions in the centers of big cities and in health resorts;

- reduction of greenhouse gas emissions which impact climate.

The change of the economic system was accompanied by a sharp decline in industrial production during the years $1989-91$ by more than $35 \%$. At the same time, though to a lesser degree, energy consumption was reduced (by around 25\%) and emissions of main atmospheric pollutants decreased (by around $25-33 \%$ ).

Starting in 1992 , industrial production began to grow, first slightly and then very rapidly. The growth of industrial production took place at a stabilized energy consumption level, lower by around $27 \%$ than in the year 1989 . Industry was modernized and the efficiency of energy use was improved. At the same time, significant emission reductions were achieved through investing in environmental protection equipment. As a result, the impact on the environment was reduced and air quality improved. In 1997 emission of $\mathrm{SO}_{2}$ was lower by around $48 \%$, emission of nitrogen oxides by $28 \%$ and emission of particulates by as much as $57 \%$ compared to the year 1988.

To enforce the agreements of "The State Environmental Policy", accepted by the Polish Parliament in 1991 several activities were undertaken: 
- New government organizations were formed -Ministry of the Environment, State Inspection of Environmental Protection;

- New legal regulations were adopted (among others: regulation on protection and forming of the environment, regulation on waste management, regulation on spatial planning, building law, energy law);

- A control system was established and enforcement of environmental protection law was improved;

- A system of financing and supporting environmental protection activities was established (National Fund for Environmental Protection and Water Management, Environmental Protection Bank, the EcoFund foundation, voivodship, county and gmina funds for environmental protection);

- Institutions were established with responsibility for promotion of pro-environmental and energy savings measures and for transfer of the technologies: Krajowa Agencja Poszanowania Energii (National Agency of Energy Conservation), Narodowa Fundacja Poszanowania Energii (National Foundation for Energy Conservation), Agencja Techniki i Technologii (Agency of Technique and Technology);

- Poland began to participate in international cooperation projects, and undertakes the commitments resulting from conventions and treaties.

Funds for environmental protection in Poland are increasing continuously. In 1991, they amounted to 0.8 billion USD. In 1998 they grew to as much as 2.8 billion USD (1.6\% of GDP).

In 1998, efforts on the development of a new state environmental policy were undertaken, which included previous achievements and formed new goals in the area of environmental protection and compensated development. The new environmental policy provides opportunities at two levels:

- Obtaining further improvement of environmental quality and proper factors in the area of efficient management of natural resources (low factors of energy, material and water use by the state economy) through the adopting and enforcing of the EEC standards in the environmental protection area;

- Obtaining more social and economic profits.

The leading rule of Poland's environmental policy is a principle of "compensated development," accepted by the Constitution of the Republic of Poland. For the first time this principle was defined in 1992, at the United Nations Conference in Rio. The basic assumption of compensated development is a policy of activities in specific sectors of economy and social life, so that environmental resources are preserved for the use of both present and future generations. The essence of compensated development is the equivalent treatment of the social, economic and 
environmental needs. This translates to the necessity to integrate environmental protection issues with the policy of specific branches of economy.

\subsection{Greater Participation of Society in Environmental Protection Policies}

On June 25, 1998 in Aarhus, during The Fourth Paneuropean Conference Of Environmental Protection Ministers, Poland signed the "Convention on the Availability of Information, Participation of Society in Decision Making and Access to Justice in Environmental Protection Cases". The convention defines the rights of society regarding environmental protection issues, particularly:

- Access to information;

- Participation in decision making policy;

- Access to administration of justice.

According to conference agreements access to information about the environment should be secured:

- With no necessity of any justification ("available to everyone");

- As soon as possible;

- At low cost.

The convention has imposed on public authorities the obligation to gather, update, compile and make available information including:

- Information on endangering situations

- Information on planned and implemented projects having impact on the environment;

- Reports on the environment;

- Texts of the legal acts;

- Policy guidelines, plans and programs;

- Environmental conventions, treaties and agreements.

Participation of society in decision making policy is governed differently in specific cases and in general cases as development of plans, programs, policy guidelines and legal acts. The Convention controls in a detailed way participation of society in decisions for specific projects. The Convention does not define procedures for society contribution in preparation of plans, programs, and policy guidelines, recommending only that:

- The time frame should allow for real participation;

- Information should be publicly available;

- There should be a possibility to express comments, which would be considered by decision makers.

As written, the convention emphasizes practical solutions and not legal guarantees. On January 1, 2001 a new law came into effect "The Law on the Availability of Information on the Environment, Protection of Environment and Assessment of the Environmental Impact" approved 
in November 2000. According to the law, necessary legal, organizational and financial solutions have been adopted aimed at establishing, in administration offices, an efficient system of providing and disseminating information and making possible effective participation of society in the protection of the environment. To facilitate information circulation to the greatest degree, an advanced method of communication will be used. The amount of information available on the administration's web sites will be increased. Public records will be developed, in which the following information on the area of environmental protection will be available for public inspection:

- decisions defining the type and quantity of pollutants allowed to be emitted;

- lists of types and quantities of pollutants emitted to the atmosphere;

- decisions on the assessment of fines and fees, delay of payment terms and installment payment of fines imposed for violation of the environmental requirements;

- decisions regarding applications on environmental impact assessments;

- reports on the environmental impact assessment;

- post-implementation analyses;

- lists with information on release and transfer of securities.

All environmental protection public records will be managed in the form of an electronic database which will be made available also electronically. Public review of drafts of standards, programs and policies and decisions will include the widest possible circle of potentially interested persons, organizations and institutions. To notify society and provide access to the drafts of documents, web pages and TV teletext pages will be used and electronic lists will be developed. Non-government environmental organizations will be supported by the government to conduct educational, informative or consultative activities focused on environmental protection and also organizations cooperating in the control and enforcement of environmental protection requirements and propagating environmental management systems.

\subsection{Cooperation of the Polish and American Companies}

In the 1990's, some of the American companies expanded their activity in Poland, based on the experience gained during the implementation of the U.S./Polish low emission program. This includes:

- Honeywell Inc.

- Johnson Controls

- Mestek Inc.

- LSR Technologies

Honeywell Inc.

Honeywell is a world leader in the area of automatic control systems and has been present in Poland since the 1960's. 
A Honeywell branch office was opened in Poland in 1990. At present, Honeywell ltd. has more than 100 employees in Poland, offices in 4 cities: Warsaw, Gdansk, Chorzów, and Wrocław and an extended network of partners throughout Poland. Honeywell is working in three basic areas:

1) Automatic control in industry - customers are mainly refineries, chemical plants and power plants (Gdansk Refinery, Plock Refinery, Chemical Works in Police, Nitrogen Works in Pulawy, Chemical Works in Oswiecim, Paper and Cellulose Works in Swiecie, Polaniec Powerplant).

2) Automatic control of houses and buildings - applied to hotels, hospitals, offices, supermarkets and also to heating networks in cities and residential areas. Honeywell's building control systems have been installed in the most representative hotels in Warsaw such as: Mariott, Sobieski, Victoria, in the hospitals in Lublin, and Trzebnica, in the complexes of offices and shopping centers like the Warsaw's Panorama, Elektroland in Janki, in the Office of Ministry Council and in the network of Pizza-Hut premises in the entire country.

3) Elements of automatic controls - these are microswitches, electromagnetic valves etc, provided mainly to Honeywell's partners, shipyards, manufacturers transportation facilities and manufacturers of machines. Customers are, among others: WSK Mielec, Nord in Gdansk - a supplier of electromagnetic valves to the Polish shipyards , Melex Vehicles Manufacture.

In April 2000 the European Bank of Reconstruction and Development signed with Honeywell an agreement for the amount of $\$ 25$ million dollars in connection with the promotion of energy saving technologies in the Middle and East European Countries. Honeywell has established, Honeywell ESCO Polska S.A. to provide services in the area of energy savings technologies in Poland. This ESCO, using its own financial resources will be modernizing sites with the use of energy efficient technologies and the investment costs will be paid back from the savings.

\section{Johnson Controls International}

Johnson Controls is a company with a global reach and 287 branch offices in 84 countries world wide. Activity of this concern includes two basic groups: control systems and automation systems. The Polish branch of Johnson Controls has been providing a complete set of technical and commercial services since 1990. At present, the company has 4 branch offices in Warsaw, Cracow, Poznan, and Gdansk. The Polish branches are focused mainly on control systems for large buildings. Controls are installed in the heating, ventilation, air-conditioning, lighting, firealarm and anti-burglar systems. The buildings are equipped with integrated computer management systems.

The range of the company's activity includes:

- preparation of technical documentation;

- supply of equipment; 
- supply of control panels and supply panels;

- installation;

- system start-up;

- warranty and post-warranty services.

The most noteable sites in Warsaw equipped with Johnson Controls systems are: Center of Air Traffic Control, Pulawska Financial Center, Reform Plaza, Warsaw Daewoo Plaza, Philips Company House.

\section{Mestek Inc.}

Mestek Inc. is a boiler manufacturing company which produces Smith and Hydrotherm water and steam boilers with Powerflame burners. Mostostal Panel Company Sp z o.o. represents Mestek Inc. in Poland. Mostostal Panel Company is also a representative of Cleaver Brooks, the American manufacturer of high pressure water and steam industrial boilers.

Mostostal Panel Company also provides "turn-key" investment services especially for the food industry. In 1990-1999 the company completed over 30 large projects in Poland. Mostostal Panel Company supplied American Smith type boilers for 75 gas boiler houses constructed as part of this program. Mostostol is affiliated with ABT Engineering in Chicago, $\mathbb{L}$.

\section{LSR Technologies}

In 1993, LSR started cooperation with the Polish company Eco Instal, a manufacturer of air protection equipment. LSR supplied Eco Instal with the technology of manufacturing and installation of core separators. Under this program LSR and Eco Instal have installed core separators at two sites in Cracow: KZA "Armatura" and MPK ul. Makuszynskiego

The rate at which core separators have been installed at sites throughout Poland is very impressive. Details have been provided in Section 3.4.

Eco Instal is continuing their commercial activities on introducing and installing core separators on the Polish market. As a result of the development activities related to core separators the employment in Eco Instal has increased from 30 to 100 employees. In 1997, Eco Instal received an award from the Minister of Environmental Protection "Leader of the Polish Ecology", mainly thanks to sale of core separators.

\subsection{Continuation of Activities in Cracow}

A resolution approved by the Cracow City Council in October, 2000 on the "Strategy of Cracow Development" established the following highest priorities for the area of environmental protection:

- reduction of low emissions from burning coal in home stoves and local boiler houses through successive elimination of solid fuels (replacement by gas, oil, or electric heating or connection to the district heating system); 
- efforts aimed at the reduction of emissions from industrial sources which are deemed very hazardous for the environment;

- reduction of traffic emissions;

- reduction of heat use by customers through implementation of energy saving programs.

The tools for achieving the above objectives are:

- use of "Energy Law" resolutions so to introduce competition to the energy market;

- decisions on the permissible emissions from specific sites;

- use of the EEC assistance funds and other funds (EcoFund, Voivodship and Gmina Funds for Environmental Protection and Water Management);

- an act on the support of building energy efficiency projects;

- MPEC S.A. ESCO activities in Cracow.

The City of Cracow has undertaken several activities in this area. A draft plan has been developed for the supply of heat, electricity and gas. A plan of compensated development and environmental protection is currently under development, which will define a strategy of the city for implementation of the environmental policy. To implement energy efficiency programs in buildings, an Energy Saving Company ESCO has been formed. A program of lighting modernization is being carried out. The Malopolska Agency of Energy Saving and Environmental Protection, which will be responsible for initiation and implementation of energy efficiency and environmental protection programs has been established.

Framework of a plan of heat, electricity and gas supply

The draft framework for a plan of heat, electricity and gas fuels supply is based on the following elements:

- description and evaluation of the existing systems: heating, power engineering, and gas systems;

- balances of heat, electricity and gas demands;

- forecast for heat, electricity and gas demands up to the year 2020;

- proposals of projects promoting the rational use of energy;

- proposals for using the existing surpluses and local supplies of energy;

- development of a concept for the modernization and development of the municipal infrastructure;

- range of cooperation with the neighboring cities.

The study has defined the scope and main directions of the city's infrastructure extension and analyzed environmental and economic results of the proposed activities.

According to a concept of heat supply, up to the year 2020, solid fuel fired boiler houses are expected to be eliminated through the conversion to gas ( $70-80 \%$ of the boiler houses capacity) or through connection to the district heating system (20-30\%). Home stoves will be in part replaced by the electric heating (15-20\% of stoves), gas heating (47-59\%), or connections to the district heating system $(1-3 \%)$. Part of the stoves will remained unused or will be eliminated with no replacement $(30 \%)$. Coal home heating systems (central boilers in detached homes) will be 
replaced by gas heating. Elimination of solid fuels in the inefficient and highly polluting local boiler houses and home stoves will climinate almost entirely the emission of $\mathrm{CO}$ and significantly reduce emission of particulates. Despite a regular reduction of emissions from central sources (EC Kraków, EC Skawina, HTS Power Plant) they will still have a dominant impact on the amount of emissions in Cracow. The forecast emission reduction up to the year 2020 will be: particulates $-57 \%, \mathrm{SO}_{2}-24 \%, \mathrm{NO}_{\mathrm{x}}-21 \%, \mathrm{CO}-96 \%$.

\section{Program of compensated development and environmental protection}

The program will consists of 2 parts:

1) long term strategy of compensated development in the years 2001-2020;

2) environmental protection program for the years 2001-2005 with a list of priorities.

The longer term strategy will include definition of major threats, criteria and standards of compensated development, compiling of a list of particularly important projects and their priorities, identification of engineering and economic solutions and rules of funding, defining the rules of environmental protection, information flow and cooperation between environmental protection services in the city and voivodship area. The short term environmental protection program will include a list of investments and projects aimed at environmental protection, including their priorities, cost estimation, funding sources and rules of program implementation supervision. It will also define possibilities of the self governing organizations impact on the environment through administrative, investment, informational and educational activities.

The program will be prepared with consideration of the rule of society participation in environmental policy. Possibilities will be created for citizens, social groups and non government organizations to participate in the process of forming the model of the city's compensated development with a simultaneous development of environmental education, arousing the environmental awareness and responsiveness, and forming a new ethics of environmental behavior. During implementation of the order, consideration will be given to recommendations resulting from the "Convention on the Availability of Information, Participation of Society in Decision Making and the Access to Justice in Environmental Protection Cases."

\section{Malopolska Agency for Energy and Environment}

Establishment of the Malopolska Agency of Energy and Environment effectively implements the concept of compensated development in the Malopolska Region and City of Cracow through the initiation and implementation of programs supporting environmental protection and energy conservation and also raising funds for implementation of these programs. Malopolska Agency of Energy and Environment (MAES) is a limited liability company whose shareholders are: The City of Cracow, Marshal Office and Society of Malopolski Gminas and County's. The agency was established in the year 2000. Its activity is co-financed from the "SAVE II" program and the European Union. MAES has been established on the basis of more and more interest of the local authorities and society in the rationale use of energy resources, which are at our disposal and for which we are paying. The company is undertaking activities in the area of public utility aimed at energy conservation and environmental protection: 


\section{Promotional activities:}

- energy conservation and environmental protection;

- promotion of energy saving building technology;

- promotion of renewable energy sources;

- organization of projects and demonstration programs.

Training activities:

- training in the area of energy conservation and environmental protection;

- organization of conferences;

- publishing activity.

Service activities:

- consulting and advisory services in the area of energy conservation and environmental protection;

- services in the area of energy plan development and local energy policy;

- services in the area of industrial and building audits;

- support in the preparation of applications for funding energy programs and environmental protection;

- energy conservation measures in buildings.

- The expected effects of the Agency's activities leading to reduction of energy use and improvement in the environment are:

- reduction of costs of heating and electricity in the buildings belonging to Gmina Cracow. and to the Malopolski Marshal Office;

- reduction of costs of heating and electricity in communal, housing cooperative and private buildings;

- development of regional programs and projects regarding energy and environmental protection improvement in power production;

- increase of the financial stream for investments connected with energy and environmental protection;

- reduction of emissions of pollutants (discharge of Poland's commitments regarding reduction of pollutants emission);

- increase of region's investment attractiveness;

- increase of industry competitiveness.

\section{Program of the lighting modernization}

Modernization of the lighting system in the area of Cracow City was carried out during 1998 and 1999. Investment was implemented in the form of an ESCO, and modernization included around $80 \%$ of the lighting points. Excluded from this modernization effort was the following: 
- historical zone (modernization will be carried out as a separate task);

- lighting of the streets which were previously reconstructed;

- lighting of the streets which are planned to be reconstructed (modernization will be carried out within the reconstruction scope).

A total of 48,725 new lighting points were installed in the city. Modernized were 38,125 lighting points. The total capacity of the lighting system before modernization was $11,200 \mathrm{~kW}$. The modernization program covered lighting equipment of $9,014 \mathrm{~kW}$ capacity. After modernization the capacity is $6,617 \mathrm{~kW}$. Within the modernization program light sources and lamp sockets were replaced and poles and extension arms were reconstructed. Seven-hundred and sixty-seven (767) control-supply boxes were replaced. The uniform system of lighting control with the use of sunlight meters was introduced.

As a result of using the energy efficient lighting sources, total lighting energy use was reduced by around $40 \%$. The investment cost will pay back in 6 years.

Energy Saving Company ESCO

Energy Saving Company ESCO, a company with a limited liability was established in April 2000 and is owned $100 \%$ by the Municipal District Heating Company (MPEC S.A.) in Cracow. Establishment of the ESCO is the result of several years of experience of MPEC S.A. in the implementation of energy saving projects and cooperation with the World Bank. The company is providing complex services in the energy management area. ESCO makes a commitment to finance modernization works. After modernization the cost of energy is reduced. A customer, during an agreed time period, is paying for the energy at the same price level as before modernization, and the savings are used to reimburse the investment cost born by ESCO. The payback time of the investment cost depends on the range of investment, amount of capital cost and the obtained savings. After the end of the contract a customer takes possession of the installed equipment. A typical cycle for ESCO services is as follows:

- contract signing;

- preparation of the conceptual design;

- development of the energy audit which defines the scope of modernization, results and payback time;

- implementation of the investment;

- training of the customer's technical personnel;

- operation of the installed equipment;

- monitoring of energy use;

- correction of operational errors;

- after end of the contract, the installed equipment and installation are delivered to the site's owner.

Benefits from using the ESCO include:

- no capital investment by the site owner; 
- investment does not require any knowledge and experience on the part of site owner;

- risk of the investment is taken by the ESCO company;

- improvement of comfort and reliability of energy supply follows very quickly.

\section{Energy Conservation Program for Gmina Buildings}

The management of Cracow City has approved the assumptions of the Energy Conservation Program for Gmina Buildings by a resolution issued on March 2, 2000. It is planned to cover with this program, in 2001-2006, around 500 sites belonging to the city. The program will be implemented using an ESCO formula service. Site qualification for the program and determination of implementation sequence will be done based on the following criteria:

- particularly high current costs;

- bad technical condition of the site's technical infrastructure;

- non ecological (coal or other fuel) supply source.

It is expected that after energy conservation measures the cost of energy consumption in these sites and cost of conservation of equipment will be reduced by $20-30 \%$.

\subsection{Programs in the other parts of Poland}

\section{Silesia}

The Voivodship Fund for Environmental Protection and Water Management in Katowice launched on August 1, 2000 a Pilot Program for Environmental Protection for the region of the Silesian Voivodship. Within this program the Voivodship Fund plans to allocate 10 million $\mathrm{zl}$ in the form of credits and partial subsidies as assistance for investments aimed at low emission sources.

The objective of the pilot program is to collect experience before commencing the program on a large scale. To implement this program the Voivodship Fund will be seeking support from the World Bank and the European financial institutions. The program's basic objective is the improvement of air quality, especially ambient particulates, which have very significant health effects. The goal is to reduce the concentration of pollutants in the Katowice region to the requirements of the European Union.

The pilot program's rules have been established based on, "Assumptions for the Program of Low Emission Reduction in the Region of the Silesian Voivodship", developed in 1999 through the Institute of the Chemical Processing of Coal, The Research and Control Center for the Environment, and the Main Institute of Mining. The "Assumptions..." were accepted by the Management of the Silesian Voivodship in March 2000. The objective of the pilot program is to define the possibilities and conditions on which the Silesian Marshal Office, Voivodship Fund and gminas will implement the program especially:

- Define the demand for modernization of the heating installation among the people of voivodship and public institutions;

- Estimate average costs and the level of emission reduction per apartment or house; 
- Define the possibilities of obtaining financial resources by the residents and gminas in the form of credits including the amount of resources and conditions on which they will be made available;

- Test the procedures connected with allocation of the financial resources.

It is planned to carry out public surveys to evaluate demand and public acceptance of the proposed activities, analyses of the communal housing resources and the policy of local government in managing the air quality. The pilot program is aimed at owners of home stoves and small boiler houses, which are used in houses, schools and hospitals. Investors have several possibilities to reduce emission from coal firing equipment: use of more efficient coal burning technology; conversion to gas, oil or electric heating; or connection to the local heat network. Financial assistance will also be provided in a case of modernization of heating systems and building insulation. In the pilot stage the Voivodship Fund will make available its financial resources in two components:

- Program of Small Loans - intended for natural persons and small enterprises from the area of the entire Silesian Voivodship.

- Program of Loans and Subsidies for Gminas participating in the pilot program and the other units from the area of gminas included in the program.

Within the Program of Small Loans credits will be allocated through the Environmental Protection Bank and Bank Przemysłowo Handlowy divisions. It is expected that the Voivodship Fund will make available financial resources which will allow around 500 preferential loans to be granted for private citizens and small enterprises.

\section{Wroclaw}

In 1998 MPEC Wroclaw SA - the local district heat utility has developed a program entitled "Elimination of Low Emission and Optimization of the Heating System in Wroclaw". The program consists of the following tasks:

- modernization of the heating network;

- modernization of the heating nodes;

- development of the control and monitoring of the heating system;

- construction of the heating network in place of the eliminated, outdated local boiler houses;

- cleaning of the main lines;

- extension of the heating system.

The length of the entire Wroclaw heating network is $434.5 \mathrm{~km}$, including $418 \mathrm{~km}$ which belong to MPEC Wroclaw SA (44.4 km constructed from preinsulated pipes). Under the program, modernization of $194.4 \mathrm{~km}$ of heating network is planned including $23.1 \mathrm{~km}$ which has already been completed. In Wroclaw's heating system there are 4486 heating nodes. MPEC Wroclaw SA operates 3483 heating nodes. The project assumes modernization of 2413 heating nodes, up till now have been modernized. Under the project elimination of the local, solid fuel fired boiler houses and home stoves was planned. They have a crucial impact on the status of local pollution, 
especially in the central part of Wroclaw, where the building density is high. Under the program climination of 50 local boiler houses is planned. In 1999, 19 boiler houses were closed.

The MPEC Wroclaw SA program has been co-financed through the following organizations: National Fund for Environmental Protection and Water Management, EcoFund, PHARE Fund, the World Bank, the Voivodship Fund of Environmental Protection, and Water Management in Wroclaw.

In the future MPEC Wroclaw SA will continue this work and will also be involved in the municipal program entitled "Thermomodernization of the Buildings and Elimination of the Home Firing Equipment". The structure of heat supply in Wrocław is as follows: $55 \%$ of the heat is provided from the central sources, $32 \%$ is produced by the local coal-coke boiler houses and tile stoves, $8 \%$ comes from larger boiler houses and gas heating and the remaining $5 \%$ comes from the other heat sources, e.g. electric energy. As a result of preliminary analysis 10 regions have been selected, in which the main heating source is coal stoves. An important part of the city is called Przedmiescie Olawskie, where the majority of the old, mainly communal, low standard buildings exist with low efficiency $(30-40 \%)$ coal stoves (waste material is used as a fuel). In this area air quality is very poor. In 200 selected houses there are around 12 thousand tile stoves. All research proves that coal stoves in which different type of waste material is often burned are the main reason of air pollution. The results of analyses prove that in the heating season the concentration of pollutants is as much as 10 times higher than during the summer season. The scope of work planned includes: connection of buildings to heating nodes, construction of connecting pipes for hot and cold water, building energy conservation projects, and elimination of the local boiler houses. To do these projects, it is necessary to obtain the owner's agreement, building permits, and agreement from the Monument's Keeper. In connection with the long term procedure of obtaining building permits, it is planned to modernize 3-6 pilot buildings in the year 2000.

The program is to be financed by MPEC Wroclaw, ZEC Kogeneracja - as a main partner, ISPA funds, credits (European Bank of Reconstruction and Development), the World Bank, and The European Investment Bank. Implementation of this program will have a direct impact on the improvement of living conditions and a reduction of air pollution in Wroclaw.

\section{Bytom}

Bytom Management and City Council have made a decision to prepare a long term program of improvement of the environmental state. "Master Plan of Environmental Protection in Bytom", a city Master Plan, accepted in 1995 includes strategies for the protection and management of the environment for the next 30 years (1995-2025).

The Plan takes into consideration coordinated policy in three areas: economic policy, social policy, and environmental policy. The intention of the Implementation Plan was to find a solution common to all three areas, though priority was given to environmental policy. During implementation of the Master Plan, several programs were initiated aimed at reducing atmospheric air pollution. Special attention must be given to: 
- "Program of Refunding and Modernization of the Housing Heating Systems" - This program covers apartments and homes. It is financed from the resources of the Gmina Fund for Environmental Protection and Water Management, which is derived from the charges and penalties for the use of environment. One-thousand six-hundred fifty-two (1652) applicants received funding by the end of 1997.

- "Program of Heating Modernization in the Educational Posts" - Thanks to this program coal heating was eliminated in more than 60 schools and nurseries in Bytom.

The above programs have brought measurable benefits for the city's environment - over 12 thousand metric tons of coal per year was eliminated from use. As a result, the emissions of such pollutants as particulates, $\mathrm{SO}_{2}, \mathrm{CO}$, and organics have been considerably reduced.

\section{Radom}

The most important project implemented in Radom is titled the "Pilot Project of the National Program." This project has been recognized by the organizers of the World Exposition EXPO2000 in Hannover as the best in the world. The Expo organizers have concluded that the project of Radom and the enforcement strategy are the best examples of practical use of the rule of compensated development among the 513 completed, similar projects. The Random environmental community has agreed with the use of health and environmental risk analysis with five environmental priorities: decrease of the level of ground water pollution and reduction of uncontrolled run-off, traffic air pollution, pollution of surface waters and sewage management, solid municipal waste, industrial and hazardous waste, and upgrading of parks.

It is not the only distinction for Radom for pro-environmental achievements. In the competition "The Cities in Compliance with the European Union Requirements" organized under the auspices of the European Union Regional Center for Environmental Protection for Eastern and Central Europe, Radom was awarded with a distinction for water management. Thereby the city positioned itself at the strict forefront of the 15 cities of Central and Eastern Europe, which comply with the requirements of the union environmental standards. In the competition, achievements of 230 cities were evaluated in such fields as air and water protection and municipal waste management. In October 2000, Radom received an award from the Voivodship Fund of Environmental Protection and Water Management "Friendly to Environment" for proenvironmental activities and investments. Radom is also a prize winner of a competition "The City for the Benefit of Consolidation with the Union - Award 2000", organized by General Directorate for Natural Environment of the European Commission

\section{Demonstration Project of low cost methods of the heating energy efficiency in the buildings.}

The Foundation for the Efficient Use of Energy in Krakow with support from the Association of Gminas, Polish Network and "Energie Cites", implemented a U.S. AID project on heating energy efficiency in buildings between October 1997 and August 2000. This project is aimed specifically at the case of limited financial resources for energy efficient investments. The objective of the project was demonstration of low cost methods of heat saving in buildings and consolidation of the local implementation potential of companies providing services in this field. The project included six towns: Krapkowice, Olsztynek, Nowy Sacz, Luban, Trzcianke and 
Bialystok. Within this project demonstration energy conservation projects were completed in five multifamily residential buildings and seven public utility buildings, obtaining large energy savings at low investment costs.

Efficient, low cost measures which provide total savings of around a dozen or so percent include:

- modernization and weatherization of windows and doors;

- insulation of the attic over the top floor;

- insulation of the external walls (advised by energy audit), especially up to the third floor;

- installation of automatic controls;

- installation of reflective insulators behind the radiators;

- elimination of unnecessary glass panels.

The project was funded by the American Agency for International Development U.S. AID, Global Environmental Facility and, on the Polish side, the Association of Gminas. 


\section{Summary Statement}

On July 10, 1989, President George Bush addressed the Polish National Assembly in Warsaw. Some excerpts from that address are provided here:

"Chairman Jaruzelski, Marshalls Kozakiewicz and Stelmachowski, Prime Minister Rakowski, and senators and delegates, on behalf of the people of the United States, I am honored to greet the newly elected representatives of the Polish Parliament. To be here with you on this occasion is proof that we live in extraordinary, indeed, thrilling times."

"Poland and the United States are bound, it is often said, by ties of kinship and culture. But our peoples are linked by more than sentiment. The May $3 d$ Constitution of 1791 set Poland ahead of her peers, ahead of her time, in the pursuit of freedom and democratic ideas, just as our Constitution, the American Constitution of 1787, set new standards for protection of the rights of the individual. For decades, beginning with the Versailles Peace Conference, the United States has stood for Polish independence, freedom, prosperity. And we are proud of our early and longstanding commitment to Polish selfdetermination. As America's President, I am here today to reaffirm that proud commitment."

"The future beckons with both hope and uncertainty. Poland and Hungary find themselves at a crossroads. Each has started down its own road to reform, without guarantee of easy success. The people of these nations and the courage of their leaders command our admiration. The way is hard; but the moment is right, both internally and internationally, for Poland to walk its own path. On the day Solidarity was restored, I spoke of my support and admiration for the political experiment just getting underway in Poland. You've since proceeded further along that road, including holding the remarkable elections that produced this Parliament. And let us consider what your experiment may mean not just for Poland but for Europe and for the entire world."

"There is great interest and excitement in the United States about what you're doing in Poland and a clear-cut desire to help the reform process. I hosted a White House symposium on July 6th to bring together citizens of my country interested in promoting investment, trade, and academic exchange with Poland and Hungary. And I can assure you that, more than ever before, the American people will be involved in your democratic experiment."

"....economic progress should not come at the expense of our common heritage, our common inheritance -- the environment. In fact, sound ecology and a strong economy can and must coexist. Air and water pollution know no boundaries, and this concern is worldwide. Almost 2 years ago, I visited Krakow, your former royal capital, a city recognized by UNESCO as an international treasure. Today Krakow is under siege by pollution; its priceless monuments are being destroyed. Krakow must be reclaimed, and the United States will help. And I'll ask the Congress for $\$ 15$ million for a cooperative venture with Poland to help fight air and water pollution there." 
After President Bush left Poland and the U.S. Congress acted the responsibility for meeting this commitment fell to U.S. AID and the project participants chosen under their direction. This team had to deal with the reality of the magnitude of the problem, the economic constraints of this era, and the political factors in both Poland and the United States. This final program report documents the response of the U.S. team to the commitment made in 1989. While the obstacles were substantial the progress has been much faster than expected. Solid fuel-fired boilers in Cracow have been nearly eliminated and air quality has improved dramatically: The work addressing air pollution from low emission sources is being continued in other cities throughout Poland, Eastern Europe, and other parts of the world. This program stands as a model for these efforts. 


\section{APPENDIX I \\ MAJOR PROGRAM PUBLICATIONS}

Throughout this program there have been a large series of topical reports covering results of specific engineering studies, combustion tests, legal and financial studies, results of public opinion surveys, studies of specific option air quality impacts, and others. The total number of these reports is roughly 60 . All of these reports have not been published but may be obtained by contacting T. Butcher at Brookhaven National Laboratory at (631) 344-7916, or e-mail butcher@bnl.gov. In addition to these reports, there have been periodic large reports, conference papers and conference proceedings, which provide a great amount of detail. A list of these published reports is provided below.

1. Cracow Clean Fossil Fuels and Energy Efficiency Program Phase I Report, T. Butcher and B. Pierce, eds., BNL Report BNL-52479, June 1995.

2. Cracow Clean Fossil Fuels and Energy Efficiency Program - Progress Report, BNL Report 66391, October 1998.

3. Plzen Proceedings - Conference on Alternatives for Pollution Control from coalFired Low Emission Sources, Plzen Czech Republic, April 26-28, 1994, U.S. Department of Energy Report CONF-9404166.

4. Proceedings - Krakow Conference on Low Emission Sources, October 10-12, 1995, Cracow Poland. Brookhaven National Laboratory Report BNL-52472.

5. Bieda, J., Bardel, J., Nedoma, J. and Pierce, B., Evaluating Home Heating Options in Krakow. ASHRAE Transactions 101 (1), 1995.

6. Wisnewski, R., Reeves, G., and Markiewic, J. EnergyPrice Incentives in a Planned Energy Economy. Proc. Of the ACEEE Summer Study on Energy Efficiency in Buildings, Pacific Grove, CA, August 28 - September 3, 1994. American Council for an Energy Efficient Economy.

7. Jaszczur, T., Lewandowski, M., Szewczyk, W., Zaczkowski, A., and Butcher, T., Coal-fired Tile Stoves-Efficiency and Emissions. ASHRAE Transactions 1995, V. 101, Pt.1 BNL Report BNL-62009.

8. Cyklis P., Kowalski, J., Kroll, J., Wlodkowski, A., Zaczkowski, A., Boron, J., and Butcher, T., Heating Boilers in Krakow, Poland: Options for Improving Efficiency and Reducing Emissions. ASHRAE Transactions 1995, Vol. 101 Pt. 1 BNL Report BNL-62010. 